\title{
José Andrés-Gallego
}
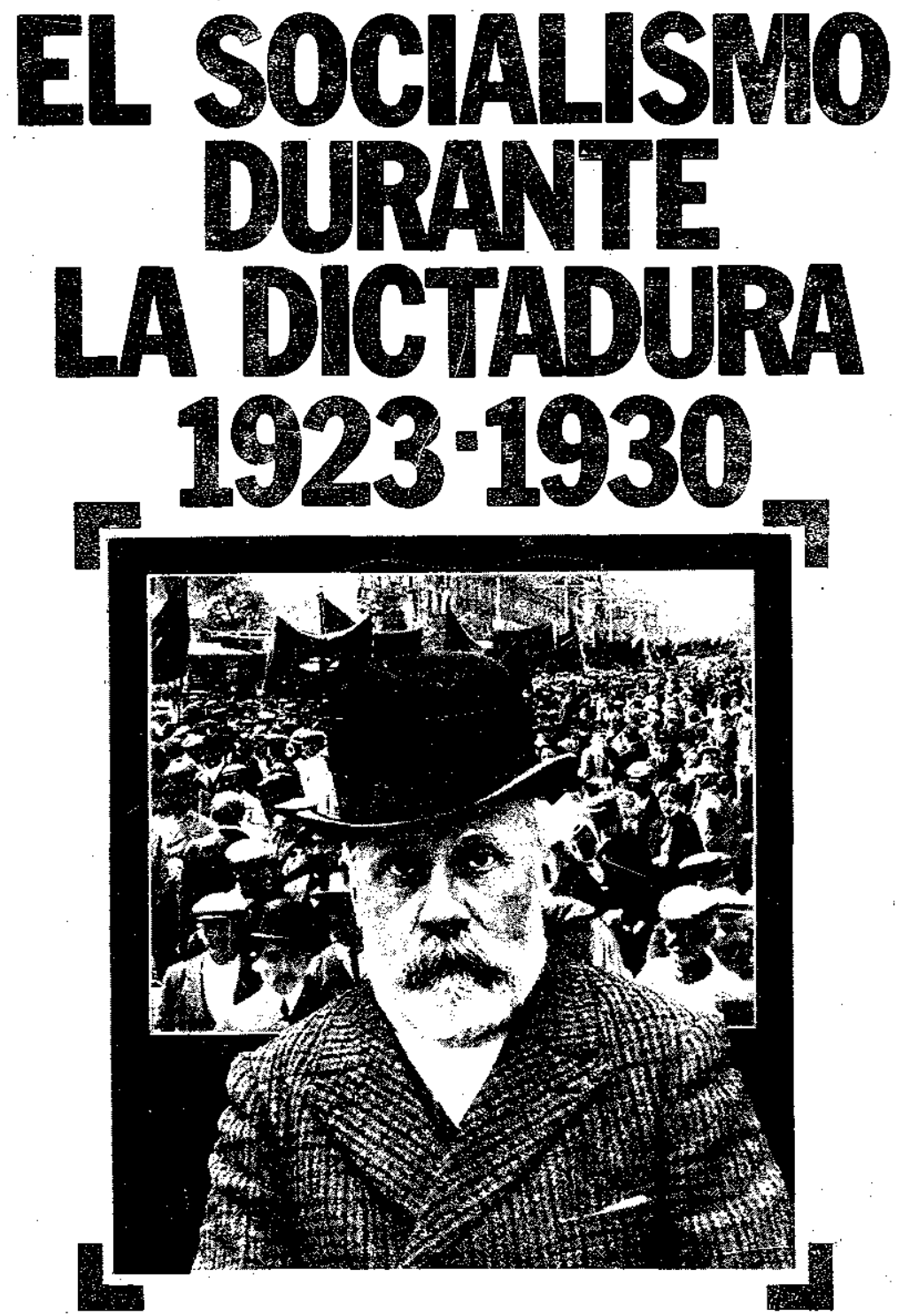


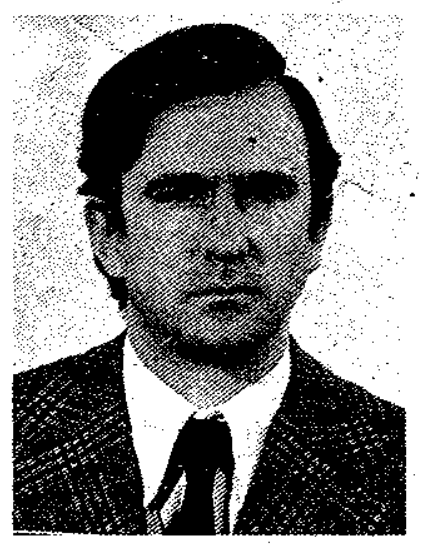

'José Andrés-Gallego es Catedrático de Historia Contemporánea de la U.N.E.D. nacido en Calatayud, tiene treinta y tres años. Ha dedicado toda su vida profesional a la docencia y a la investigación. Como docente, ha sido sucesivamente Profesor Agregado desde 1975 y Catedrático de Universidad ahora. Ha publicado varios libros. Entre ellos destaca su investigación sobre La política religiosa en España, 1889-1931 (Madrid, 1975) y la síntesis universitaria Historia del Mundo contemporáneo (Zaragoza, 1976), además de una treintena de estudios sobre la España contemporánea en distintas publicaciones especializadas.

ADVERTENCEIA SOBRE ESTA REIMPRESIÓN DE 2011

PREPARADA POR EL AUTOR (QUE AÚN VIVE)

Todo lo/précedente, en $1 \overline{9} 77$, cuando se imprimió en papel este libro. Fue la "lección magistral" (és un decir) çụe expuso el autor ante un tribunal que no lo hizo profesor agregado de universidad (dígo Profesor Agregado de Universidad). Eso vino después.

La idea da hablar de eso ante aquellos tribunos, se la dio Ignacio Olábarri, que podría haber escrito este libro con mucho más provecho para el mundo. Le pedí que aceptara la coautoría; pero no quiso. E hizo bien.

No se equivoquen con la foto. Una vez desprovisto del pelo de la dehesa, pero dotado de una timidez invencible, el autor intentó pasar desapercibido y se dejó barba para ocultarse. Pero, con los años, se fue poniendo blanca. Métanse en su página web y a ver si lo reconocen. Bueno, pues este libro también se ha puesto blanco con el tiempo; lo escribió en castellano académico de cuando los protagonistas no eran personas proletarias, sino "el proletariado", y eso dificulta la comprensión.

.Ustedes se dirán que, si no tiene mérito, por qué lo reedita (y en versión informática, que asegura sobremanera el éxito). Esa misma pregunta se la hizo un coopositor del que suscribe cuando reeditó su tesis doctoral. Y no se le ocurrió mejor cosa que confesar, en la presentación, que era muy deficiente, pero que la editaba tal como la había publicado en su día para que se supiera qué tesis tan impresentables se hacían en la Universidad franquista.

Tenía toda la razón, en su caso (digo en el caso de que la tuviese). Pero el autor de este otro libro lo reedita así porque no se siente con fuerzas para rehacerlo, dada la magnitud de lo que se ha añadido desde 1977 -muerto ya Franco- y habida cuenta de que está en otras guerras más pacíficas (no digo Franco -que también sino el autor) y que esa distracción no le compensa. Al fin y al cabo, espera que, a caballo regalado, no le miren el diente, claro está que sobre la base de que quien sirve al común sirve a ningún. 
EL SOCIALISMO DURANTE LA DICTADURA

(1923-1930) 


\section{José Andrés-Gallego}

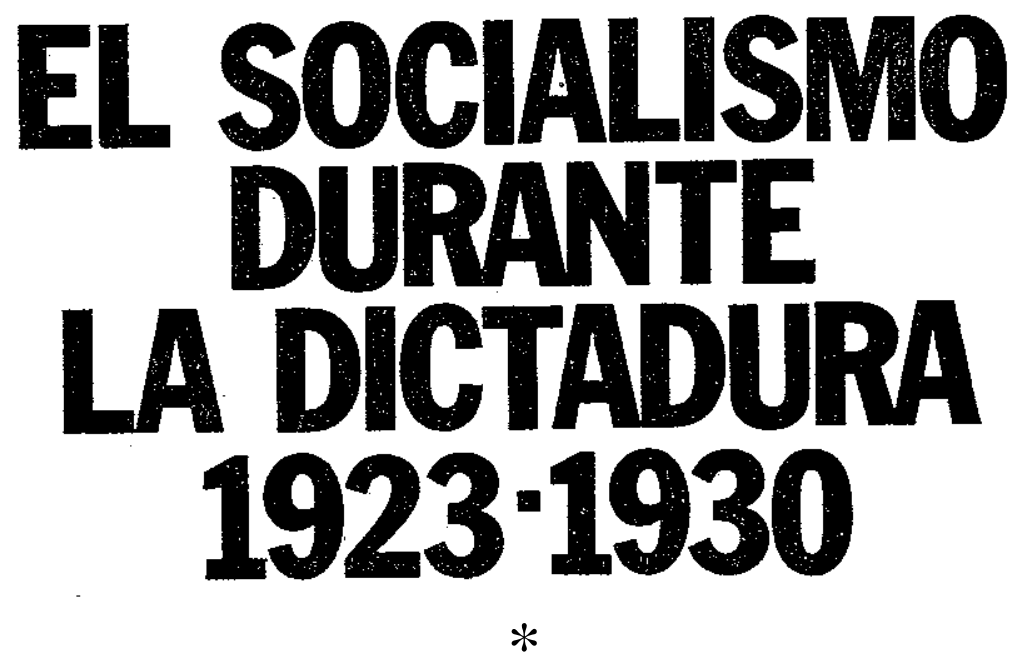

Apéndice documental

de

Ignacio Olábarri
y Antón M. Pazos

$*$

TEBAS

Fomento; 25:3? - MADRID:13 ;...... 
Coleccion: Historia Politica

(C) by José Andrés-Gallego y

EDICIONES GINRR - Caños, 7 - MADRID

Depósito legal: M. 40.992 - 1977

I.S.B.N. 84-7273-033-6

TORDEsIllas, ORganizactón Grárica - Sierra de Monchique, 25 - Madrid-18 


\section{NOTA DEL AUTOR}

Concebido en su origen como base de una lección universitaria, tiene este libro un doble fin: sintetizar lo que se ha escrito acerca del socialismo español en la Dictadura y contrastarlo con las fuentes impresas más relevantes de las propias organizaciones socialistas: la literatura política coetánea, la prensa y publicaciones oficiales del P.S.O.E. y la U.G.T.

En el estudio de esas fuentes ha sido inestimable la colaboración de los profesores Ignacio Olábarri Cortázar y Antonio Pazos Rodríguez, que han elaborado, además, un apéndice documental de evidente importancia. Ante todo recogen en él los principales textos oficiales y oficiosos emanados del Partido y la Unión General entre 1923 y 1930. E incluyen entre ellos una amplia selección de las actas - hoy de hallazgo difícil- de los Congresos ordinarios que celebran ambas asociaciones en 1928.

Vaya por fin mi agradecimiento a quienes por oficio fueron primeros jueces de las ideas aquí expuestas: Miguel Artola, José Manuel Cuenca, Vicente Palacio Atard, Federico Suárez y Mario Hernández Sánchez-Barba. 


\section{INTRODUCCION}

\section{Socialismo y dictadura en Europa ${ }^{1}$}

\subsection{LOS REGÍMENES AUTORITARIOS DE 1922-1939}

El estudio de la dinámica política de cada uno de los Estados de Occidente entre las dos guerras mundiales de nuestro siglo descubre un conjunto de rasgos comunes.

Uno de esos rasgos es la radicalización de los grupos contrarrevolucionarios.

En líneas generales, parece tratarse de una respuesta a las revoluciones socialistas y a los movimientos menores del período 1917-1921, que presencia el triunfo del bolchevismo en Rusia, la imposición del socialismo y el fracaso del espartaquismo en Alemania, el ensayo procomunista de Hungría, además de un sinfín de estallidos de alcance diverso en el resto del continente: la guerra civil finlandesa de 1918, los motines del año 17 en el Ejército francés, la propia huelga general española de ese año y la encrucijada social del 19 , entre otros acontecimientos ${ }^{2}$.

1 Recogen estas páginas iniciales las ideas ya expresadas sobre el tema en mi Historia del mundo contemporáneo, Zaragoza, Librería General, 1976, pág. 437 ss.

2. No existe - que yo sepa - una síntesis adecuada acerca de esta fase revolucionaria; aunque, de hecho, están contenidos los datos fundamentales en la de G. D. H. Cole: Historia del pensamiento socialista, t. V, 2." ed., Méjico, Fondo de Cultura Económica, 1964.

Si hay varias colecciones de estudios que de hecho también rompen la imagen de una revolución ceñida a Rusia, Alemania y Hungría, al presentar el eco de lo sucedido en estos países. Vid. sobre todo La Révolu. tion d'octobre et le mouvement ouvrier européen, París, Edi, 1967; F. L'Huiliier (éd.): L'opinion publique européenné devant la Révolution russe de 1917, París, Ophrys, 1968; Colloque sur l'année 1917, «Revue d’histoire 
Puede decirse que el lustro abierto en 1917 -lustro difícil para Europa- germina en tierra fertilizada por las nuevas formas de la organización empresarial capitalista. Porque, de hecho, permiten éstas de inmediato un rápido desenvolvimiento del asociacionismo patronal, en muy distintas manifestaciones, pero en buena medida como forma de refrenar el movimiento de reivindicación social y política.

Sería ingenuo explicar la evolución autoritaria, que esa defensa patronal conlleva, como simple respuesta a la situación económica. El fenómeno es en verdad más complejo. Se da una convergencia de miras de esos elementos de significación económica con sectores de significación nacionalista y grupos de contenido tradicionalista, en la acepción más amplia de este término.

Los nacionalistas se oponen a la supeditación de la solidaridad de nación respecto a la solidaridad de clase, que se entiende defendida en aquellos sucesos revolucionarios y en el ideario socialista.

Por su parte, la concepción socialcristiana, por un lado, y antiparlamentaria, de otro, facilita el acercamiento del tradicionalismo a la defensa del orden social capitalista y a la de la personalidad nacional, tal como intentan los otros dos sectores citados.

Así, la convergencia de esos tres componentes (defensa del sistema económico, nacionalismo, tradicionalismo), junto a problemas peculiares, contribuye a explicar la configuración teórica $\mathrm{y}$ práctica de los totalitarismos conservadores típicos del $\mathrm{Pe}$ ríodo Intermedio.

Es el estilo dictatorial que impone Mussolini en Italia (octubre de 1922), Primo de Rivera en España (1923), Gomes da Costa en Portugal y Pilsudsky en Polonia (1926), Venizelos en Grecia (1928), Alejandro I en Yugoslavia (1929).

La imposición se generaliza con el acentuamiento de los trastornos sociales por la crisis del 29: Gömbös en Hungría (1931), Hitler en Alemania, Dollfus en Austria y Carlos II en Rumania

moderne et contemporaine», XV, núm. 1 (1968); Colloque sur l'Europe en novembre 1918, ibidem, XVI, núm. 1.(1969); F. L. Carsten: Revolution in Central Europe 1918-1919, Londres, Temple Smith, 1972.

Para la amplísima bibliografía nacional y regional sobre el tema, he de remitir a mi estudio, en preparación, acerca de Los movimientos revolucionarios europeos de 1917-1921. 
(1933), Boris III en Bulgaria (1934, tras las discontinuas prácticas autoritarias comenzadas en 1919).

El híbrido populismo hispanoamericano de posguerra, el Estado Novo de Getulio Vargas en Brasil (1937) y el Régimen de Franco en España (a partir del mismo año) son los mejores exponentes epigónicos del estilo en cuestión (que, ciertamente, no ha de ser confundido con el fascismo - una de sus más claras expresiones, sin duda-, sino que ha de ser entendido como respuesta a aquella convergencia de los tres esenciales factores citados antes).

La mayor parte de estos sistemas de gobierno coincide en formas afines de poder (dictadura personal, anulación de la división de poderes, supresión o esterilización del parlamento, partido único).

Pero tienen alcance y pretensiones diferentes. No en vano ha distinguido entre ellos Burdeau cesarismos empíricos, dictaduras ideológicas y regímenes totalitarios estrictos.

$Y$, de la misma forma, distintos son sus enfoques del problema social. Si el sindicalismo vertical pasa por ser la modalidad típica de los fascismos y de los regímenes paralelos, lo cierto es que algunas de las dictaduras citadas ofrecen variantes de notorio interés. A la cabeza de ellas está, precisamente, la de Primo de Rivera en España ${ }^{3}$.

La Dictadura peninsular ensaya, en efecto, una fórmula superadora del sindicato único fascista y del pluralismo de los Estados individualistas. Y ello basta para justificar el estudio que empiezan estas páginas: para calibrar lo que hay o no de originalidad y lo que a la hora de la verdad resulta de tal intento.

3 Remito a dos sugerentes síntesis acerca de los regímenes y tendencias autoritarios del periodo entre guerras: E. Nolte: El fascismo en su época, Madrid, Península, 1967, y F. L. Carsten: The Rise of Fascism, Berkeley/Los Angeles, University of California Press, 1969, 256 págs.

Aparte de la amplísima bibliografía sobre el fascismo italiano y sobre el nazismo, son pocos los estudios realizados acerca de los autoritarismos orientales y meridionales. Acerca de aquéllos, vid. Peter Sugar, editor: Native Fascism in the Successor States, 1918-45, Santa Bárbara, ABCClío, 1971, 166 págs., referidas a tal cuestión en los Estados participantes en la descomposición del Imperio Austrohúngaro:

Entre las dictaduras meridionales, figura entre las más olvidadas la española. Como revisión más reciente, vid: la de Shlomo Ben-Ami: The Dictatorship of Primo de Rivera: A Political Reassessment, "Journal of Contemporary History», XII, núm. 1 (1977), 65-84. 
Trataremos aquí, por tanto, de la política social de 1923-1930 en España.

\subsection{LA POLÍTICA OBRERA INTERNACIONAL}

Esta política, sin embargo, implica un comportamiento diverso ante los grupos de reivindicación obrera; diversidad que no se comprende si no se advierte como punto de arranque la existencia de una amplia gama de posturas también diversas entre esos grupos. Y ello, una vez más, en parte como resultado de los movimientos revolucionarios europeos de 1917-1921.

Intentaré sistematizar los distintos comportamientos recordando, por puro afán de facilitar el esquema, su plasmación en otras tantas organizaciones internacionales distintas: II Internacional, Komintern, con los intentos de unión total o parcial de ambas (Internacional $2 \mathrm{1} / 2$ ), e Internacionales cristiana, anarquista y trotskista 4 .

\subsubsection{El socialismo reformista}

Es primicia característica la evolución de la II Internacional hacia el reformismo.

Fundada en 1884, subsiste hasta la primera conflagración como mera coordinadora de los partidos socialistas de ámbito nacional. Rehuye así el intento de centralización del poder y de la doctrina que había dado al traste con la I A.I.T.

La Gran Guerra, por otra parte, revitaliza la II Internacional. Por iniciativa de sus adheridos se desenvuelven los más resonantes congresos pacifistas de aquellos años: la Conferencia de Lugano y Copenhague, Londres y Viena, en 1915; el proyecto de Conferencia de Estocolmo en 1917; el Congreso de Berna en el 1919.

La reunión de Berna tiene lugar al tiempo en que los embajadores de los países en guerra celebran por su parte la Conferencia de la Paz en Versalles. Con aquel Congreso, los

4 Hay varias síntesis acerca de las Internacionales obreras. Remito a la de Annie Kriegel: Historia de las Internacionales, Barcelona, Martinez Roca, 1968, y, sobre las sindicales del mismo tipo, a la de Georges Lefranc: Les expériences syndicales internationales. Des origines d nos jours, París, Aubier, 1952. 
socialistas pretenden de forma expresa influir en el contenido de los tratados de paz. $\mathrm{Y}$ en efecto consiguen, como símbolo máximo de su influencia, la creación de la O.I.T. (Oficina Internacional del Trabajo) en la Conferencia de Washington.

Pero tal resultado presenta ya aquel sabor reformista, que en adelante domina el movimiento.

El propio Congreso de Berna y el de Ginebra de 1920 condenan de hecho el régimen bolchevique ruso por antidemocrático y dictatorial ${ }^{5}$.

En esta actitud hay sin duda una motivación doctrinal. Pero hay también una tercera consecuencia de aquellos movimientos revolucionarios de 1917-1921.

En rigor, con la excepción de la misma Rusia, todos esos estallidos han fracasado en el intento de configurar inmediatamente una nueva organización estatal y social de naturaleza socialista. Todas las intentonas revolucionarias de esos años, con aquella excepción, son reprimidas. Y esto conduce al socialismo al paradójico reconocimiento de que ha comprobado su propia fuerza para la lucha, pero también su debilidad para sostener por sí solo el Estado.

En 1928, y en España, lo afirma Van Roosbroeck, dirigente de la II Internacional, de forma taxativa:

Hay que reconocer que la hora en que vivimos es dificil, y el malestar, si se quieren examinar hasta sus orígenes esas dificultades, proviene de ese hecho primordial. El Socialismo es demasiado fuerte para confinarse en una oposición sistemática, renunciando a una participación parcial en los Gobiernos. Pero, al mismo tiempo, no es lo suficientemente

5 A falta de una adectuada y específica síntesis sobre la II Internacional, vid. Georges Haupt: La deuxième Internationale 1889-1914, París/ La Haya, Mouton, 1964, y, del mismo, Le congrès manqué. L'Internationale à la veille de la première guerre mondiale, París, François Maspero, 1965. Se trata de dos importantes colecciones de documentos.

El pacifismo entre la guerra mundial puede situarse en un amplio contexto con la obra de Peter Brock: Twentieth-Century Pacifism, Nueva York, Van Nostrand Reinhold Company, 1970.

Entre los Congresos citados en el texto -en su mayor parte organizados por internacionalistas pero no por la Internacional-, el más representativo es naturalmente el de Berna, revisado por Robert $F$. Wheeler: The Failure of 'Truth and Clarity' at Berne: Kurt Eisner, the Opposition and the Reconstruction of the International, "International Review of Social History», XVIII (1973), 173-201. 
fuerte para gobernar sólo con entera libertad y soberanamente.

He aquí, en resumen, el problema fundamental que se presenta en casi todos los partidos después de la guerra ${ }^{6}$.

En cierta medida, Indalecio Prieto lo da a entender en la misma ocasión para España:

... en estos momentos no constituimos una fuerza capaz de derrocar el régimen de dictadura ni la monarquía ${ }^{7}$.

aunque el empeño colaboracionista de Prieto no llegará nunca a preconizar el acercamiento a estas dos formas de gobierno.

El de otros socialistas españoles, sí. Y ello es precisamente lo que termina de sellar la originalidad de la política social del período 1923-1930.

Así, estudiar la gestión social de la Dictadura de Primo de Rivera es tanto como hablar de la actitud y la acción del P.S.O.E. y la U.G.T. respecto al nuevo régimen.

\subsubsection{Comunismo e intentos de unificación socialista}

$\mathrm{Ni}$ qué decir tiene que, como en el resto de Europa, el fracaso inmediato de las revoluciones de 1917-1921 no elimina del todo, tampoco en la península, un resto de activismo revolucionario, que insiste en el recurso a la violencia como forma de llegar al poder.

Se articula en grupos diversos: no siempre en partidos comunistas. (Bastará recordar la Liga Espartaquista alemana.) Pero, en la práctica, todos van a ir engrosando aquéllos.

Los partidos comunistas son fundados desde 1918; primero, en Letonia y Finlandia. Durante el lustro siguiente, proliferan por toda Europa (incluida España). Y se articulan en su propia Internacional: la III (o Komintern), fundada en Moscú en 1919.

La III Internacional propugna como fin la coordinación de los esfuerzos para la inmediata realización de la revolución general socialista. Elimina por tanto cualquier veleidad de re-

6. Apud XII Congreso del Partido Socialista Obrero Español. 28 de junio al 4 de julio de 1928, Madrid, Gráfica Socialista, 1929, pág. 215. Van Roosbroeck actúa en este Congreso como delegado de la II Interna. cional.

7 Ibidem, pág. 189. 
formismo. E impone a ese fin, en 1920, Veintiún Condiciones que han de cumplir cuantos pretendan ingresar en sus filas.

En verdad, en el propio año 19 (de nuevo ante el fracaso revolucionario, sobre todo el del espartaquismo alemán y el comunismo húngaro), parece abrir un camino de evolución moderadora que acaba con su disolución en 1943.

En este lento cambio de actitud se inscriben los años que estudiamos aquí: $1923-1930^{8}$.

Para terminar la presentación de las posturas en principio divergentes de la II y la III Internacionales, hay que hacer referencia a las organizaciones sindicales, internacionales también, que las completan.

Respecto al socialismo reformista, si los partidos políticos de ese carácter se inscriben en la II Internacional, las sindicales tienden a hacerlo en la F.S.I. (Federación Sindical Internacional, asimismo llamada Internacional de Amsterdam). Aunque existe desde 1913, celebra en 1919 su primer congreso, en la propia Amsterdam. Cuenta en 1920 catorce millones de afiliados.

En cuanto al comunismo, si los partidos se agrupan en el Komintern, las sindicales lo hacen en la I.S.R. (Internacional Sindical Roja), creada en 1921.

8 La bibliografía acerca de la III Internacional es amplia en especial. Para conocer la aparecida hasta 1958 y 1966 respectivamente, vid. G. Procacci: L'Internazionale Communista dal I al VII Congresso (1919-1953), "Annali», I (1958), 283-315, y Annie Kriegel: Histoire ouvrière aux XIX et $X X^{e}$ siècles, "Revue historique», CCXXXV (1966), 455-489.

Con posterioridad a este año -1966-, y dentro de los estudios globales, destaca la colección de trabajos editada por Aldo Agosti: Problemi di Storia dell'Internazionale Communista (1919-1939), Turín, Fondazioni Luigi Einaudi, 1974.

Acerca de los primeros" años de la organización, también después de 1966 ha sido publicada la importante obra de Branko Lazitch y Milorad Drachkovitch: Lenin and the Comintern, vol. 1, Stanford, Hoover Institution Press, 1972, donde se reelabora la vieja visión del propio Lazitch: Lénine et la $I I I^{*}$ Internationale, París, 1950.

Sobre la fundación de los partidos comunistas, hay otro compendio de Lazitch: Los partidos comunistas de Europa, 1919-1955, Madrid, Instituto de Estudios Políticos, 1961, y un reciente ensayo de Neil McInnes: The Labour Movement Socialists, Communists, Trade Unions, en Arnold J. Toynbee (ed.): «The Impact of the Russian Revolution 1917-1967. The Influence of Bolshevism on the World outside Russia», Londres, Oxford University Press, 1967, págs. 32-133. 
$Y$ hay desde luego intentos de unificación entre ambos sectores, en la medida, sobre todo, en que la III Internacional abandona su inicial postura maximalista.

Con esa intención - la de fundir II y III Internacionalesnace en 1921 la Comunidad Internacional de Partidos Socialistas, también denominada Unión de Viena o, irónicamente, Internacional 2 1/2. Fracasa en su pretensión y acaba por fundirse con la II en 1923.

Son más fructíferos los tratos para unir F.S.I. e I.S.R. Aunque no llegan a lograrlo, sí consiguen acordar los modos de acción en sectores y zonas concretas. De esta manera, ambas Internacionales sindicalistas suscriben en 1923 un tratado para los sindicatos europeos de transporte. Y en 1925 crean un Comité Mixto sindical anglorruso.

\subsubsection{Trotskismo, anarquismo e Internacional cristiana}

Es bien sabido que la progresiva moderación del Komintern a que aquí aludimos se incluye en el proceso, mucho más amplio, de la consolidación del régimen soviético. $\mathrm{Y}$ es sabido también que, incluso antes de la muerte de Lenin en 1924, la cuestión del futuro del régimen soviético es uno de los principales motivos del enfrentamiento entre Stalin y Trotsky.

Si éste propugna la prioridad de la revolución general cara al exterior y de la socialización en el interior ${ }^{9}$, Stalin insiste en la más urgente necesidad de la consolidación de Rusia, tanto económica como política.

El enfrentamiento conduce a las luchas políticas que abocan a la expulsión de Trotsky, exiliado en 1929.

Pero, en el exterior, el trotskismo suscita sus propias agrupaciones. $Y$ ellas son las que dan contenido a la llamada Internacional troskista (también denominada IV Internacional), que nace ya en $1938^{10}$.

9 La historia de las actitudes de Trotsky (incluido el lema «Revolución permanente») ha de ser revisada a partir del estudio de Richard B. Day: Leon Trotsky and the Politics of Economic Isolation, Nueva York, Cambridge University Press, 1973.

${ }_{10} \mathrm{La}$ mejor orientación bibliográfica es la de Michel Dreyfus: Sur l'histoire du mouvement trotskyste en Europe de 1930 à 1952, "Mouvement social», núm. 96 (1976), 111-124. 
Para entonces ha surgido, a su izquierda, la Internacional anarquista.

Surge del Congreso celebrado en Berlín en diciembre de 1922 y enero de 1923. Y en ella van introduciéndose los grupos anarcosindicalistas, algunos de los cuales acaban de rechazar la adscripción a la Komintern. (Tal es el caso de la C.N.T. española.)

Por último, existe desde 1922 la Confederación Internacional de Sindicatos Cristianos, que cuenta, en el mismo año fundacional, tres millones de miembros ${ }^{11}$.

Todas estas posturas se hallan también representadas en la vida española. Su estudio entre 1923 y 1930 forma, pues, parte de cualquier investigación acerca de la política social de la Dictadura de Primo de Rivera, como reflejo al menos, y aun cuando este trabajo haya elegido como punto de mira básico el P.S.O.E. y la U.G.T.

\section{Los motivos de la Dictadura española}

El esquema europeo que acabo de trazar exige de entrada matices importantes si se pretende aplicar al caso de España.

Por de pronto, la escasez de estudios acerca de la Dictadura española impide en justicia expresar un criterio preciso y definitivo sobre los motivos que indujeron al golpe de estado del 13 de septiembre de 1923. La motivación fue evidentemente compleja.

El propio Primo de Rivera lo hace saber en el manifiesto que da a luz el mismo día del pronunciamiento. En él se dice justificado por un cúmulo de sucesos en los que se reiteran en particular las cuestiones sociales, los desajustes financieros y las irregularidades políticas, en especial las derivadas de la guerra en Marruecos:

11 Vid. la síntesis dirigida por S. H. Scholl: Historia del movimiento obrero cristiano, Barcelona, 1964. 
Asesinatos de prelados, ex gobernadores, agentes de autoridad, patronos, capataces y obreros; audaces e impunes atracos, depreciación de la moneda, francachela de millones de gastos reservados, sospechosa política arancelaria por la tendencia, y más porque quien la maneja hace alarde de descocada inmoralidad ${ }^{12}$, rastreras intrigas políticas tomando por pretexto la tragedia de Marruecos, incertidumbre ante este gravísimo problema nacional, indisciplina social, que hace el trabajo ineficaz y nulo, precaria y ruinosa la producción agrícola e industrial; impune propaganda comunista, impiedad e incultura, justicia influida por la política, descarada propaganda separatista, pasiones tendenciosas alrededor del problema de las responsabilidades... ${ }^{13}$.

\section{¿A qué realidad responde esta enumeración?}

\subsection{LA MOTIVAC̣ón POLf́tica}

Dentro de este conjunto, la primera peculiaridad del caso español respecto a aquel esquema occidental trazado al comienzo es la prioridad que las propias fuentes asignan al factor político.

Desde ese mismo manifiesto inicial del 13 de septiembre de 1923, la Dictadura se presenta ante todo como clausura de lo que en adelante se denominará la «vieja política»; esto es: el parlamentarismo y los partidos.

Ambas instituciones aparecen como incapaces y aun causantes de los problemas que hasta entonces padece la monarquía constitucional de Alfonso XIII, de cuya inestabilidad es muestra la cifra de 32 gobiernos que la presiden en los veintitrés primeros años del siglo. Y cuya crisis viene manifestándose desde 1917 ciertamente en la radicalización de un cúmulo de problemas políticos de primer rango:

12 Se refiere al ministro de Estado del Gobierno existente, Santiago Alba. Sobre su enfrentamiento al dictador, vid. Maximiano García Venero: Santiago Alba, monárquico de razón, Madrid, Aguilar, 1963, 487 páginas.

13 Manifiesto de Primo de Rivera, 13-IX-1923. Ha sido publicado reiteradamente. Puede verse por ejemplo en Dos años de Directorio. Manifiestos, disposiciones oficiales, cartas, discursos, órdenes generales al Ejército, etc., Recopilados con autorización del Excmo. señor D. Miguel Primo de Rivera y Orbaneja marqués de Estella, Madrid, Renacimiento [1926?], pág. 2 ss. 
En ese cúmulo coinciden los intentos de subversión del orden establecido a partir — se ha afirmado- de elementos mesocráticos, burgueses y obreros, respectiva aunque grosso modo encarnados en las Juntas Militares, la Asamblea de Parlamentarios y la huelga revolucionaria de agosto.

De este modo, se da en ese año la mejor expresión del fenómeno de la ampliación progresiva de las fuerzas disidentes, enfrentadas al régimen a izquierda y a derecha; hasta el límite de poner en precario el consenso preciso para la subsistencia del sistema.

Y la crispación se prolonga, latente al menos, en el lustro inmediato:

Prosigue la atomización de los partidos del turno histórico, abiertamente iniciada en 1913: la escisión del antiguo Partido Liberal Conservador, entre mauristas y conservadores estrictos (éstos, los «idóneos» de Dato), y la ruptura del Partido Liberal Fusionista, entre los seguidores de Romanones y los de García Prieto.

«Si las diferencias entre conservadores y liberales ya resultaban difíciles de establecer desde finales de siglo, las que separan a las distintas fracciones de ambos partidos serán doctrinalmente indiscernibles."

$\mathrm{Ni}$ unos ni otros son capaces de la formulación de un nuevo programa que implique una alternativa aceptable para la problemática de ese momento histórico ${ }^{14}$.

Así, la inquietud mesocrática se exterioriza aún en la difusión del fenómeno de las Juntas de Defensa, que gana al cuerpo de funcionarios de Correos y Telégrafos. El Ministerio (entonces de concentración, en torno a García Prieto) transige ante ellos en marzo de 1918.

En el otoño de ese mismo año, el segundo frente -el catalanismo parlamentario de la Lliga - reabre fuego con el planteamiento de la reivindicación del Estatuto autonómico. $\mathrm{Y}$ su mera formulación basta para arrumbar dos Gabinetes (el de García Prieto y el sucesor, de Romanones).

Por su parte, las Juntas militares reaparecen en 1919, y en el 20 pasan a aglutinar también a los funcionarios de Hacienda.

La carrera de crisis ministeriales totales en el último lustro del régimen constitucional (tres en 1917, tres en 1918, tres

14 Miguel Artola: Partidos y programas politicos (1808-1936), tomo I, Madrid, Aguilar, 1974, pág. 360. 
en 1919, una en 1920, dos en 1921, dos en 1922) prueba a las claras la inviabilidad de una situación, que da lugar al golpe de estado, entre otras razones, porque no se sabe renovar a sí misma.

Pero hay una particularidad importante:

Si el golpe de estado de 1923 se presenta, según veíamos, con afanes de anulador de esa vieja política, la oposición antimonárquica lo recibe en realidad como lo contrario. La anulación del parlamentarismo, para ella, no hace sino esconder una mera defensa del régimen caduco en sus raíces más hondas.

Así lo denuncian los socialistas en el documento conjunto publicado el mismo 13 de septiembre de 1923 por el Partido Socialista y la U.G.T. ante el pronunciamiento militar:

E1 movimiento es en realidad - afirman- una defensa del sistema vigente. EI nuevo Gobierno de coalición liberal-reformista de García Prieto, que estaba en el poder desde el 7 de diciembre de 1922, había nacido con el expreso propósito de renovar el sistema mediante la reforma de la Constitución de 1876, a fin de dar cabida a la libertad de cultos, una ley nueva electoral, la democratización de la composición del Senado y la obligatoriedad de reunir las Cortes durante cuatro meses al año como mínimo. $\mathrm{Y}$ había pretendido además sacar adelante la cuestión de las responsabilidades derivadas del desastre ocurrido en Annual en 1921, cuando una maniobra militar decidida por el comandante general de Melilla, Fernández Silvestre, sin autorización del Ministerio, pero con la probable aquiescencia del alto comisario de Marruecos, general Berenguer, llevó a la muerte al propio Fernández Silvestre con todo su Estado Mayor y motivó un considerable retroceso territorial.

Entre 1921 y 1923, la cuestión de las responsabilidades por este suceso había ido tomando vuelos políticos hasta ser aprobado por el Senado en el 23 el suplicatorio correspondiente para procesar a Berenguer. $Y$ parecía abrirse camino la posibilidad de que la revisión llegara a afectar al propio Alfonso XIII.

Según aquel manifiesto socialista del 13 de septiembre de este último año, "precisamente las vacilaciones advertidas en el Gobierno [García Prieto] y las conductas contradictorias revela[ro]n bien pronto que carecía de fortaleza para resistir las presiones contrarias» a ese propósito de revisión. $\mathrm{Y}$, en efecto, justamente «esas presiones, hasta ahora actuantes en la 
sombra, son las que han salido descaradamente a la luz de la calle» con el golpe de estado de Primo de Rivera.

En consecuencia, el pronunciamiento de éste "pretende intensificar una acción guerrera [la de Marruecos] que en catorce años de desarrollo sólo ha cosechado enormes desaciertos».

$Y$ en ello yace la paradoja apuntada: «Lo que España repudia es lo que, por lo visto, precisamente quieren imponer los generales sediciosos» ${ }^{15}$.

La acusación de contradicción entre sus intenciones profundas (la defensa del orden establecido) y sus afirmaciones (enfrentamiento al régimen de partidos y parlamento) reaparece una y otra vez en la literatura política bajo la misma Dictadura. Entre los propios líderes socialistas opuestos a colaborar con ella, Teodomiro Menéndez afirma en 1928:

«El Directorio no vino a extirpar viejos políticos.» Al contrario: en 1923,

llegó el momento en que, por la acción del Partido Socialista y de la minoría parlamentaria, esa situación [la del viejo régimen] empezaba a cambiar. La campaña de Barcelona, la destitución de Martínez Anido y Arlegui, el nombramiento de la Comisión de los veintiuno, la forma en que iban a depurar las responsabilidades y a estudiar y debatir el expediente Picasso, eran una prueba de que la política española en el Parlamento empezaba a cambiar seriamente, precisamente por la presión del Partido Socialista y de la clase trabajadora.

No se venía, pues, a expulsar viejos partidos políticos; se venía a evitar las responsabilidades de Marruecos, y las responsabilidades de Marruecos es todo el problema español ${ }^{16}$.

15 Manifiesto conjunto del P.S.O.E. y de la U.G.T., 13-1X-1923. También ha sido reproducido con frecuencia. Puede consultarse en Andrés Saborit: Julián Besteiro, Buenos Aires, Ed. Losada, 1967, pág. 164 s., o en Unión General de Trabajadores. Memoria y orden del día del XVI Congreso ordinario que se celebrará en Madrid los dias 10 y siguientes de septiembre de 1928, Madrid, Gráfica Socialista, 1928, $91+11$ págs.

16 Apud XII Congreso del Partido..., 74. Insiste en ella Indalecio Prieto más adelante (ibidem, pág. 133), aduciendo textos de la prensa monárquica coetánea que afirman cómo en efecto el ejército y la corona iban hacia el derrumbamiento por la cuestión de las responsabilidades. Por lo demás, detallaremos después alguno de los aspectos a que alude Teo- 


\subsection{EL PISTOLERISMO}

Aunque esta motivación política es la que se dice primaria, es también cierto que el problema social surge en seguida como otra de las razones importantes del golpe de estado de 1923. En realidad, desde 1919 al menos, los caracteres alarmantes que adquiere esa cuestión en España llevan a sopesar de modo expreso la necesidad de optar entre la imposición revolucionaria o la dictadura ${ }^{17}$.

Según el manifiesto inaugural de Primo de Rivera, la subversión se habría manifestado en una triple vertiente: propaganda comunista, conflictividad laboral y atentados.

Pero, en rigor, sobre el primer aspecto (la propaganda) los testimonios son contradictorios ${ }^{18}$. Y, entre 1921 y 1923, los conflictos se caracterizan por una peculiar recesión del número y la importancia de las huelgas; recesión atribuida a la recuperación económica de los años veinte y a las divisiones de la U.G.T. y de la C.N.T., cuya más aparente expresión fue el nacimiento del Partido Comunista de España en 1920-1921 ${ }^{19}$.

En cambio, es claro y conocido el sorprendente desarrollo de los denominados «atentados sociales»:

En cuanto al número, según la fuente más reiterada (Farré Morego), los atentados sociales pasan de ochenta en 1917 a ciento cincuenta y siete en 1918, trescientos veintiséis en el 19, setecientos cincuenta y siete en el 20 y cuatrocientos treinta $y$ seis en el 21 .

domiro Menéndez en su discurso. Con todo, pueden hallarse los datos necesarios para comprender a qué se refiere en esa enumeración de hechos («la campaña de Barcelona, etcétera») en Melchor Fernández Almagro: Historia del reinado de don Alfonso XIII, 2.. ed., Barcelona, Montaner y Simón, 1934, 611 págs.; duque de Maura y Melchor Fenández Almagro: Por qué cayó Alfonso XIII. Evolución y disolución de los partidos históricos durante su reinado, 2." ed., Madrid, Ed. Ambos Mundos, 1948, 546 págs.

17 Vid. sobre ello los Documents on British Foreign Policy, 1919-1939. Edited by E. L. Woodward. First Series, vol. V: 1919, London, Her Majesty's Stationery Office, 1954, LVII + 1.065 págs.

18 Vid. nota 68 del II.

19 Vid. en este sentido Artola: op. cit. 
Son totalmente diferentes las cifras que da unos años después José Pemartín. $\mathrm{Y}$ aún hay una tercera versión en las del "prestigioso escritor barcelonés señor Marsillach» de que habla Comín.

He aquí conjuntamente las tres series en cuestión: las de Farré -1-, Pemartín -2-y Marsillach -3-:

\begin{tabular}{|c|c|c|c|}
\hline$A \tilde{n} o$ & 1 & 2 & 3 \\
\hline 1917 & 80 & & 28 \\
\hline 1918 & 157 & & 72 \\
\hline 1919 & 326 & 101 & 52 \\
\hline 1920 & 757 & 101 & 201 \\
\hline 1921 & 436 & 132 & 228 \\
\hline 1922 & & 92 & \\
\hline 1923 & & 819 & \\
\hline 1924 & & 18 & \\
\hline 1925 & & 12 & \\
\hline 1926 & & 10 & \\
\hline 1927 & & 4 & \\
\hline 1928 & & 1 & \\
\hline
\end{tabular}

Advierte Pemartín que, de los 819 atentados del año 23, 813 ocurrieron antes del golpe de estado de septiembre ${ }^{20}$.

Es obvio que la disparidad de los datos exige un nuevo estudio del tema. Pero es claro también que las tres series son unánimes en mostrar la gravedad de la cuestión.

Otra cosa es lo que concierne a esa generalización de los atentados.

En su estudio se han distinguido habitualmente tres líneas de fuerza que es conveniente recordar aquí: el pistolerismo al servicio del anarquismo, la vía media del Sindicato Libre y la defensa del orden constituido por parte de los patronos y del Estado.

20 Cf. Farré Morego: Los atentados sociales en España, Madrid, 1922 (reiteradas después por diversos autores); José Pemartín: Los valores historicos de la dictadura española, 2.: ed., Madrid, Publicaciones de la Junta de Propaganda Patriótica y Ciudadana, 1929, pág. 96 s., y Eduardo Comín Colomer: 1922, un año «oscuro», Madrid, s. i. (edición no venal), 1972, pág. 32. 


\subsubsection{Pistolerismo y anarquía}

La generalización del pistolerismo al servicio del anarquismo y del anarcosindicalismo peninsular ha sido insistentemente considerada como una secuela de las formas de comportamiento del espionaje, divulgadas durante la primera guerra mundial. No deja de ser curiosa, por otra parte, la coincidencia cronológica con el desenvolvimiento del gangsterismo estadounidense, que, sobre los precedentes de la mafia decimonónica, se desarrolla en especial desde la promulgación de la «ley seca» en 1919.

El punto de partida del problema español es anterior, no obstante. Según Angel Pestaña, la práctica fue iniciada en 1916 por un grupo anarquista de acción de Barcelona, que ofreció sus servicios a los líderes de la C.N.T., a la que no pertenecían. El primero en utilizarlos habría sido el Sindicato del Arte Fabril y Textil, que lo hizo para presionar a los patronos a fin de obtener diversas concesiones.

Después, el éxito generalizó el recurso, en principio como mero sistema de obtener reivindicaciones concretas. Y la difusión motivó a su vez, de un lado, la conciencia de descontrol de la C.N.T. por parte de sus propios caudillos, en su mayoría contrarios a tales usos. Y dio lugar, de otro, a sendas reacciones -obrera, patronal y oficial-, que hemos de ver por este $\operatorname{orden}^{21}$.

\subsubsection{El Sindicato Libre}

Hay, en efecto, una reacción propiamente obrera, que se enfrenta al pistolerismo en la medida en que éste se sitúa al servicio de una táctica sindical determinada:

En la huelga revolucionaria de 1917, en concreto, dirigentes de la C.N.T. habían observado que el paro fue más fácil y generalizado en los lugares menores, donde existía un solo sindicato, que hacía más asequible la unión; en tanto en los núcleos

21 Cf. Angel Pestaña: Lo que aprendí en la vida, en «Trayectoria sindicalista», Madrid, Tebas, 1974, págs. 172-189, y Alberto Balcells: El sindicalismo en Barcelona (1916-1923), Barcelona, Ed. Nova Terra, 1968, 196 págs. 
mayores era preciso poner de acuerdo un conjunto más o menos complejo de sociedades de oficio.

Consecuente con tal observación, el Congreso de la C.R.T. catalana - sección regional de la C.N.T.- había decidido en 1918 adoptar esa táctica por principio: no solo que en adelante existiera un sindicato único de ramo o industria en las grandes ciudades y un sindicato único de trabajadores en las pequeñas, sino, además, que únicamente a él hubieran de estar adheridos todos sin excepción los obreros de un mismo taller o industria.

Para conseguir esto habría que recurrir a boicotear la admisión o el trabajo de los que no cumplieran tal requisito. $\mathrm{Y}$ parece que de hecho hubo que obligar a algunos, "pistola en mano» ${ }^{22}$, a la sindicación en el correspondiente Unico.

Fue a fin de defender de este principio para lo que en el otoño de 1919 se fundó el Sindicato Libre.

Nació en concreto en una reunión convocada a petición de un grupo de asociados al Ateneo Obrero Legitimista de la barcelonesa calle de Tapinería y celebrada en sus locales el 19 de octubre. Asistían a ella varios trabajadores que en sus intervenciones describieron implícitamente la situación en que se hallaban, forzados a inscribirse y permanecer en una organización con la que no estaban conformes.

Así, Sales -después líder del Libre- «se identificó... como afecto al Sindicato Unico Mercantil» de la C.N.T., pero deseoso de no seguir «contribuyendo a la obra anárquica llevada por la Organización». El metalúrgico Francisco Farré se adhirió a lo dicho por Sales. Y «refirió que los 'Unicos' habían asesinado a varios compañeros suyos, trabajadores de la Casa Girona, al envenenar el agua que bebían en la sección». Vives, otro obrero, de San Andrés, "aclaró que hacía tiempo que trataba de salirse del Unico por ser inhumano y contrario a sus ideales» ${ }^{23}$.

EI local fundacional no era marginal al contenido teórico que alentó al así constituido Sindicato Libre:

2 Marsillach, cit. Comín: op. cit., 33. El testimonio menos discutible sobre el pistolerismo cenetista es el indicado de Pestaña: op. cit., págs. 172189. Sobre la evolución de la C.N.T. a que se alude, vid. Artola: op. cit., .

23 Comín: op. cit., 7 s., sigue a Baratech. Puede verse otro resumen de la obra de éste en el trazado por Antonio Elorza: Cronología del Sindicalismo libre, "Revista de Trabajo», núm. 35-36 (1971), o La utopia anarquista bajo la segunda república española, Madrid, Ed. Ayuso, 1973, 468 págs. 
Sus fundadores fueron - dijo Gafo- «obreros católicos y elementos del Requeté» ${ }^{24}$.

En palabras de Oller Piñol, sus afiliados «pertenecían en su mayor parte a la Comumión Tradicionalista» y a una asociación de camareros y cocineros ${ }^{25}$.

Conforme a Baratech, «Ios Sindicatos Libres surgieron en los círculos tradicionalistas de Barcelona (jaimistas se llamaban entonces), formados por los obreros de dicho núcleo político, el cual contaba por aquella fecha con una veintena de centros obreros, solo en Barcelonas ${ }^{26}$.

Pero, en el mismo acto fundacional del 19 de octubre, Sales subrayó de manera expresa que la organización no debía constituirse como sindicato católico, a fin de evitar la acusación de amarillismo que pesaba sobre los grupos obreros confesionales ${ }^{27}$. $\mathrm{Y}$, en efecto, el Reglamento aprobado en diciembre de 1919 para el nuevo Sindicato Libre sorteó el consiguiente problema con esta fórmula doctrinalmente clara, pero aconfesional:

El pertenecer a esta corporación impone la aceptación y defensa individual y colectiva de las instituciones fundamentales del derecho natural, basada en la concepción espiritualista de la historia de la vida. Así como el respeto a las creencias sobrenaturales de nuestro pueblo.

El planteamiento era igualmente descomprometido al aludir a sus fines:

Pretendía "el mejoramiento moral, intelectual y material de los trabajadores», que, como meta máxima, se realizaría en una sociedad organizada sobre la base de la familia y la «corporación profesional» y regida por «la teoría del justo precio» ${ }^{28}$ : corporativismo y doctrina económica escolástica, que en reali-

24 Cit. Domingo Benavides: El fracaso social del catolicismo español. Arboleya Martínez, 1870-1951, Barcelona, Ed. Nova Terra, 1973, pág. 299.

25 Juan Oller Piñol: Martínez Anido. Su vida y su obra, Madrid, Librería General de Victoriano Suárez, 1943, pág. 34 s.

26 Carta a Maximiano García Venero: Historia de los movimientos sindicalistas españoles (1840-1933), Madrid, Ediciones del Movimiento, 1961, pág. 382 .

27 Siempre en la reunión del 19-X-1919, Sales advirtió "que en Barcelona no podía hablarse de Sindicatos católicos, considerados siempre 'amarillos'» (Comín: op. cit., pág. 8).

28 Cit. Artola: op. cit., I, p. 496 s. 
dad lo entroncaban directamente con los planteamientos socialcristianos.

En este sentido, la orientación aconfesional del Sindicato Libre de Barcelona implicaba un paso adelante en el proceso de emancipación del movimiento obrero cristiano, no sólo respecto a la jerarquía eclesiástica, sino además en cuanto al clero; aunque, en la práctica, la nueva asociación no dejó de tener por ello, de hecho, un claro aunque restringido apoyo clerical, al menos en la persona de los activos sindicalistas Gafo y Maximiliano Arboleya.

En cuanto a su acción concierne, los datos conocidos - sin duda demasiado escasos- permiten suponer que desarrolló alguna actividad de organización propiamente sindical y de presión reivindicativa sobre los patronos. Pero, desde el primer momento, sus fundadores fueron conscientes del choque que había de provocar aquel primer designio defensivo frente a la sindicación única cenetista que absorbería su atención. Y previeron explícitamente que el pistolerismo empleado por grupos de la C.N.T. desde 1916 sería utilizado también contra ellos por ese motivo.

Es por esta previsión por la que uno de los primeros manifiestos del nuevo grupo anuncia "como norma de conducta, si no se nos respeta nuestra libertad, la ley del Talión, pero con ganancia para nosotros en el saldo». $\mathrm{Y}$ concreta dirigiéndose a los obreros:

Aquí se os defenderá contra todo y contra todos, y jay! de aquel que directa o indirectamente ose tocar un cabello de nuestros adheridos. Si el delito, por la cobardía de sus autores, quedara impune, sabremos hacer responsables a sus directores...

Sépanlo sus cabecillas visibles y ocultos; sus vidas responden a las nuestras y de nuestros compañeros de sindicato ${ }^{20}$.

Según Oller Piñol, los libreños (o libres; que de ambas formas serían denominados) advirtieron «que por cada uno de aquellos que cayera le seguirían tres del Unico, y como la advertencia se convirtió en realidad, la respuesta del Libre fue contundente y mayor que el agravio» ${ }^{30}$.

29 Apud Oller Piñol: op. cit., pág. $35 \mathrm{~s}$.

30 Ibidem, pág. $38 \mathrm{~s}$. 
La táctica en cuestión implicaba un problema moral evidente, que tampoco escapó en ningún momento. Según un curioso relato del padre Gafo - pionero del sindicalismo no jerárquico en nuestro país ${ }^{31}$-, que por otra parte repite el planteamiento de Oller,

los directores de la revolución [cenetistas y afines] organizaron las bandas de pistoleros que pretendían ahogar en sangre la naciente sinđicación libre.

$\mathrm{Y}$ antes de contestar con la pistola, los elementos del Sindicato Libre, algunos de comunión diaria, todos católicos a machamartillo, consultaron a sacerdotes si podían usar la pistola. Y también consultaron al cardenal Reig, entonces obispo de Barcelona, si podían organizar el sindicato en la forma que pretendían para oponerse a la tiranía.

—iBendito sea Dios! —dijo el señor obispo-. ¿Y por qué no organizáis el sindicato católico?

-Porque entonces no habría sindicato, señor.

-Bueno, hijos, arreglaos como podáis.

$\mathrm{Y}$ así salieron a la calle, solos, independientes y con la conciencia tranquila ${ }^{32}$.

31 Vid. lo que sobre él indica Juan N. Garcia-Nieto Paris: El sindicalismo cristiano en España. Notas sobre su origen y evolución hasta 1936, Bilbao, Universidad de Deusto, 1960, 290 págs.

32. Apud Benavides: op. cit., pág. 299. En 1927, cuando escribe estas frases, Gafo añade: que "no hace muchos meses se envió una consulta a Roma sobre la doctrina y la táctica del Sindicato Libre.

Y me consta que la contestación ha venido y en ella se dice que el programa del Sindicato Libre puede defenderse, siempre que sean respetuosos con la autoridad" (ibidem).

Con todo, en 1927, tras cuatro años de paz dictatorial, la táctica de los libreños no tenía ya nada que ver con el pistolerismo. Por otra parte, como puede observarse ibidem, pág. 370, el criterio del nuncio Tedeschini en torno al propio año 27 fue expresamente contrario a los libres, no desde luego por el recurso a la violencia, del que quizá no se hizo entonces cuestión (a tenor de los datos conocidos), sino por el afán de defender los sindicatos católicos confesionales. Según Arboleya, ese criterio se habría impuesto por influencia de la Compañía de Jesús, que controlaba el sindicalismo confesional. En el mismo sentido, hay que advertir también que, si el testimonio de Gafo es cierto, en Reig i Casanova hubo de operarse una mutación semejante. Cuando en 1926, siendo ya arzobispo de Toledo, publicó sus Principios y Bases de Reorganización de la Acción Católica Española, señaló el carácter confesional y único que, en su criterio, habían de tener todas las asociaciones afectadas, incluidos Ios sindicatos. (Reproduce esos largos Principios y Bases el "Boletín Oficial Eclesiástico del Obispado de Pamplona», LXVI [1927], passim.) 
En verdad, este planteamiento moral era menos sencillo que lo que ese diálogo parece sugerir. Los propios libres fueron conscientes de que su acción haría pagar a justos por pecadores; puesto que era cuestión sabida el desacuerdo de algunos líderes de la C.N.T. con el pistolerismo ácrata. En el manifiesto de 1 de septiembre de 1920, aquellos lo advierten con claridad:

No nos importa si las Juntas de los sindicatos organizan los asesinatos o no. Sabemos que ellos son, por lo menos, moralmente responsables, y en ellos están, o a su alrededor, los que lo son materialmente ${ }^{33}$.

Defensa o venganza (no es clara su naturaleza), los libres insistieron siempre en justificar su acción en el hecho de que no respondió a un propósito constitutivo de lucha sino a una previsión que en seguida se demostró acertada. Así lo advertía más tarde Ramón Sales:

Mientras en la lucha entablada [por los cenetistas] con patronos hicieron a éstos víctimas de sus pistolas, nosotros nada dijimos. No era función nuestra salir en defensa de la clase patronal. ... Ahora, cuando los cañones de sus star tomaron por blanco los cuerpos indefensos de nuestros queridos compañeros, entonces sí que no tuvimos más remedio que adoptar determinadas medidas para salvar nuestras vidas amenazadas ${ }^{34}$.

Sentado el hecho de su participación activa en la guerra social, la bibliografía, en cambio, ha discutido la atribución de actos concretos a los propios libres: tales como el fallido atentado de 1921 contra Angel Pestaña o la muerte a tiros en 1923 de Salvador Seguí, líderes ambos de la C.N.T.

Pestaña, malherido también a tiros en Manresa el 25 de agosto de 1921, habría sido, según unos, blanco del pistolerismo

33 Cit. Artola: op. cit., pág. 501. Podría afirmarse que, de hecho, una parte importante de los dirigentes de la C.N.T. se manifestó contraria. a los atentados sociales al suscribir el 3-IX-1920 la alianza defensiva con la U.G.T., exclusivamente dirigida a la obtención del restablecimiento de las garantías constitucionales. Tal interpretación del alcance de esta alianza sólo es posible si se admite el juicio del propio Artola (ibidem, I, pág. 500) que la considera "único medio que los sindicalistas tienen para recuperar el control sobre la organización».

34 Apud La Voz, 19-XI-1921, cit. García Venero: op. cit., pág. 381. 
amarillo ${ }^{35}$ o del libre en concreto ${ }^{36}$ : «El atentado contra mí - escribirá más tarde él mismo- fue organizado, pagado e impuesto por el Gobernador de Barcelona, general Martínez Anido, por haberle acusado yo en un mitin celebrado en Zaragoza de ser él el organizador del terrorismo del Sindicato Libre contra los hombres del Sindicato Unico» ${ }^{37}$.

Otras fuentes cercanas al ámbito oficial afirmaban saber que el autor fue un antiguo cenetista impulsado por motivos «de indole económica» ${ }^{38}$. $\mathrm{Y}$ "una opinión exteriorizada en aquel momento" diría que "no se puso bien en claro de qué elementos político-sociales había partido la agresión, pero se suponía, muy fundadamente, que determinados sindicalistas exaltados no veían ya con mucho gusto que su jefe entrase por sendas menos radicales y se dispusiera a llevar el sindicalismo por las vías legales, y meterle en la política general y parlamentarias ${ }^{39}$.

En cuanto atañe a la muerte de Seguí en 10 de marzo de 1923, si la bibliografía más reciente da por supuesta la culpabilidad de los libres ${ }^{40}$ (verosímil, desde luego, dados sus planteamien. tos), los textos de la época no son tampoco tan seguros. Parece que los propios miembros del Sindicato Libre acusaron del hecho a pistoleros de la C.N.T., que habrían actuado movidos por las relaciones que Seguí mantenía con elementos burgueses con ánimo de delatar a los terroristas que había en su organización ${ }^{41}$. De ello sólo es clara la oposición de aquél al pistolerismo ${ }^{42}$.

Pero son más interesantes, por su procedencia, las versiones surgidas en campo socialista. En la Memoria del XII Congreso del P.S.O.E., Saborit - su autor- afirma en 1927 que «no se ha logrado saber quiénes fueron los autores materiales del he-

35 Vid. en tal sentido Antonio Elorza: Prólogo a Pestaña: op. cit., pág. 16.

36 Vid. en este sentido Balcells: op. cit., pág. 169.

37 Pestaña: op. cit., pág. 123.

38 Oller Piñol: op. cit., pág. 146. El mismo autor afirma que únicos y libreños fueron a la huelga - se desprende que en señal de protesta por el atentado-; aunque el dato es confuso (cf. ibidem, pág. 131 ss.).

39 Comín: op. cit., pág. 28.

40 Vid. Elorza: Cronología..., pág. 281, y J. M. Huertas Clavería: Salvador Seguí «El noi del sucre». Materiales para una biografia, Barcelona, Laia, 1976, passim, entre otros lugares.

41 Cf. Oller Piñol: op. cit., pág. 176 ss.

42 Vid. Balcells: op. cit. 
cho» ${ }^{43}$. Pocos años después, Ramos-Oliveira deja sentado que Seguí «había sido asesinado por pistoleros de su propia organización, que se habían pasado, por dinero, al bando de los capitalistas» ${ }^{44}$.

La misma incertidumbre campea en las fuentes sobre otros acontecimientos ${ }^{45}$.

\subsubsection{La defensa patronal}

Decíamos al principio que la defensa contra el pistolerismo surge ante todo de tres frentes: obrero, patronal y oficial. Pues bien, también es en 1919 cuando, en efecto, los patronos toman parte activa en la lucha:

Que se sepa, es en la huelga general de marzo-abril de ese año cuando hace su aparición el primer grupo de pistoleros a su servicio. Se trata de la banda dirigida por el espía alemán titulado barón de König, que contaba con la activa colaboración de Bravo Portillo, antiguo policía y —según versión ácrata, rechazada por un sector de la historiografía - también espía al servicio del Reich.

La banda se disolvió en 1920, según Balcells, por desacuerdo entre capitalistas y activistas, que se dijo llegaron a simular atentado ácratas contra los mismos patronos, con el fin de suscitar nuevas contrataciones ${ }^{46}$.

Mas, para entonces, ya se había desarrollado un buen sustituto: el Sindicato Libre que acabamos de describir, fundado en Barcelona en 1919.

Al presentarlo aquí como sustituto, al menos me refiero a la realidad de que una y otra fuerza se orientaban contra el

43 Partido Socialista Obrero Español. Convocatoria y orden del día para el XII Congreso ordinario del Partido, y memorias reglamentarias de la Comisión Ejecutiva, Subdirección y Administración de "El Socialista", de la minoria parlamentaria y de la Gráfica Socialista, con un breve resumen de la actividad obrera en sus diversos aspectos desde abril de 1921 a diciembre de 1927, Madrid, Gráfica Socialista, 1927, pág. 73.

44 Antonio Ramos-Oliveira: Historia de España, tomo II, México, Cía. General de Ediciones, 1952, pág. 473.

45 Sucede algo semejante con el «atentado» libre contra Indalecio Prieto. Obsérvese la disparidad que existe entre las versiones de Comín (op. cit., pág. 20 ss.) y la que da la memoria citada en la nota 43. Parece tratarse de un incidente circunstancial que no tiene nada que ver, ni en su origen ni en su desarrollo, con los atentados sociales del período.

46 Cf. Balcells: op. cit. 
mismo enemigo - los anarcosindicalistas- aunque lo hicieran por motivos diversos.

Lo que no queda aún claro (y lo que, por lo tanto, la historiografía discute) es si el sindicato requeté, que disparó indudablemente contra los únicos, lo hizo en algún momento no sólo por defender a los obreros, sino también a los empresarios.

Hemos visto que los seguidores de Sales niegan de forma taxativa esta mera posibilidad y se afanan en no ser ni parecer amarillos ${ }^{47}$. Blasonarán incluso en 1922, ante el gobernador civil de la ciudad condal, de haber «sostenido más de quinientas huelgas parciales y boicotajes y dos huelgas generales de ramo" contra los intereses patronales ${ }^{48}$.

Gafo, claro simpatizante, se expresa, en cambio, en un término medio:

Algunos patronos que se veían en peligro... les ayudaron en los primeros pasos, pero nunca hubo en los sindicatos [libres] la menor intromisión patronal. $\mathrm{Y}$ aun aquella ayuda acabó bien pronto ${ }^{49}$.

$\mathrm{Y}$, en tercera postura, un tercer sector de la historiografía afirma sin lugar a dudas su conexión. Según Ramos-Oliveira,

la oligarquía... había hecho del terrorismo un arma política, sirviéndose de los anarquistas contra otros sectores del proletariado y comprando a los pistoleros del Sindicato Unico, los cuales, incorporados a los Sindicatos Libres -organizaciones amarillas inventadas por la reacción-, ponían su experiencia de terroristas, adquirida a las órdenes del Unico, al servicio de las organizaciones patronales ${ }^{50}$.

47 Vid. notas 27 y 34 supra.

48 Manifestaciones de una comisión de sociedades afiliadas al Sindicato Libre, cit. Comín: op. cit., pág. 34 .

49 Apud Benavides: op. cit., pág. 299.

so Ramos-Oliveira: op. cit., II, pág. 472. No parece pueda ponerse en relación esa seguridad de Ramos-Oliveira sobre la incorporación de los pistoleros del Unico al Libre con el llamamiento público que hizo posteriormentes éste, en octubre de 1923, para atraer a los cenetistas a sus filas (cf. Elorza: Cronología..., pág. 283). No cabe ponerlo en relación, primero, porque se había impuesto ya la Dictadura en septiembre y el pistolerismo cesó de inmediato, y segundo, porque la atracción de los territoristas no habría sido realizada seguramente de forma pública como la atracción de los simples obreros sindicados. 
En parecido sentido se expresa Angel Pestaña, en quien acaso se inspira el historiador socialista:

Las pistolas del Sindicato Libre [eran] amparadas, y pagadas en algunos casos, por el Gobierno Civil [de Barcelona], protegidas por la Jefatura de policía y sostenidas y mantenidas espléndidamente por la burguesía catalana.

También él ratifica el trasiego de la C.N.T. al nuevo grupo:

Lo más grave fue ver cómo los trabajadores que habían pertenecido a la Confederación formaron parte de los Sindicatos libres y cómo cotizaban en dichos Sindicatos sabiendo que con sus pesetas, con el dinero que daban, los forajidos que se escondían en aquella organización asesinarían a los "del Unico", sin que por parte de esos trabajadores hubiese un gesto de rebeldía contra aquella situación ${ }^{51}$.

\subsubsection{La defensa oficial: Martínez Anido}

Semejante dificultad, con nuevas implicaciones, presenta lo que atañe a la acción oficial frente al terrorismo.

Según da a entender Balcells, la agitación huelguista europea de 1920 habría contribuido a dar pie al crecimiento del número de atentados sociales desde septiembre en España ${ }^{52}$. Sea cual fuere su motivo, este aumento llevó al seno de las «corporaciones económicas de Barcelona» la idea de reforzar la autoridad. $\mathrm{Y}$, para ello, elevaron entonces un escrito al Gobierno, que presidía Dato, en el que pedían el relevo del gobernador civil Federico Carlos Bas, a quien juzgaban contemporizador. El 8 de noviembre de 1920, Dato respondió con el nombramiento del general Martínez Anido como gobernador civil, con autorización expresa verbal del presidente del Consejo para «obrar con entera libertad; pues el Gobierno no le creará dificultad alguna a sus iniciativas» ${ }^{53}$. El general venía siendo hasta entonces, desde febrero de 1919, gobernador militar en la propia ciudad catalana.

No sabemos hasta qué punto el descenso de atentados sociales en 1921, si son ciertas las cifras de alguno de los cómputos

51 Pestaña: op. cit., págs. 127 s., 190.

52 Cf. Balcells: op. cit., pág. 158.

53 Cit. Oller Piñol: op. cit., pág. 52. 
existentes, está ligado a su gestión ${ }^{54}$. De cualquier forma, y con su implícita aquiescencia, Martínez Anido quedó a partir de entonces convertido en símbolo de la represión violenta contra las violencias cenetistas.

Según el general López de Ochoa, enemigo político del nuevo gobernador civil, «el general Martínez Anido y el jefe de Policía, el general Arlegui, tuvieron, durante el período de su mando, aterrorizada a Barcelona con bandas de asesinos que, preservados por el carnet que les entregaba el Gobierno Civil y la Policía sancionando como buenos todos sus actos, robaban y mataban sin más ley que su capricho y el de sus amos», hasta el punto de que «estos hombres cuentan en su historia más de cuatrocientos asesinatos de obreros e intelectuales catalanes» ${ }^{55}$.

Según otra afirmación frecuente, uno de los instrumentos más caracterizados de Martínez Anido fueron nuevamente los libres, omnipresentes, como ve, en la lucha social catalana. El hecho no deja lugar a dudas desde el momento -años después- en que el propio militar afirmó la relación en términos sorprendentes:

Lo que hice fue que se levantara el espíritu ciudadano..., recomendando a los obreros libres que por cada uno que cayera deberían matar a diez sindicalistas ${ }^{56}$.

Si esos obreros «libres» son los del sindicato de este nombre, como parece, no tiene sentido la afirmación de Oller Piñol, ayudante de Martínez Anido, según la cual éste «no tenía contacto alguno con los obreros del Unico ni con los disidentes; no conocía a ninguno de ellos; pero podemos suponer que le inspiraron simpatía los segundos ${ }^{57}$.

La relación, insisto, parece indudable: fuese por el apoyo que el militar les prestó, según Prieto, concretamente para alquilar los pistoleros y realizar los atentados ${ }^{58}$; fuera con el "amparo» impreciso de que habla Gafo ${ }^{59}$.

54 Vid. nota 20 supra. Me refiero al cómputo más conocido, el de Farré Morego. Los otros dos describen todo lo contrario.

55 S. López de Ochoa: De la Dictadura a la República, Madrid, Ed. Zeus, 1930, pág. $45 \mathrm{~s}$.

56 Discurso de 17-VII-1927, apud Maximiano Garcia Venero: Historia de las Internacionales en España, tomo II, Madrid, Ediciones del Movimiento, 1957, pág. 348.

57 Oller Piñol: op. cit., pág. 34.

58 Ibidem, pág. 145.

59 Apud Benavides: op. cit., pág. 298 s. 
Al menos sabemos que, nombrado gobernador civil Martínez Anido el 8 de noviembre de 1920, el 19 el militar recibía una comisión de los libres, que ofreció en nombre de éstos ponerse «incondicionalmente al lado de su autoridad» ${ }^{\infty}$.

La medida de la colaboración pueden comenzar a darla los relatos de atentados que publica Oller Piñol, en los que cabe entrever un cierto empeño por impedir pero también por encubrir los de los libres y perseguir en cambio los cenetistas ${ }^{61}$.

La gestión del militar cesó a los dos años de iniciada, en octubre de 1922, ante la decisión del Gobierno de Sánchez-Guerra de no seguir permitiendo la libertad de acción y los medios expeditivos empleados por el jefe de policía Arlegui y por Martínez Anido. El propio Oller Piñol deslizaria la sospecha de que la negativa de éste a favorecer a los catalanistas en la política regional indujo a la Lliga a condicionar su gubernamentalismo al cese de los dos militares ${ }^{62}$. El enfrentamiento de los nacionalistas se había exteriorizado en efecto el 1 de agosto del propio año a raíz de una moción de protesta aprobada por la Diputación de Barcelona contra la frecuencia de los atentados sociales, que fue interpretada como crítica a la gestión del general ${ }^{63}$.

\section{Las organizaciones de reivindicación obrera en 1923}

Pese a la densidad de las incógnitas que rodean la mayoría de los hechos expuestos, lo cierto es que la lucha social de 1919-

60 Cf. Oller Piñol: op. cit., pág. 57 s.

61 Vid. ibidem, passim.

62 Cf. ibidem, 119 ss.

63 Cf. Comín: op. cit., pág. 27. La personalidad de Martínez Anido reclama un estudio riguroso. Es curiosa la visión que da de él José Calvo Sotelo: Mis servicios al Estado. Seis años de gestión: Apuntes para la Historia, Madrid, Instituto de Estudios de Administración Local, 1974, pág. $21 \mathrm{~s}$. (Si no lo indico expresamente, haciendo alusión a la fecha de edición -1974-, siempre que cite esta obra de Calvo Sotelo lo haré según la paginación de la primera edición de la misma, aparecida con cierta variante en el título: En defensa propia. Mis servicios al Estado, Madrid, Librería San Martín, 1932, 315 págs.). Interesa así mismo la visión del problema social de estos años que trazan Jesús Pabón (Cambó, tomo II, Barcelona, Ed. Alpha, 1969) y Carlos Seco Serrano: Alfonso XIII y la crisis de la restauración, Esplugas de Llobregat, Ariel, 1969. 
1923 parece hallarse con seguridad en la base del replanteamiento de las fuerzas obreras que se aprecia en los mismos años, como uno de los factores que más influyen en él.

\subsection{EL SOCTALISMO}

La actitud del socialismo en 1923 obedece en su aspecto fundamental a las decisiones del Congreso extraordinario del P.S.O.E. celebrado en diciembre de 1919. En él se cierra teóricamente una década de acción antirrégimen coordinada con la de los partidos republicanos, que había comenzado con la formación de la Conjunción republicanosocialista en 1909.

En esta clausura formal de esa colaboración en 1919 influye probablemente, se ha dicho, el éxito de la revolución rusa de octubre de 1917, el fracaso de la huelga general española del mismo año (acción aún conjuncionista) y la crisis económica de la posguerra ${ }^{64}$.

Pero el mismo Congreso del 19 aleja al propio tiempo al Partido Socialista español de la postura maximalista inversa, al decidir por 14.010 votos contra 12.497 el mantenimiento en la II Internacional. Suponía esto implícitamente, si no condenar, sí renunciar a integrarse en la Internacional comunista.

La decisión provocó la separación consiguiente de algunos partidarios del Komintern. Todavía en 1920, un segundo Congreso extraordinario del Partido Socialista reunido por ello dictaminó a favor de adherirse a la III Internacional, pero condicionándolo a mantener la propia autonomía en la lucha y el derecho a revisar las decisiones de Moscú.

Las « 21 condiciones» para pertenecer a la Internacional comunista, fijadas en el II Congreso de esta entidad aun en el año del 20, impidieron tal libertad, no obstante. $\mathrm{Y}$ ello forzó la reunión de un tercer Congreso extraordinario del partido es-

64 Juan Pablo Fusi: El movimiento socialista en España, 1879-1939, «Actualidad Económica», núm. 845 (1974), 59-81, jugosa revisión del tema a partir de la investigación realizada por el mismo autor sobre la Politica obrera en el País Vasco 1880-1923, Madrid, Ediciones Turner, 1975, 560 págs. Afirma arriba que la decisión del Congreso de 1919 cierra sólo teóricamente la fase de colaboración con los partidos republicanos porque en algunas zonas - Fusi lo observa en Vizcaya en la actividad política de Indalecio Prieto ante todo- esa colaboración continúa siendo un hecho en las contiendas electorales posteriores al 19. 
pañol, en 1921, que decidió, explícita y definitivamente, rechazar la organización moscovita por 8.812 votos contra 2.311 a favor y 193 abstenciones ${ }^{65}$.

Aunque fueran muy pocos los socialistas que pasaron a integrar el consiguiente Partido Comunista, lo cierto es que el clima de desacuerdo existió. Y a esto aún se sumaría, en julio de 1923, la cordial pero formal separación de la Federación Catalana del P.S.O.E. para constitur la Unió Socialista de Catalunya.

Nacía esta Unió «con un sentimiento de absoluta lealtad hacia los principios, doctrina y táctica del Socialismo y, por consiguiente, de lealtad y adhesión hacia los correligionarios de todos los países». Pero intentaba adecuarlos a la conciencia nacional catalana: pretendía en concreto «la manifestación genuinamente catalana de la aspiración común y universal de llegar al establecimiento de una sociedad mejor».

Aún subrayaba su cordial separación del P.S.O.E. al ofrecerse como "colaborador constante de la obra seria, vasta y consistente que realiza, con el aplauso de todos los hombres libres, el Partido Socialista Español» ${ }^{66}$.

Reunida, en consecuencia, ante este anuncio de la constitución de la Unió en 1923, la Comisión Ejecutiva del propio P.S.O.E. contestó agradeciendo la nota, aunque también añadiendo que «no se cree obligada a dar una opinión respecto a la misma, esperando que lo hagan el Comité Nacional y el Congreso, que en el año venidero se ha de reunir» ${ }^{67}$. Este Congreso de 1924 no tuvo lugar. Lo impidió el Directorio de Primo de Rivera, al menos en la práctica.

65 El proceso puede seguirse en Artola: op. cit., 1. Sobre el tercer Congreso extraordinario del P.S.O.E., el de 1921, utilizo las cifras de votantes que se desprenden del Partido Socialista Obrero Español. Convocatoria y orden del dia..., pág. 190 ss. No concuerdan con las de RamosOliveira: op cit. pág. 472, que habla de 8.808 en contra y 6.025 a favor. 66 Nota de la Unió Socialista de Catalunya, apud Partido Socialista Obrero Español. Convocatoria y orden del dí..., pág. 211.

67 Ibidem, pág. 212. Sobre la Unió en el contexto catalán, vid. Isidro Molas (Lliga catalana. Un estudi d'Estasiología, tomo II, Barcelona, Edicions 62, 1972, pág. 277) y sobre todo Josep-Lluís Martín i Ramos: La Unió Socialista de Catalunya (1923-1936), Esplugues de Llobregat, Ariel («Recerques», 4), págs. 155-190. 


\subsection{ANARQUISMO Y SINDICALISMO}

La situación de la Confederación Nacional del Trabajo no era mejor en 1923. En su III Congreso, en diciembre de 1919, se habían esbozado ya la fisura terrorista de Ascaso, Durruti y García Oliver y la comunista de Andrés Nin, y Arlandís; ambas en los propios cuadros dirigentes ${ }^{68}$. Y a esto había de sumarse aún, a partir, sobre todo, de 1920 , la insistencia de signo contrario de algunos líderes, en particular Salvador Seguí, en una línea "posibilista» ${ }^{6}$ que puede interpretarse en cierto modo como un retorno a las fuentes del sindicalismo revolucionario.

Este último matiz, que no siempre ha sido debidamente indicado, requiere una precisión conceptual de base:

Aunque el concepto ha sido objeto de debate, por sindicalismo revolucionario se entiende en su origen no una ideología, sino una táctica, surgida en Francia en los años noventa del siglo XIX ante la división y con ella la ineficacia de los grupos políticos de reivindicación obrera. Esa táctica nueva consiste en convertir el sindicato en grupo de presión para obtener concesiones precisas, laborales en un principio, eventualmente ideológicas pero sin que presupongan por sí solas adscripción de tal táctica a un sistema de ideas determinado.

Las armas principales para ello eran la huelga y la acción directa (que no es, como suele darse a entender a veces, violencia, sino relación directa obrero-patrono: sin intermediarios de ningún tipo ni por tanto tampoco aceptación de la función esencialmente mediadora del Estado) ${ }^{70}$.

68 Vid sobre ello Artola: op. cit., I, pág. 498 ss.; Gerald Brenan: The Spanish Labyrinth. An account of the Social and Political Background of the Civil War, 5." ed., Cambridge, University Press, 1964, 384 págs., y Juan Gómez Casas: Historia del anarcosindicalismo español, Madrid, Ed. Zyx, 1968, pág. 133.

69 Vid. César M. Lorenzo: Les anarchistes et le pouvoir. 1868-1969, Paris, Editions du Seuil, 1969, pág. 56. (Hay traducción castellana.)

70 La confusión entre «acción directa» y violencia puede encontrarse por ejemplo en determinados escritos de José Ortega y Gasset (vid. la cita de La rebelión de las masas que recoge David Thomson: European Civilization in the Twentieth Century, en "The New Cambridge Modern History. Volume XIII. The Era of Violence 1898-1945», Cambridge, University Press, 1964, pág. 559. Hay traducción castellana.)

Angel Pestaña (loc. cit., pág. 367) insiste en la existencia de la equivocidad del término "acción directa». 
El estilo, la oportunidad y la eficacia del sindicalismo revolucionario llevó al inmediato desenvolvimiento de una ideología, la anarcosindicalista, que se adecúa perfectamente a esa táctica, pero que la instrumentaliza para los fines ácratas, teorizándola. Así, acepta por un lado el principio marxista de la lucha de clases para dar un sentido ideológico a la acción sindical y, de otro, desarrolla la idea de Bakunin de concebir el propio sindicato como célula básica para la organización de la futura sociedad sin Estado. Los medios siguen siendo los mismos: huelga y acción directa; con la salvedad de que refuerza la importancia de la huelga general como instrumento revolucionario cara al cambio de régimen.

A partir de los primeros años del siglo xx, anarcosindicalismo y sindicalismo revolucionario tienden a presentarse como sinónimos, aunque nunca haya habido verdadera identificación.

En principio, por ello, el anarcosindicalismo es uno de los sindicalismos revolucionarios posibles. $\mathrm{Y}$, de otro lado, el anarcosindicalismo es también una de las concreciones posibles del anarquismo. Pero tampoco es sinónimo de anarquismo, puesto que éste por sí. solo no impone una táctica determinada ni se ciñe a la acción obrera.

De ahí que tampoco en España pueda mantenerse esa identificación que con tanta frecuencia se sobreentiende entre C.N.T. y anarquismo. Sino que, junto a la Confederación Nacional del Trabajo, subsisten siempre organizaciones ácratas independientes de aquélla por completo, con los mismos $u$ otros medios diversos de acción.

Precisamente es en esta segunda distinción en la que venía a insistir de manera implícita el posibilismo de Salvador Seguí, que hay que comprender por lo tanto como versión hispánica de la coetánea reconversión y decadencia del anarcosindicalismo europeo tras la primera guerra mundial.

Seguí no debió pretender la ruptura (que hubiera resultado difícil y peligrosa) del sindicalismo revolucionario con el anarquismo de la C.N.T. Pero intentó eludir este problema insistiendo en la distinción entre el ideario ácrata (mantenido, pero sólo como ideal) y la necesidad de centrarse en una acción sindical inmediatamente empeñada en la mejora de la situación material del proletariado, que asi haría posible la revitalización del movimiento ${ }^{71}$.

71 Vid. Lorenzo: op. cit., pág. 56. 


\subsection{Los nuevos grupos: el Partido Comunista de España}

Por lo demás, las quiebras del socialismo y de la C.N.T. debieron contribuir a acentuar la sensación de desacuerdo y por tanto debilidad en el movimiento obrero porque además distaron de dar lugar a fuerzas nuevas que las suplieran.

La Unió Socialista de Catalunya no tuvo tiempo de adquirirla, nacida en julio y realizado el golpe de estado en septiembre de 1923.

El Partido Comunista se gestó con dificultades. Los separados del P.S.O.E., tras el Congreso de éste en 1919, que formaron en 1920 el Partido Comunista Español, se unieron en 1921, con reticencias - por desconfianzas personales según parece-, al Partido Comunista Obrero Español constituido por los disidentes del Congreso del propio grupo socialista celebrado en 1921. Ambos formaron entonces el Partido Comunista de España. Pero todavía quedó una minoría discorde, que fundó la Unión de Cultura Proletaria, luego paulatinamente diluida en aquél.

Respeto al Partido Comunista de España, contaba en julio de ese año 1921 cinco federaciones regionales, que se ha dicho eran fuertes, en especial, en Asturias y Vizcaya ${ }^{72}$. Pero investigaciones y fuentes vienen poniéndolo en duda en fechas recientes:

Según las memorias de uno de los fundadores del grupo, José Bullejos, nombrado en 1921 secretario general del Sindicato Minero de Vizcaya, «el nuevo Partido, el Partido Comunista, nació a la vida política como grupo minoritario de poca importancia y sin fuerzas sindicales, situación que conservó hasta el año 1936. Nunca consiguió, ni aun en los años de la guerra civil, convertirse en partido mayoritario. Cuando en 1921 se reunió el primer Congreso del Partido Comunista de España ${ }^{73}$, la cifra

72 Vid., por ejemplo, Artola: op. cit., I, pág. 534.

73 Hay algún error en esta referencia. Las únicas asambleas comunistas celebradas en España en 1921 parecen haber sido, en marzo; el I Congreso del Partido Comunista Español (no del Partido Comunista de España, aún no existente) $y_{\text {; }}$ en noviembre, la conferencia de fusión entre aquel Partido Comunista Español y el Partido Comunista Obrero Español, que dio lugar - ahora sí- al nacimiento del P. C. de E. Sin embargo, el I Congreso del P. C. de E. no fue celebrado hasta marzo de 1922. (Cf. Artola: op. cit., I, pág. 528 ss.) 
de afiliados, calculada a base de los delegados, era de 1200 , cantidad muy superior a la realidad ${ }^{74}$. Como se verá, teniendo en cuenta que 6.094 afiliados habían votado por la Tercera Internacional en el Congreso Socialista, la mayoría optó por continuar en el viejo Partido Socialista, salvo un pequeño grupo que permaneció al margen de ambos partidos durante algún tiempo. Incluso entre los firmantes del Manifiesto escisionista constitutivo del Partido Comunista hubo varios que al final se retractaron ${ }^{75}$.

Las fuerzas políticas y sindicales más importantes del nuevo partido se localizaron en las regiones de Vizcaya y Asturias...

La base sindical era poco extensa. Se limitaba a Vizcaya, Asturias y Madrid. Sólo en Vizcaya el Partido Comunista había conquistado la mayoría de los sindicatos... La fuerza sindical más poderosa e importante la constituía el Sindicato Minero de Vizcaya, de base regional, que agrupaba al 90 por 100 de los obreros mineros ${ }^{76}$.

Pero esta última valoración de Bullejos, única positiva, ha sido rectificada también por la investigación de Juan Pablo Fusi. Según este autor, al Partido Comunista tan sólo se sumaron, prácticamente, "núcleos no muy numerosos de las Juventudes Socialista de Madrid, Asturias y Bilbao». Y, «en la organización que tan a menudo se considera como el 'bastión comunista' de aquellos años, el Sindicato Minero de Vizcaya, los comunistas sólo controlaban la sección de Bilbao; las secciones de Somorrostro estaban divididas y la más fuerte de todas ellas y de todo el Sindicato, la sección de La Arboleda, seguía íntegramente al líder socialista de la provincia, Indalecio Prietos ${ }^{7}$.

Por otra parte, la situación del comunismo español todavía empeoró entre 1921 y 1923, antes de recibir el golpe de gracia

74 Si el dato es cierto, resultaría exagerada la afirmación que recoge ya con reservas Miguel Artola (ibidem) según la cual sólo el P.C.O.E. decía contar en mayo de 1921 con 6.000 afiliados.

75 Parece referirse al tercer Congreso extraordinario del P.S.O.E. -abril de 1921) y a la siguiente declaración escisionista, alguno de cuyos firmantes, en efecto (al menos García Quejido) regresó al Partido Socialista más tarde (cf. ibidem, y Brenan: op. cit.). La cifra de votantes que da Bullejos no tiene nada que ver con la habitualmente aducida.

76 José Bullejos: La Comintern en España. Recuerdos de mi vida, México, Impresiones Modernas, 1972, pág. $26 \mathrm{~s}$.

77 Fusi: El movimiento socialista..., pág. $70 \mathrm{~s}$. Pormenoriza el tema en Politica obrera en el País Vasco, cit. nota 64 supra. 
de la Dictadura. Según Humbert-Droz, presente como delegado de la III Internacional - de la que era secretario-, el II Congreso del Partido Comunista de España, celebrado en julio del 23, mostró al grupo en clara regresión: «Su influencia en la clase obrera española y sobre la política general del país -escribíaha disminuido muy sensiblemente.» $\mathrm{Y}$ ello, por diversas razones: la represión gubernamental, la propaganda reformista y ácrata contra Rusia y el comunismo y, sobre todo, el pistolerismo, que había desplazado el interés por las estrictas reivindicaciones de clase ${ }^{78}$.

\subsection{LOS LIBRES}

Es muy poco clara, por fin, la situación de los sindicatos libres en aquellos momentos.

Ante todo hay que recordar que esa forma de organización del sindicalismo cristiano no queda agotada ni es siquiera iniciada en España por el Sindicato Libre fundado en Barcelona en 1919, del que ya hemos hablado.

En 1912, el canónigo Arboleya creaba un Sindicato Independiente asturiano que, en torno a 1916, había sucumbido como tal cuando, boicoteado por los patronos en términos aún confusos, quedó supeditado al propio control patronal.

Es interesante observar que, a tenor de ciertas observaciones de Arboleya, este hecho podría haber formado parte de una reacción general confesionalista, que aquél atribuía a los jesuitas, por un hipotético deseo de éstos de controlar todo el movimiento obrero católico reduciéndolo al oficial (esto es: al dirigido por el Consejo Nacional de las Corporaciones CatólicoObreras) ${ }^{79}$.

Es sintomático que también fuera en 1916 cuando presiones semejantes -tampoco precisadas- llevaron al jesuita Gabriel Padau a abandonar la Acción Social Popular, organización que, a imitación del Volksverein alemán, él mismo había creado, en

78 Jules Humbert-Droz: Mémoires de... De Lénine à Stalin. Dix ans au service de l'Internationale communiste, 1921-1931, Neuchatel, La Baconnière, 1971, pág. $186 \mathrm{~s}$.

79 Vid. Benavides: op. cit., pág. 372. 
parte para laborar por la formación de un sindicalismo católico horizontal en Cataluña ${ }^{80}$.

La historia de los sindicatos catolicolibres de Gerard y de los libres de Gafo, nacidos en 1912, no ha sido trazada. En todo caso, en un proceso oscuro que debió ir de 1921 a 1924 al menos, parece que las huestes de ambos fueron sumándose a las del Sindicato Libre de Ramón Sales ${ }^{81}$.

Este último grupo, el gran protagonista del período 19191923 según vimos, debió experimentar un crecimiento rápido. Pero los datos son dispares. Oscilan entre 200.000 afiliados en 1920, según Oller Piñol ${ }^{82} ; 150.000$ en 1922 según las cifras del propio sindicato ${ }^{83}$, y el 30 por 100 de la población obrera de Barcelona a principios del mismo año 1922 de acuerdo con Angel Pestaña, que reconoce entonces una sorprendente potencia a este grupo, aunque la considera circunstancial:

Calculo que un treinta por ciento de los obreros catalanes continúan siendo sindicalistas convencidos ${ }^{84}$.

Los demás forman una enorme masa tambaleante, que se inclina siempre de los que ganan. Hoy están con el Libre. Antes estuvieron con Lerroux... El día de mañana, que se apaguen un poco las pasiones y bajen las aguas de la represión, estarán al lado de nuestros ideales.

... E1 Sindicato Libre está hoy atravesando [sic] por dos corrientes. La primitiva y la que ha nacido con el hecho de haber entrado en él gran masa obrera catalana. Esta masa tiene conciencia de sus intereses y creo que se apoderará del Sindicato Libre y llegará a ser éste -el nombre no hace la cosa-, por un tiempo, el organismo que articulará las aspiraciones obreras de Cataluna. La entrada en masa de los metalúrgicos en el Libre ha deshinchado por completo el poder de sus primitivos $-\mathrm{y}$ actuales, es cierto, pero nominales- dirigentes hasta el punto de que el Libre hoy es un

80 Vid. García-Nieto (op. cit.) y, sobre todo, J. Civera Sormani, Basili de Rubí, Xavier Casasses, Antonio Griera: Acció Social Popular a Catalunya, Barcelona, Editorial Franciscana, pág. 51 ss. Estas páginas fueron redactadas por Xavier Casassès.

a1 Vid. García-Nieto: op. cit.

82 Cf. Oller Piñol: op. cit., pág. 40.

83 Cf. García Venero: Historia de los movimientos...; II, pág. 389.

84 Entiéndase: afines a los planteamientos de la C.N.T. 
nubarrón que está preocupando enormemente a las llamadas clases directoras ${ }^{85}$.

Todo es significativo en este párrafo: la posibilidad de una evolución interior en el sindicato requeté, la alusión al enfrentamiento con los patronos y (acaso, sobre todo) la mentalidad que revela el proletariado catalán, susceptible de ser atraído en esa medida, en pleno siglo $\mathrm{xx}$, por una organización de origen y dirección tradicionalista.

En esta rápida revisión del sindicalismo libre español de 1923 hay que aludir por último a un grupo afín a los principios religiosos y organizativos de los anteriores: la Solidaridad de Obreros Vascos, creada en 1911. Apenas se sabe nada de ella, fuera de haber sido presentada hasta ahora como pujante versión obrera del Partido Nacionalista Vasco y, al tiempo, católica y reacia a la intervención directiva del clero ${ }^{86}$.

\subsection{EL SINDICALISMO CONFESIONAL}

En cuanto a los Sindicatos Católicos dependientes directamente de la jerarquía eclesiástica (a través del Consejo de las Corporaciones Católico-Obreras) siguen un ritmo muy distinto en el ámbito industrial y en el agrario.

En el primero, según los escasísimos datos publicados, se

85 Cit. Comín: op. cit., 12 s., que dice se trata de "palabras de Pestaña a un periodista que le visitó en la Cárcel Modelo barcelonesa (principios de 1922)". No indica fuente. La afirmación del propio Pestaña de que a comienzos de 1922 un treinta por ciento de la población obrera de Barcelona podía pertenecer a los libres ha sido recogida en cambio por Antonio Elorza: Cronología..., pág. 282. Como todo lo que procede de este tipo de fuentes -casi las únicas empleadas hasta ahora para estudiar el tema - ha de ser acogido con reserva y dándoles una confianza aproximativa en el mejor de los casos. Es significativo al respecto que Pestaña valorase al mismo tiempo (principios de 1922) en un treinta por ciento de los obreros catalanes la fuerza del anarcosindicalismo (según el texto de Comín) y en un treinta por ciento de los obreros barceloneses la fuerza de los libres (según Elorza).

86 Vid. García-Nieto: op. cit;; Maximiano García Venero: La «Solidaridad de Obreros Vascos» (1911-1937), «Revista de Trabajo», núm. 4 (1964), 7-28; Fusi: Politica obrera..., passim. 
desarrollan lentamente desde 1897 hasta 1919, en que cuentan $35.000^{87}$ o más de 60.000 afiliados ${ }^{88}$, según las fuentes. A partir de entonces, su amarillismo fáctico (no tanto porque son corporaciones verticales, explícitamente como nueva versión del gremialismo propugnado por los tradicionalistas, sino porque de hecho a veces actúan como fuerza rompehuelgas, según GarcíaNieto), los hace víctimas del pistolerismo antipatronal de los años 1919-1923, si es cierta la afirmación en este sentido del mismo autor ${ }^{89}$.

Es sumamente rápido en cambio el desenvolvimiento del sindicalismo agrario católico. Los 166 sindicatos de 1908, agrupados en doce federaciones, son 4.000 en 1922 agrupados en cincuenta y siete, con setenta y cuatro periódicos y 600.000 familias sindicadas ${ }^{90}$.

Esta última cifra sugiere una cuestión historiográfica de interés, que vuelve a incidir sobre la mentalidad tradicional que se esbozaba en la frase de Angel Pestaña sobre la fuerza de los libres en Cataluña:

Aunque los datos publicados no coinciden, sí son lo bastante aproximados para decir que en 1919 la C.N.T. tenía unos setecientos mil federados ( $\sin$ que se sepan datos de los años 19201923, que son de decadencia para ella) ${ }^{91}$.

87 Cf. Eduardo Aunós: Politica social de la Dictadura y colaboración socialista, "Anales de la Real Academia de Ciencias Morales y Políticas", Enciso. No ha de ser confundido este con otro escrito del propio Eduardo Aunós: La política social de la Dictadura. Discurso leído por el Excmo. Sr. D. ... en el acto de su recepción pública y contestación por el Excmo. Sr. Marqués de Guad-el-Jelú, Académico de Número, el dia 23 de mayo de 1944, Madrid, Real Academia de Ciencias Morales y Políticas, 1944, 144 págs. Las referencias que aquí se hagan a uno u otro trabajo habrán de distinguirse por el artículo determinativo con que comienza el título del segundo.

s Cf. García-Nieto: op. cit.

89 Cf. ibidem.

0 Cf. ibidem. Aunque, dada su trascendencia, la cifra habrá de ser revisada, se halla reiteradamente en fuentes de la época. De momento remito a la revisión del tema que preparo sobre ellas.

91 Las cifras que se han dado son semejantes, aunque no sean iguales. Respecto al III Congreso de la C.N.T., celebrado en Madrid en 1919, Artola habla de 699.369 federados (op. cit., I, p. 498), en tanto Brenan (op. cit.) los redondea en 699.500 . Por otra parte, esos individuos «federados» a la C.N.T. y representados en el Congreso están incluidos entre los «adherentes» representados así mismo en él; adherentes o adheridos que el propio Artola cifra en más de 750.000 (op. cit., I, pág. 498) y Balcells en 714.028 (op. cit., pág. 130). 
Por su parte, en 1922, la U.G.T. cuenta 208.170 afiliados $^{92}$, y una cifra menor los libres.

Puede afirmarse, por lo tanto, que el sindicalismo confesional constituye con la C.N.T. (que también incluye al campesinado en sus cómputos) la fuerza laboral numéricamente mayor. Esto, tomando en consideración el número de familias sindicadas en él; no el de individuos, que serían dos millones y medio según García-Nieto, siempre en $1922{ }^{93}$.

La falta de pujanza acertadamente atribuida al movimiento obrero católico en estos años parece válida, por tanto, sólo para el industrial, no para el campesino. La lenta progresión de aquél y la veloz de éste revelan a las claras un distinto grado de adecuación al medio al que se dirigen.

El olvido en que este movimiento rural ha quedado sumido por la historiografía puede deberse en parte al talante de su actividad. Debió ésta redundar ciertamente en una efectiva mejora - grande o pequeña- del nivel de vida en algunas comarcas agrícolas (es algo a comprobar). Pero lo hizo ajustándose al orden establecido.

En concreto, y a reserva de nuevo de lo que las necesarias investigaciones comprueben, los frutos del sindicalismo confesional agrario debieron ser especialmente ricos en cuanto se refiere al desenvolmiento del cooperativismo y del crédito rural. En el primer aspecto, los sindicatos confesionales campesinos contaban en 1922 con once fábricas de harina, veinte molinos aceiteros, quince bodegas, siete centrales eléctricas y otras cuatro fábricas de ramos diversos. Respecto al crédito, no ha sido precisada su trascendencia en la lucha -para ellos prioritaria desde el siglo XIX - contra la usura. Sí se puede afirmar (y el dato parece importante) que, entre 1900 y 1920, los préstamos de las cajas católicas permitieron la creación de 50.000 nuevos propietarios y el arriendo colectivo de una extensión total de 16.086 hectáreas.

Este mismo éxito convive, sin embargo, con un relativo fra-

92 Las cifras de afiliados a la U.G.T., tomadas de las memorias y actas de sus congresos directa o indirectamente, han sido publicadas muchas veces. Pueden hallarse por ejemplo en Fusi: El movimiento socialista..., pág. 66; también en Diego Sevilla Andrés: Historia politica de España (1800-1967), Madrid, Editora Nacional, 1968, pág. 409.

93 Cf. op. cit. Habrá que comprobar si esta cifra se alcanza considerando sindicados a todos los miembros de las 600.000 familias agrupadas en los sindicatos confesionales según el propio García-Nieto. 
caso. Esa acción de reforma progresiva, ajena a toda idea de violencia, no debió conformar al campesino andaluz (ni tampoco a los propietarios meridionales). De hecho, las estadísticas de 1917 revelan que el sindicalismo católico agrario es un fenómeno de la mitad norte de la península, con la Rioja, Burgos, Valladolid, Palencia y Navarra, por este orden, a la cabeza ${ }^{94}$. Un estudio profesional de sus afiliados revelaría la presencia de jornaleros, pero también la de pequeños propietarios y arrendatarios a largo plazo, de acuerdo con la estructura de la propiedad rural de tales regiones.

94 Cf. ibidem. 



\section{BASES DE LA POLITICA SOCIAL DE LA DICTADURA}

Se ha dicho ya cuanto concierne a la complejidad de los motivos que llevan al golpe de estado del 13 de septiembre de 1923. Ahora es preciso insistir en que, con todas aquellas salvedades y en especial pese a la presencia prioritaria de las cuestiones políticas en tal acción, lo cierto es que convergen en ella (junto a las vagas invocaciones de un sistema de autoridad por parte del tradicionalismo y un impreciso fondo nacionalista) también los intereses de los sectores patronales afectados por la inquietud obrera.

Las relaciones entre estos sectores y el Directorio, su obra ordenancista y la política creadora de formación de un cauce legal de reinvindicaciones son, por lo tanto, los tres puntos a examinar a continuación.

La Dictadura, en efecto, a partir de un esquema ideológico determinado (primer punto), desmonta el dispositivo revolucionario del movimiento obrero (segundo extremo), pero intenta mantener la vitalidad de éste encauzándola (tercera cuestión). Serán las dos primeras las que intentaremos examinar en esta segunda parte.

\section{Bases y principios sociales de la Dictadura}

En la cuestión de los principios rectores de la acción social de la Dictadura no se conocen datos suficientes que inclinen a aceptar un esquema apriorístico de ningún tipo. 


\subsection{EL APOYO DE LA BURGUESÍA}

Del apoyo de la burguesía a la Dictadura, en concreto, prácticamente se conocen sólo los escritos de adhesión de la Confederación Patronal Española y de la Federación Patronal Madrilena, publicados en septiembre y octubre de 1923.

Se trata de dos documentos que responden en alguna medida al clima imperante de nacionalismo económico, expresado en términos tópicos del momento («interés nacional», «trabajo nacional») y desenvuelto en especial, al parecer, a partir de 1914, cuando «las excepcionales circunstancias... dan lugar... al auge de las posiciones y tendencias ideológicas que reivindican y definen tesis nacionalistas en el ámbito del pensamiento económico español» ${ }^{1}$.

El primero de ambos escritos aparece al día siguiente del golpe de estado. La Confederación Patronal publica entonces un manifiesto dirigido A los patronos españoles en donde, sin aludir al problema social, reclama uel concurso de todos los intereses y empresas, industriales, agrícolas y comerciales, para lograr el definitivo triunfo del interés nacional, frente a la inmoralidad administrativa y a las concupiscencias de los gremios y clientelas políticas».

Atiende en principio, por tanto, a la posibilidad de jugar la baza puramente política del nuevo régimen, al que alude de forma expresa ${ }^{2}$.

Los patronos esquivan evidentemente el problema social.

Pero esta elusión, por demás conocida (por la reiteración con que la historiografía ha examinado esa nota de la Confederación Patronal), en realidad oculta la primera batalla sorda del régimen militar.

Aunós dirá más tarde, en efecto, que una de las primeras luchas interiores del Directorio la libró el dictador frente a «las voces de sirena que, aprovechando la euforia del triunfo, le aconsejaban al día siguiente del golpe de Estado lanzar una orden de disolución de todos los Sindicatos obreros» ${ }^{3}$.

1 Santiago Roldán y José Luis García Delgado: La formación de la sociedad capitalista en España, 1914-1920, Madrid, Confederación Espanoola de Cajas de Ahorro, 1973, t. I, pág. 327.

2 Apud Dos años..., pág. $10 \mathrm{~s}$.

3 Aunós: Política social..., pág. 44. 
La afirmación debe tener que ver con las referencias que El Socialista aporta cinco días después del golpe de Estado: Advierte que «no sólo la clase trabajadora organizada, sino muchos otros elementos sociales miraron con recelo las actuaciones de entidades como el llamado Fomento Nacional del Trabajo de Cataluña, y la titulada Confederación Patronal Española». Frente a sus criterios económicos incluso se alzan - dice- sectores patronales. Pero lo que ante todo destaca en las manifestaciones anteriores de tales entidades es su

gran enemiga a lo legislado en materia obrera, un odio reconcentrado hacia organismos como los Institutos de Reformas Sociales y de Previsión Nacional, y un desprecio inmenso hacia cuantos intervinieron en la elaboración de las leyes sociales. En la memoria de todos están las recientes maniobras, primero, contra la aplicación de la modesta mejora llamada retiro obrero, y luego, sus campañas, retiradas y vueltas en el Instituto de Reformas Sociales con ocasión de discutirse el anteproyecto de ley de contrato de trabajo. Esos elementos patronales han demostrado clara y reiteradamente que son enemigos de toda legislación social.

Incluso alude expresamente al esfuerzo «desmedido de determinados elementos patronales... que en su afán de halagar al triunfador musitan al oído de éste orientaciones y caminos que sólo convienen a los intereses particulares de estos inspiradores egoístas».

$\mathrm{Y}$ por eso le advierte al dictador el temor y la amenaza que el socialismo implica:

Ignoramos en absoluto cuáles son los propósitos y orientaciones que en materia obrera tienen los rectores de la nueva situación. En ninguna de las declaraciones que hasta ahora hizo el general Primo de Rivera tocó este aspecto de la vida social. Ello lo interpretamos nosotros como acto de discreción.

Pero es que una actitud en otro sentido, afecta a aquellas sugerencias, constituiría "una tremenda equivocación».

En España existe un estado legal en esa materia... Como advertencia leal hemos de consignar que debe tenerse mucho cuidado en tocar a lo legislado, ya que podría tomarse 
como una provocación por parte de los patronos. $\mathrm{Y}$ a todos nos conviene evitarlo.

España tiene además compromisos adquiridos en tal sentido con la Oficina Internacional del Trabajo. Y «todo incumplimiento de los acuerdos internacionales merecerá el oportuno apercimiento de la Sociedad de Naciones ${ }^{4}$.

Hacia el mismo objetivo apunta la intervención de Largo Caballero en sesión de trabajo del Instituto de Reformas Sociales, todavía en septiembre de 1923, para pedir al presidente de este organismo «que declarara oficialmente el nuevo Poder la actitud que pensaba adoptar en relación con la legislación social» ${ }^{5}$.

Cogidos entre dos fuegos, los nuevos gobernantes tardan aún en manifestarse al respecto. $\mathrm{Y}$, cuando lo hacen, comienzan por acudir a corrientes en boga que les permiten mantenerse en una línea aparentemente aséptica, en defensa ante todo del «interés nacional».

Tal es el contenido de la nota dirigida por el Directorio a los patronos en fecha 1 de octubre.

En ella, y en términos confusos, considera obligación sólo secundaria y relativa del Estado «desarrollar la legislación del trabajo encomendada a órganos bien ponderados de representación y bien acreditados de serenidad y preparación». Pero anuncia, no obstante, su pretensión de realizar una «paternal intervención para que las condiciones y relaciones sociales de capital y trabajo sean efectivas y de completo acuerdo siempre entre patronos y obreros».

Ciertamente, a la hora de detallar las obligaciones de cada uno de los dos grupos, la nota insiste más en los deberes de éstos que en los de aquéllos. Se trata de impedir, dice, "que los unos sean arbitrarios repartidores de jornadas y jornales, que los otros incumplan su obligación de rendimiento o se confabulen para modificaciones o imposiciones, e introduzcan novedades caprichosas en las normas convenidas, o conciten revolucionaria e ilegalmente huelgas o resistencias, a que la dignidad y el deber del poder público habrían de poner inmediato y duro remedio ${ }^{6}$.

4 El Socialista, 18-IX-1923.

5 Ibidem, 29-IX-1923.

6 Reproducida en diversos lugares: Dos años..., pág. 59 ss.; Primo de 
El documento escucha dos respuestas lógicas:

El 3 de octubre del propio año 23, la Federación Patronal Madrileña contesta ofreciéndose "para toda obra eficaz en favor del restablecimiento de la justicia y del respeto del derechos ${ }^{7}$. (Es el segundo escrito patronal que anunciábamos antes.) Y, en cambio, el 4, Largo Caballero protesta en El Socialista de las acusaciones implícitas en la nota del Directorio según las cuales la lucha obrera se estaría dirigiendo como fin inmediato contra la producción ${ }^{8}$.

Por lo demás, los datos que atañen a otras gestiones concretas entre ambos grupos - burguesía y nueva Administraciónson hasta ahora escasos. Mola afirmaría después, por ejemplo, que en fecha imprecisa Primo de Rivera solicitó el apoyo económico de los industriales catalanes, pero que luego no hizo uso de él ${ }^{9}$.

\subsection{Nacionalismo ECONÓMICO Y CONCORDIA SOCIAL}

Si ésta es la situación en lo que concierne a las bases sociales de la Dictadura, faltan también estudios acerca de sus esquemas ideológicos. Pero aquí sí parece se puede hablar con seguridad mayor de una doble inspiración clara: nacionalista y cristiana.

La afirmación de esta última característica hemos de verla confirmada en diversas sugerencias de los textos que emplearemos en adelante.

Rivera: El pensamiento de ... Sus notas, artículos y discursos, Madrid, Imprenta Artística Sáez Hermanos, 1929, pág. 121 ss., entre otros.

7 Apud M. ${ }^{2}$ del Carmen García-Nieto, Javier M. ${ }^{2}$ Donezar y Luis López Puertas: Bases documentales de la España contemporánea. La Dictadura 1923-1930, Madrid, Guadiana de Publicaciones, 1973, pág. 83 s.

8 Ibidem, pág. 79 s., o El Socialista, 4-X-1923.

9 «Primo de Rivera solicitó el apoyo del capital catalán para el golpe de Estado a cambio de determinadas concesiones que luego no otorgó, tal vez por no considerarse obligado a ello desde el momento que no hizo uso de los recursos económicos que le fueron ofrecidos, o bien porque cambió de opinión sobre las ventajas del regionalismo» (Emilio Mola Vidal: Obras completas, Valladolid, Librería Santarén, 1940, pág. 250 s.). Aunque es difícil medir el rigor en el empleo de las formas verbales, parece desprenđerse que fue Primo de Rivera el que solicitó la ayuda, se supone que antes de que le fuera ofrecido, contra lo que podría deducirse de la referencia, por lo demás correcta, de Raymond Carr: España 1808-1939, Esplugues de Llobregat, Ariel, 1969, pág. 546. 
En cuanto a aquélla, Artola ha aseverado que

los principios doctrinales que inspiraron el pronunciamiento de Primo de Rivera se justifican en virtud de una afirmación nacionalista que no concibe ninguna posibilidad de organización social distinta del capitalismo imperante. De aquí la triple condena de los partidos, del regionalismo y de la lucha de clases, y la pretensión de trascender los conflictos de que aquéllos son expresión mediante la unión de todas las fuerzas nacionales en una misma empresa ${ }^{10}$.

En el terreno laboral, estos principios quedan sugeridos desde los días iniciales del régimen.

Pocas horas después del golpe de Estado, el dictador declara a El Imparcial:

Las luchas entre el capital y el trabajo son un fenómeno inevitable de nuestro tiempo y a ellas debemos dedicar una preferentísima atención. Hay que legislar en un sentido de amplia concepción democrática, dando al obrero todos aquellos derechos a que es acreedor, encauzando jurídicamente sus relaciones con las clases patronales, intensificando la protección del Estado para la vejez o los casos de invalidez... En cambio, nosotros exigimos del obrero un mayor rendimiento en la producción, porque entendemos que una de las causas, acaso la mayor, de la degradación económica que padecemos es esa falta de producción ${ }^{11}$.

El 19 de septiembre de 1923, unas nuevas declaraciones de Primo de Rivera, que en estos primeros días abunda en ellas, aluden otra vez al «rendimiento del trabajo, la legislación social humana y democrática, por virtud de la cual se sientan amparados los trabajadores y sus familias», como dos necesidades del país ${ }^{12}$.

Y el 28, en fin, una nota del Directorio, en este caso dirigida a los obreros (al tiempo, pues, en que son publicados aquellos dos escritos para y por los patronos) desarrolla ideas parejas:

Comienza por reconocer a los trabajadores que ellos «son lo más importante de la vida del país y lo que más puede influir en su transformación y engrandecimiento».

\footnotetext{
10 Artola: op. cit., I, pág. 557.

11 Cit. Aunós: Politica social..., pág. 45.

12 Apud Dos años..., pág. 43 ss.
} 
Reconoce también «la falta de autoridad y equidad del poder público» al tratar hasta entonces las cuestiones sociales.

Pero asimismo lamenta «una perversa o errónea dirección y orientación de la masa obrera» y les excita por esto «a desligarse de lazos y organizaciones que, aparentando proporcionarles bienes, en definitiva les van llevando por caminos de ruina».

La nota precisa lo que el régimen tolerará:

Asociaciones obreras, sí, para fines de cultura y protección y mutualismo, y aun de sana política, pero no de resistencia y de pugna con la producción.

$\mathrm{Y}$ anuncia lo que ofrece y lo que reclama:

«Una legislación que defienda al obrero de abusos y codicias, que garantice su vida y su vejez, que favorezca su cultura y aun su razonable descanso y esparcimiento», a cambio de «la producción honrada de estos trabajadores». Porque, como advierte el mismo texto al comienzo, «el principal factor de encarecimiento de la vida, en todos sus aspectos, es la imperfección e insuficiencia de la mano de obra y es la falta de un rendimiento de trabajo proporcionado a la duración de la jornada» ${ }^{13}$.

Artola juzga este documento «declaración explícita de la concepción nacionalista socialmente integradora que a los ojos de Primo de Rivera correspondía realizar a su gobierno. Insistirá, por consiguiente, en el carácter trascendente de servicio a la nación, que las actividades económicas tienen" ${ }^{14}$; lo que plantea el problema de hasta qué extremo el dictador se expresa inconscientemente en términos de valor nacionalista sólo por ser partícipe de un modo de expresión que en determinados medios pudiera emplearse entonces, o hasta qué punto lo utiliza porque conscientemente profesa tales ideas. El talante de realismo un poco ingenuo que respiran sus escritos parece abogar por la primera posibilidad.

13 Apud Dos años..., pág. 54 ss.; Primo de Rivera: op. cit, págs. 119-121.

14 Op. cit., I, pág. 556. 


\section{La pacificación social}

Sobre la situación que hemos resumido anteriormente, polarizada en dos grandes cuestiones (lucha social y grupos de reivindicación obrera), la gestión del Directorio va a realizar una primera labor negativa que presenta así mismo un doble cariz: la anulación de esa guerra social y la de los grupos revolucionarios. Ambos extremos son la primera concreción lógica de ese designio integrador que acabamos de ver.

\subsection{EL FIN DE LA GUERRA SOCIAL}

La acción de pacificación social es sorprendentemente drástrica, y clara continuación por otra parte de la política catalana de Martínez Anido y el propio Primo de Rivera (capitán general de Cataluña en el momento de realizar el golpe de Estado).

El 17 de septiembre de 1923 un real decreto ordena la generalización de la institución del somatén a toda España para «la conservación de la paz públicas ${ }^{15}$; aunque la medida no tendrá éxito al parecer por falta de reigambre fuera del principado y porque la pacificación social la hizo innecesaria en seguida ${ }^{16}$.

Lo sorprendente es la prontitud de esa paz.

El 18, otro real decreto atribuye a los tribunales militares "los delitos contra la seguridad y unidad de la patria y cuanto tienda a disgregarla, restarle fortaleza y rebajar su concepto» ${ }^{17}$.

El 20, un grupo de atracadores intenta, fallidamente, robar en la Caja de Ahorros de Tarrasa. Fueran o no anarquistas, como luego se dijo ${ }^{18}$, el hecho venía a encadenarse en la tradición de delitos sociales del período 1919-1923, en el que los

is Apud Dos años..., pág. 35 ss.

16 Cf. Gabriel Maura Gamazo: Bosquejo histórico de la Dictadura, Madrid, Javier Morata editor, 1930, tomo I, pág. 60; y Manuel Aguirre de Cárcer: Glosa del año 23, Madrid, Gráficas Lar, 1944, pág. 314. De la obra de Maura hay al menos otra edición realizada en el mismo lugar y año por la Tipografía de Archivos, también en dos tomos. Citaré siempre sobre la primera de las dos versiones.

17 Cit. Artola: op. cit., I, pág. 556.

18 Vid. Eduardo Comín Colomer: Historia del anarquismo español, tomo II, 2.: ed., Barcelona, Editorial AHR, 1956, pág. 51. 
grupos de acción anarquista habían derivado, en efecto, hacia el atraco ${ }^{19}$. Tras un juicio sumario, el 22 de septiembre de 1923 dos de los presos por aquel acto son fusilados. "Todavía, con posterioridad a este chispazo, saltaron dos o tres en distintas provincias.» Pero ninguno más hasta $1930^{20}$.

En cuanto a los atentados sociales stricto sensu, el descenso es vertiginoso: de 819 en 1923 a 18 en 1924 y cantidades sucesivamente menores en los años siguientes ${ }^{21}$.

Esa radical disminución sería atribuida a tres razones principales: la legislación represiva, la praxis y el mero prestigio de las nuevas autoridades.

El desenvolvimiento de la legislación represiva (primera razón) se concretó en normas como la prohibición de tenencia de armas (real orden de 12 de diciembre de 1923) o las diversas sobre aspectos de orden público a vigilar con especial cuidado (al menos desde la también real orden de 28 de mayo de 1924) ${ }^{22}$. Es difícil admitir que su mera promulgación motivase cambio tan brusco, mientras no conozcamos su ejercicio real.

En los mismos años del Directorio se insistió en el endurecimiento del régimen policial (segundo factor), que, sobre aquella normativa, contribuiría a explicar la pacificación. El Gobierno respondió publicando las cifras de movimiento penitenciario anual en España entre 1907 y 1927. A reserva de lo que un estudio de estas actividades pueda mostrar (sobre todo por la intervención de los tribunales militares desde aquel decreto citado de 18 de septiembre del 23), los datos no dejan en principio lugar a dudas. Las cifras siguen un descenso curiosamente regu-

19 La filiación directa está expresamente afirmada por Angel Pestaña: op. cit., pág. 182, donde escribe: «La conjunción de esos elementos; el hombre idealista que mataba creyendo servir a las ideas, a la causa, y el amoral y propenso al delito que mataba por dinero, daría otro producto más absurdo todavía: el del atracador. No es que todos los individuos que intervenían en los atentados se hiciesen atracadores, no; esto no puede decirse porque no es verdad; pero sí lo es que del seno de los grupos de acción para los atentados salieron los primeros atracadores. Fue una consecuencia, si no lógica y natural, cierta.s

20 Maura: op. cit., I, pág. 59. Enumera esos atracos, dando por supuesto que fueron de origen ácrata, Comín: op. cit., nota 18.

21 Vid lo dicho en el texto que corresponde a la nota 19 de la primera parte acerca del desacuerdo en las cifras que dan Pemartín, Farré Morego y Marsillach sobre los años anteriores a la Dictadura. De nuevo hay que acoger con reservas por tanto los datos que sobre ésta da el propio Pemartín: op. cit., pág. $96 \mathrm{~s}$.

22 Cf. ibidem, pág. 77 ss. 
lar, lento pero constante, desde 22.805 penados en 1907 a 11.134 - algo más de la mitad- en 1927. En los años de Dictadura, incluso se acelera el descenso ${ }^{23}$.

$\begin{array}{ll}\text { Año } & \text { Presos } \\ 1919 & \\ 1920 & 14.791 \\ 1921 & 15.503 \\ 1922 & 15.529 \\ 1923 & 14.123 \\ 1924 & 15.154 \\ 1925 & 12.306 \\ 1926 & 11.963 \\ 1927 & 11.825 \\ & 11.134\end{array}$

Se ha sugerido, en fin, la mera presencia de Martínez Anido y de Arlegui como motivo. El 24 de septiembre de 1923, Primo de Rivera restableció la subsecretaría de Gobernación «con la finalidad precisa - ha afirmado Tuñón- de poner al frente de ella al general Martínez Anido ${ }^{24}$. Y el 27 nombró director general de Seguridad a Miguel Arlegui, que vimos era jefe de la Policía de Barcelona durante la gobernación civil de aquél ${ }^{25}$.

Según su detractor López de Ochoa, el ex gobernador de Barcelona, por miedo, bajo la Dictadura y «en Madrid, alrededor de él, mantiene una guardia negra de 50 pistoleros escogidos», en tanto en la ciudad condal las bandas de pistoleros paraoficiales «siguen cobrando sus sueldos del Gobierno Civil, de Capitanía general, de la patronal, de la Jefatura de Policías ${ }^{26}$.

23 Cifras oficiales del movimiento penitenciario español, publicadas por «La Nación», 21-VI-1927 (apud La Dictadura de Primo de Rivera juzgada en el extranjero. Opiniones de hombres de Estado, diplomáticos, técnicos, periodistas, etc. Edición costeada por el marqués de la Vega de Anzo. Prólogo de José Antonio Primo de Rivera, Madrid, Imp. Sáez Hermanos, 1931, pág. 206 s.).

24 Manuel Tuñón de Lara: La España del siglo $X X$, reed., París, Librería Española, 1973, pág. 123.

25 Cf. Maximiano García Venero: Historia de las Internacionales en España. II: Desde la primera Guerra Mundial al 18 de julio de 1936, Madrid, Ediciones del Movimiento, 1957, pág. 412; Antonio Elorza: El anarcosindicalismo español bajo la Dictadura (1923-1930). La génesis de la Federación Anarquista Ibérica (I), «Revista de Trabajo», núm. $39-40$ (1972), 124, donde se le titula director general de Orden Público.

26 E. López de Ochoa: op. cit., pág. 49. 
Es curioso que, primero como subsecretario y desde el 3 de diciembre de 1925 como ministro de la Gobernación y vicepresidente del Directorio civil, la gestión de Severiano Martínez Anido durante la Dictadura sobresalió, un tanto cáusticamente, en el ramo de Sanidad ${ }^{27}$.

En verdad, en la pacificación social del otoño de 1923 seguramente se mezclaron factores psicológicos, realmente derivados de la presencia de esos hombres en el poder y de la naturaleza militar del nuevo régimen, y factores surgidos de la crisis que atraviesan entonces las dos grandes sindicales revolucionarias (U.G.T. y C.N.T.), plasmada en la escisión comunista.

\subsection{ANULACIÓN DE LOS GRUPOS REVOLUCIONARIOS}

La postura de los grupos de reivindicación obrera ante el golpe de Estado del 13 de septiembre de 1923 (incluso la de los que se escudan en el silencio) es coherente con su historial y resulta precisa de otra parte para entender y calibrar la acción de la Dictadura ante ellos. Vamos a examinarla, pues, como paso previo al estudio de la anulación de aquellos grupos (anarquistas y comunistas ante todo).

Sobra advertir que esta presentación de los grandes temas sociales del Directorio no pretende seguir un orden cronológico y que, por tanto, van a ser resumidos ahora acontecimientos que suceden al tiempo de la pacificación social que acabamos de ver.

2.2.1. La actitud de los grupos de reivindicación obrera ante el golpe de Estado.

a) La actitud de los socialistas

Hemos visto antes cómo el mismo 13 de septiembre en que el golpe de Estado tiene lugar, el Partido Socialista Obrero Español y la Unión General de Trabajadores firman un manifiesto conjunto que, «en términos reticentes y confusos» según los hombres del nuevo régimen ${ }^{28}$, condena a éste como prolongación

27 Vid. Aunós: La politica social..., passim, entre otros autores.

28 Aunós: Politica social..., pág. 44. 
de la política marroquí, considerada máxima expresión de los desastres de la vieja política. Sobre la actitud a adoptar por los trabajadores, no obstante, el escrito aconseja «aislar esa sedición» (en postura simplemente pasiva por tanto) y esperar nuevas instrucciones de aquellas dos entidades socialistas ${ }^{29}$.

Largo Caballero confesará más tarde que, por este documento, «esperábamos represalias, pero el Directorio que se formó no se dio por enterado» ${ }^{30}$.

Con menos dureza, aún el 13 de septiembre, la Junta Administrativa de la Casa del Pueblo de Madrid reitera el consejo en pro de la inacción, en nota oficial de adhesión al manifiesto de las Comisiones Ejecutivas a que acabo de hacer referencia:

La extremada gravedad de los momentos actuales, su matiz y su orientación, obligan a los trabajadores a mirar los acontecimientos con absoluta tranquilidad. La irreflexión, el estado de apasionamiento que pueda reflejarse por los actos externos del movimiento surgido..., causará trastornos irremediables, y esto debe evitarse a todo trance.

Recomienda por ello «muy encarecidamente a los trabajadores no se dejen arrastrar a movimientos o actuaciones que no lleven la plena autorización de los que deben autorizarlo» (precisamente las Ejecutivas) ${ }^{31}$.

Esta pasividad no supone ningún género de aceptación. Vimos que en ese manifiesto conjunto del P.S.O.E. y la U.G.T. se interpreta el golpe de Estado, de forma explícita, como un probable e inadmisible sesgo defensivo del Ejército fracasado en Marruecos.

La falta de serenidad -insiste también la citada nota oficial de la Junta de la Casa del Pueblo- «nos privará de exigir justicia, la justicia que se merecen los que han conducido al pueblo a la rota de Annual y a la bancarrota más ostensible en todos los órganos de la economía nacionals ${ }^{32}$.

29 Apud Unión General de Trabajadores. Memoria y orden del dia del XVI Congreso...

30 Francisco Largo Caballero: Presente y futuro de la Unión Gentral de Trabajadores de España, Madrid, Javier Morata Pedreño editor, 1925, pág. 89.

31 Apud El Socialista, 14IX-1923.

32 Ibidem. 
Y en esa misma línea, el mismo día 13, se expresa el editorial de El Socialista:

Reconoce y reitera que carece de «datos concretos que nos permitan formular un juicio lo más exacto posible». Pero advierte y subraya "que en el alma popular está encendiéndose una formidable explosión de ira reconcentrada contra cuantos representan elementos directores de la guerra de Marruecos», y «que ya no resulta fácil burlar ni el propósito firme de que se haga justicia contra los culpables de los desastres de Marruecos» (las responsabilidades que, efectivamente, vimos vino a zanjar la Dictadura). Duda de si, en efecto, «responderá este movimiento [de Primo de Rivera] a una ofensiva de la minoría pretoriana más reaccionaria para salir al paso de la acción justiciera del pueblo». Mas de hecho adelanta que «la sedición militarista de Barcelona... tiene un matiz encendidamente reaccionario, que significa francamente la oposición más abierta a los anhelos de la mayoría consciente del pueblo español», deseoso en concreto de aquella aclaración de lo acontecido en Marruecos, sobre todo desde $1921^{33}$.

No es extraño que, el 15 , las autoridades militares no sólo comuniquen al propio El Socialista las instrucciones para cumplir con la previa censura establecida entonces, sino que expresamente prohiban al diario tratar sobre la guerra norteafricana o criticar la nueva situación ${ }^{34}$. Desde esa misma fecha, el periódico aparecerá salpicado de líneas o párrafos en blanco, a veces con frases inacabadas, fruto de otros tantos expurgos ${ }^{35}$.

Parece, de otra parte, que la orden de expectación dada por la U.G.T. y por el Partido el día 13, no llegó a tiempo para impedir que la sección ugetista de Bilbao declarase una huelga general de veinticuatro horas contra el pronunciamiento ${ }^{36}$.

\section{b) El Comité de acción contra la guerra y la dictadura}

Pero, de hecho, iban a ser la C.N.T. y el Partido Comunista de España los que se enfrentasen de forma más radical al golpe de Estado.

\footnotetext{
33 Ibidem, 13-IX-1923.

34 Cf. ibidem, 15-IX-1923 ss.

35 Vid. ibidem el editorial del 15 Estamos en nuestro puesto.

36 Cf. Saborit: op. cit., pág. 166, y Partido Socialista Obrero Español. Convocatoria y orden del día para el XII Congreso..., pág. 89.
} 
El mismo 13 de septiembre en que éste ocurría, una reunión de representantes de la Federación Madrileña de los Sindicatos Unicos, de la Federación de Grupos Anarquistas y del Partido Comunista de España constituyen un «Comité de acción contra la guerra y la dictadura». En declaración del 14, este Comité interpreta también el pronunciamiento como paso para «el reforzamiento de la campaña de Marruecos» y como movimiento antisindical, presuponiendo la pretensión de los militares de suprimir las organizaciones obreras. Por ello precisamente, dice, nace el Comité: para «organizar en común la lucha por la defensa de los derechos respetados incluso en los períodos de más brutal represión» ${ }^{37}$.

Como primera medida, el mismo día 14 de septiembre la C.N.T. declara la huelga general ${ }^{38}$, que fracasa ${ }^{39}$.

En segundo lugar, el propio Comité de acción parece intentar la alianza con los socialistas, cara a un más eficaz enfrentamiento con el régimen militar ${ }^{40}$.

La compaginación de repudio y serenidad que propugnan los socialistas llega a acercarse ciertamente a este rupturismo de comunistas y ácratas, en términos que presagian (en interpretación sólo posible a posteriori, sin duda) la apertura en su seno de una línea impaciente por pasar a la acción de oposición abierta también, con incipientes apelaciones incluso a la gestión de los políticos considerados burgueses.

En un artículo puntero, siempre en El Sociatista, lo plantea con claridad Manuel Cordero el 14:

Se alza, efectivamente, en defensa de las libertades individuales, con el sabor más rancio a socialdemocracia: «El sentimiento liberal y democrático —escribe- está pisoteado por la brutalidad de la fuerza.»

$\mathrm{Y}$ así ha quedado, «sin que por parte alguna asome una solución que dé al país aquella tranquilidad necesaria para el des-

37 Apud Eduardo Comín Colomer: Historia del Partido Comunista de España, tomo I, Madrid, Editora Nacional, 1965, pág. 164.

38 Cfr. José Peirats: Los anarquistas en la crisis politica española, Buenos Aires, Ed. Alfa, 1964, 414 págs.; Abel Paz: Durruti. Le Peuple en armes, Bordeaux, Éditions de la Tête de Feuilles, 1972, pág. 80.

39 No encuentro referencia a esta declaración de huelga en Elorza: El anarcosindicalismo...

40 Vid. El Socialista, 19-IX-1923. 
arrollo de su riqueza y sus ideales»: «¿dónde están los hombres civiles?... ¿Es que no son capaces para oponer resistencia, sana y heroica resistencia, a la violencia que va a hacer retroceder la historia de las libertades públicas? ¿Son o no son herederos de la sangre derramada por la conquista de las libertades?»

Se esboza incluso la amenaza cuando advierte que "no tardará en producirse una sana reacción contra lo ocurrido», que marcará «la hora de derramar la [sangre] con utilidad para los ideales nuevos».

«Ellos [la dictadura y lo que implica] son el pasado que vuelve; nosotros, el futuro que triunfará. Serenidad, sí; indiferencia, nos ${ }^{41}$.

Pero, de hecho, es la pasividad lo que constituye su único efecto inmediato.

Así, el P.S.O.E. y la U.G.T. rechazan la incitación a aquella huelga y a esta nueva alianza con la C.N.T. en dos escritos, ambos del día 15:

Primero, en nota oficiosa de El Socialista, reiteran el criterio de aislamiento y condena del régimen militar: «En esa actitud persistimos.» Pero rechazan de modo explícito los rumores acerca de una iniciativa en sentido contrario: "No es verdad que la Unión General y el Partido Socialista hayan autorizado a nadie para declarar movimientos ni algaradas, que no creemos oportunos.» Piensan seguramente en el paro comenzado en Bilbao: «A las secciones del Partido Socialista y de la Unión General les excitamos a conservar la serenidad y la disciplina, bien seguros de que el país hará a todos la debida justicia.» Repudian expresamente "el frente único que se nos ofrece» con el anarcosindicalismo. Y parecen aludir al «Comité de acción contra la guerra y la dictadura» cuando insisten en que «ninguna Sección debe reconocer ni acatar órdenes de Comités anónimos e irresponsables» ${ }^{42}$.

El mismo día 15, las propias Comisiones Ejecutivas de las dos organizaciones socialistas se reúnen conjuntamente otra vez. $\mathrm{Y}$, ahora en nota oficial -no publicada hasta el 18-, comunican su acuerdo, adoptado "con perfecta unanimidad» ${ }^{43}$, de «reiterar a la clase trabajadora la necesidad de abstenerse de tomar cualquier iniciativa a que pudiera ser invitada por impa-

41 Ibidem, 14IX-1923.

42 Ibidem, 15-IX-1923.

43 Discurso de Indalecio Prieto, apud XII Congreso del Partido..., pág. 136. 
cientes de buena fe o por elementos que aspiren, con apariencias engañosas, a lanzar al proletariado a movimientos estériles que puedan dar motivo a represiones que ansía para su provecho la reacción ${ }^{44}$.

Aún el 15 y el 17 insiste en ello la Junta Administrativa de la madrileña Casa del Pueblo, en sendas notas con órdenes muy precisas para evitar algaradas de cualquier género en sus locales ${ }^{45}$.

Se abre paso, por tanto (importa insistir en que por unanimidad, sin los enfrentamientos posteriores), un criterio eminentemente realista. De momento, la oposición del socialismo a la Dictadura se reduce a expresión verbal.

La explicación de ello se abre sólo paso entre líneas. Pero es elemental. $\mathrm{Y}$ anuncia un criterio fundamental en estos años de Directorio: el socialismo va a mirar por el mero interés del mundo obrero; se independiza ya realmente, por tanto, de implicaciones en la defensa de formas de gobierno más o menos plausibles, pero en todo caso clasistas:

A las gentes del medio burgués -escribe El Socialista el 15 de septiembre de 1923 - que preguntan «ingenuamente» por qué no se hace la huelga general que derroque la sublevación triunfante, habría que preguntarles a su vez si se mostrarían conformes con la implantación del régimen socialista en el caso de que triunfase esa huelga general que tanto anhelan.

El razonamiento es, insistimos, diáfano. Los trabajadores no se van a prestar «nuevamente a ser en las calles carne de cañón, para [que] después, al encontrarse libre de obstáculos la situación, don Alfonso llamase nuevamente a los liberales o a los conservadores al Poder, como si aquí no hubiese ocurrido nada».

Cabría (como en el tiempo de la Conjunción republicanosocialista) una colaboración compensada por la consideración de un cambio de régimen como primer paso efectivo hacia un sistema socialista. Pero el país no tiene «ante sí -al examinar las distintas fracciones de la política burguesa- ni el más ínfimo de los grupos que pueda merecerle la menor confianza».

44 Apud Saborit: op. cit., pág. '166.

45 Vid. El Socialista, 18-IX-1923. 
En definitiva, «los obreros organizados no creen llegado el momento de hacer "su" revolución » ${ }^{46}$.

«No romper, trabajadores madrileños -insiste la Junta de la Casa del Pueblo en su nota del 17-, esta conducta de serenidad. Persistir en ella es la más acertada posición de defensa, en los momentos actuales, de los intereses de la clase obrera, y evitando de este modo también que los trabajadores sirvan de víctima propiciatoria para fines que pudieran forjarse por elementos extraños» ${ }^{47}$. «... todos estamos obligados, en las circunstancias presentes - había dicho en la del 15-, a no hacer el juego a los eternos enemigos de la clase trabajadora y de la organización obreras ${ }^{48}$.

No se trata, naturalmente, de una renuncia a la revolución proletaria: pero ni siquiera a la revolución burguesa, que sigue siendo considerada (en correcta ortodoxia socialista) como requisito para el triunfo de aquélla. Lo que los socialistas han de hacer, por lo tanto, es «aumentar su número y su capacidad y no comprometerla en empresas superiores a ella». Pero «los demás que representan el espíritu que llaman de izquierda» tienen el compromiso de evitar que «las derechas... sean... las que dominen las circunstancias y dirijan los pasos futuros de la vida nacional ${ }^{49}$.

Se entiende en esta línea que, el 18 de septiembre, la propia minoría socialista de las Cortes dirija una carta redactada por Fernando de los Ríos al presidente del Congreso, Melquíades Alvarez, en la que le sugiere «debe tomar alguna iniciativa a defender, frente a conculcadores de toda alcurnia y rango, un nuevo régimen civil de libertades efectivas» ${ }^{50}$.

Melquíades Alvarez responde en términos considerados evasivos, quizás injustamente, con un argumento jurídicamente irrebatible: con la disolución de las Cortes, él ha dejado de ser presidente y no posee atribución especial alguna para realizar tal gestión ${ }^{51}$.

\footnotetext{
46 Ibidem, 15-IX-1923.

47 Ibidem, 18-IX-1923.

48 Ibidem.

49 Francisco Largo Caballero: El presente y el futuro, ibidem, 20IX-1923.

50 Apud Manuel Cordero: Los Socialistas y la Revolución, Madrid, Imprenta Torrent, 1932, pág. 54 s.

51 Cf. ibidem, pág. $55 \mathrm{~s}$.
} 


\subsubsection{La anulación de la C.N.T.}

Respecto a la actitud de la Confederación Nacional del Trabajo acabamos de ver cómo contesta al pronunciamiento con la declaración de huelga general, por lo demás fracasada. Es posible, no obstante, que la beligerancia frente al nuevo régimen no constituyera una actitud unánime en sus filas. El mismo 18 de septiembre de 1923, ante la negativa tácita del socialismo respecto a la posibilidad de aliarse con el «Comité de acción contra la guerra y la dictadura», creado el 13 con anarquistas y comunistas, denuncia éste en nota a los obreros el "criterio estático y divisionista» demostrado por la U.G.T. y el P.S.O.E. en sus dos manifiestos del 13 y del 15, también comentados ${ }^{52}$. Pero, todavía el 18, la C.N.T. formula lo que Elorza ha considerado su «primera declaración oficial» sobre el Directorio ${ }^{53}$.

Lo hace en una nota publicada por Solidaridad Obrera; escrito que en realidad no concreta sus intenciones, pero que al menos sí se aparta de la línea beligerante propugnada por el «Comité de acción»:

Si el golpe de Estado no tiene por misión ir contra los trabajadores, contra las libertades que éstos tienen, contra las mejoras alcanzadas y contra las reivindicaciones económicas y morales que paulatinamente se han obtenido, nuestra actitud será muy otra que si todo esto, que es el producto de muchos años de lucha, se veja, no se respeta o se ataca ${ }^{54}$.

No parece, por lo dicho hasta ahora, que el Directorio pretendiera tal vejación de la legislación laboral en que se concretaban sustancialmente los logros alcanzados. Pero tampoco debió tener la menor intención de dar siquiera a la C.N.T. la posibilidad de probar un hipotético afán pacifista, quizá por el peso que el pistolerismo había supuesto en la opinión formada en torno a la organización.

Aunque los datos son confusos y apenas se conocen las ra-

52 Apud Comin: Historia del Partido Comunista..., pág. 166.

53 El anarcosindicalismo..., pág. 124. La calificación de «primera declaración oficial» no parece suponer sin embargo la negación de la realidad de la declaración de huelga general y de su presencia en el Comité de acción contra la guerra y la dictadura.

54 Cit. ibidem, pág. 124. 
zones de tales actos, el hecho es que el 20 de septiembre de 1923 fueron ya clausurados los Sindicatos Unicos de Manresa por las autoridades.

Nombrados Martínez Anido y Arlegui subsecretario de Gobernación y director general de Orden Público, respectivamente, el 24 y el 27, el 28 la C.N.T. solicitaba de la U.G.T., inútilmente, el acuerdo para formar un frente único proletario a semejanza del concebido en 1920.

Quedaba, pues, aislada en su situación cuando el 29 de septiembre de $1923^{\circ}$ el propio Martínez Anido sentó las bases de su disolución legal.

El medio fue la mera exigencia del cumplimiento de la vigente ley de asociaciones, que exigía la presentación periódica de las cuentas y la notificación de los nombramientos para cargos directivos a las autoridades.

En 1920, el gobernador civil de Barcelona -entonces Salvatierra- había disuelto eventualmente la C.R.T. catalana por no cumplir esos dos requisitos.

Más tarde, el 11 de marzo de 1923, y por motivos no claros, un real decreto había dado extensión nacional a esta exigencia, recordando el deber de toda asociación legal de llevar a los gobiernos civiles los libros de contabilidad y de afiliados, pero imponiendo además que cada una de ellas presentara de nuevo sus reglamentos, estatutos o actas de constitución.

Este segundo requisito pudo obedecer a intenciones que oscilan entre el afán de represión y la simple actualización estadística de las instituciones existentes. En cualquier caso, el propio Gobierno García Prieto, que promulgó el decreto, lo incumplió, al parecer por aceptar el alegato en contra de la U.G.T. y el P.S.O.E. ${ }^{55}$

Ahora, bajo la Dictadura, el 29 de septiembre de 1923, Martínez Anido, subsecretario ya de Gobernación, dirige una circular a los gobernadores civiles en la que insiste en el cumplimiento de aquella misma norma de 11 de marzo anterior.

$Y$ el 3 de octubre, una nueva circular de Gobernación les ordena perseguir como estafa el cobro en el taller de las cotiza-

55 Cf. Comín: Historia del Partido Comunista..., pág. 162 s.; Elorza El anarcosindicalismo..., págs. $126 \mathrm{~s}$. El decreto de 11-III-1923, según la fecha que da Elorza, va en cambio fechado el 12 en la obra de Comín y el 10 en Unión General de Trabajadores. Memoria y orden del día del XVI Congreso..., pág. 18. Tomamos la primera de las tres cifras por decirse basada en la "Gaceta de Madrid». 
ciones de las asociaciones obreras a sus afiliados, que debían de satisfacerlas no allí, sino en el local social de cada agrupación.

Aunque la finalidad es muy poco clara, se ha afirmado que esta segunda medida se encaminaba directamente a la inutilización de los delegados de taller, pieza clave en la organización cenetista. Su texto, sin embargo, contenía una alusión a los libres que resulta hoy por hoy sumamente confusa. Según ella, el cobro en el taller ahora prohibido venía siendo realizado «entre los obreros por delegados de los Sindicatos Libre y Unico, verdaderos profesionales de la explotación de los obreros» ${ }^{56}$. La calificación plantea una incógnita en las relaciones, iniciales al menos, de libreños y Directorio.

La propia circular del 3 de octubre parece precisaba, por último, que las autoridades habrían de incoar auto de procesamiento tanto a los cobradores como a los propios cotizantes si había pruebas de que incumplían lo ordenado. Si no las había (y esto era de una arbitrariedad elemental en principio), debían de obligarles al cambio de residencia en uso de las atribuciones derivadas de la vigente suspensión de garantías constitucionales ${ }^{57}$.

La aplicación de estas dos normas emanadas de Gobernación en septiembre y octubre de 1923 permite por lo demás atisbar ya el criterio distinto con que las nuevas autoridades se enfrentan con socialismo y anarcosindicalismo (cuestión clave para entender, como es sabido, la política social de la Dictadura).

Delegados de la U.G.T. debieron protestar verbalmente de la exigencia de la presentación de contabilidades y libros de afiliados. Según sus propias fuentes. $Y$ como contestación a tal queja se les pidió «se hiciesen por escrito las observaciones necesarias». A este fin, la Comisión Ejecutiva de la Unión General de Trabajadores envió el 8 de octubre un escrito al Gobiemo, firmado por Largo Caballero como secretario, donde ponía de relieve en términos comedidos las dificultades que hallaban los directivos obreros para llevar al día, en los plazos exigidos por la ley, aquellos libros que se les requerían, que habían de elaborar en sus horas libres. Sin que haya datos para explicar por qué ni cómo, el Directorio cedió ante ello para la propia U.G.T. «El resultado general de la gestión ha sido favorable para la

56 Cit. Elorza: El anarcosindicalismo..., pág. 127

57 Sobre toda esta problemática, cf. ibidem, pág. 126 ss. 
organización socialista obrera», diría escuetamente su Comisión Ejecutiva ${ }^{58}$.

No así para la C.N.T.

En consecuencia, el 4 de octubre de 1923 la Federación local barcelonesa de esta entidad acordó pasar a la clandestinidad en vez de someterse a la circular de 29 de septiembre (acaso porque temía comunicar a las autoridades quiénes eran sus afiliados, entre otras razones posibles). En cambio, el Sindicato de la $\mathrm{Me}-$ talurgia y el de Servicios Públicos sí la cumplieron. La división debió cundir. De hecho, parece que comunistas y libres iniciaron una inmediata maniobra de atracción de los cenetistas disidentes ${ }^{59}$, pensando probablemente en los trabajadores que, en desacuerdo pero forzados antaño a formar parte del sindicato único correspondiente, podían sentirse ahora fuertes para abandonarlo en vista de los malos momentos que la Confederación vivía.

En conjunto, la aplicación de aquellas dos medidas de Gobernación debió ser ciertamente diversa: con «diferencias provinciales sensibles», se ha escrito ${ }^{60}$. Y, al menos sobre el papel, el Directorio respetó formalmente a la C.N.T. como organización legal hasta mayo de $1924^{61}$.

Entre el golpe de Estado y esa fecha, la C.R.T. catalana pudo reunir en efecto dos plenos regionales (el de Granollers en diciembre de 1923 y el de Sabadell de 4 de mayo del 24).

En esta relativa lenidad de la política del nuevo régimen (tanto más clara cuanto era dirigida por el máximo contrincante de los grupos de acción anarcosindicalista de años anteriores, Martínez Anido) pudo influir la constatación de que, por sí sola, la Confederación estaba ya desarbolada. Al realizarse el pronunciamiento se hallaba según vimos en "estado de acusada desorganización» ${ }^{62}$. Y a ello hubo de unirse una no precisada represión policial y limitaciones legales indirectas mal conocidas (así las derivadas del establecimiento de la censura militar, que debió permitir la suspensión de publicaciones ácratas) ${ }^{63}$.

58 Unión General de Trabajadores. Memoria $y$ orden del dia del XVI Congreso..., pág. 18.

59 Cf. Elorza: El anarcosindicalismo..., pág. $126 \mathrm{~s}$.

60 Ibidem, pág. 124.

61 De acuerdo con Elorza, no es válida por tanto la afirmación de que la C.N.T. se autodisolvió ante el golpe de Estado (cf. Gerald Brenan: op. cit.).

62 Gómez Casas: op. cit., pág. 143.

63 Según Ramos-Oliveira (op. cit., II, pág. 472), «la dictadura encar- 
De hecho, la anulación drástica de mayo de 1924 siguió a un suceso marginal hasta cierto punto, que debió, sin embargo, hacer temer a las autoridades la reanudación de la guerra social.

El día 7, en Barcelona, fue asesinado a tiros, por gentes que no pudieron ser descubiertas, el zapatero remendón y verdugo de la Audiencia Territorial Rogelio Pérez Ciriaco, partícipe por oficio en la ejecución de reos anarquistas acusados de matar a dos guardias civiles en la Ciudad Condal. Convencido de la culpabilidad de los ácratas en este suceso, el 9 el Directorio ordenó la clausura de las asociaciones anarquistas y cenetistas y la detención de todos sus comités directivos ${ }^{64}$. Anarquistas y C.N.T. quedaban - parece que ahora sí- legalmente eliminados hasta 1930 (aunque investigaciones en curso ponen en duda que la anulación fuera total).

\subsubsection{Anulación del comunismo}

En cuanto al Partido Comunista de España, su oposición a la Dictadura vimos que resultaba clara desde el primer momento. Pero su escasa fuerza y articulación no debieron merecer una sanción formal.

Según un miembro cualificado del grupo, José Bullejos, el movimiento fue relativamente tolerado, sobre todo al comien$\mathrm{zo}^{65}$. Y, en todo caso, si bien los datos son nueva y sumamente confusos y ante todo deshilvanados; parece ser que la acción de la policía bastó para impedir en la práctica cualquier intento de organización del Partido.

Se permitió de hecho que subsistiera su prensa periódica (La Antorcha, órgano del Comité Central en Madrid; La Bande-

celó sin pérdida de momento al estado mayor de los líderes anarcosindicalistas». No lo ratifica Elorza: El anarcosindicalismo..., pág. 125.

64 Cf. García Venero: Historia de las Internacionales..., II, pág. 414 ss.; Comín: Historia del anarquismo..., pág. 54; Id:: Historia del Partido Co munista..., I, pág. 175; Elorza, El anarcosindicalismo..., pág. 142. Todos estos autores coinciden sustancialmente en la versión de los hechos. Sólo difieren en lo que atañe a los individuos detenidos por las autoridades tras el asesinato del verdugo: doscientos según Comín; "un número que desconocemos" según Elorza. E1 dato queda, una vez más, sub iudice.

t5 Cf. Bullejos: op. cit., pág. 53 ss. 
ra Roja, en Bilbao; La Nueva Aurora, en Pontevedra; El Comunista Balear, en Mallorca...) ${ }^{t}$.

Pero los esfuerzos iniciales del periodista y ex oficial del Ejército Oscar Pérez Solís para recomponer el P.C. de E., mediante una reunión de líderes comunistas que convocó en Bilbao, dieron con él en la cárcel desde febrero de 1925 a agosto de 1927 al ser descubierta aquélla por la policía. Con ayuda, al parecer estrictamente espiritual, del padre Gafo, a quien había conocido en 1923 en un hospital de Bilbao donde el periodista se hallaba internado, y con quien siguió tratando en la cárcel, Pérez Solís salió del presidio convertido de nuevo al catolicismo ${ }^{6 ?}$.

De los demás pioneros del comunismo español, para entonces, unos habian muerto o huido y otros disidieron. Se trataba, en principio, de un organismo moribundo, pese a los empeños mostrados desde Moscú para lograr la revitalización en los años siguientes ${ }^{68}$.

66 Cf. Guy Hermet: Les communistes en Espagne (Etude d'un mouvement politique clandestin), París, Armand Colin, 1971, pág. 24.

67 Vid. su propio relato: Oscar Pérez Solís: Memorias de mi amigo Oscar Perea, Madrid, s.i., s.a. [1931?], 346 págs.

68 Insisto en la confusión de los datos. Previa depuración, los hay de interés en las obras citadas de Bullejos, Garcia Venero y Comín. Pero a veces son difícilmente conciliables. Así, Comín (Historia del Partido Comunista..., I, pág. 166 ss.) habla de una verdadera invasión de propaganda comunista durante los años de dictadura. Y en cambio, Maura (op. cit., pág. 307) afirma que en esos años la propaganda de Moscú «no logró trasponer las fronteras españolas». 



\section{LA PARTICIPACION DEL SOCIALISMO}

Sobre aquella filosofía social (si tal cabe decir), nacionalista y cristiana, del nuevo régimen; eliminados el anarquismo, el anarcosindicalismo y el comunismo (al tiempo, en realidad, en que esa eliminación se consigue), el Directorio militar parece hallarse - lo hemos visto- en la disyuntiva: entre la anulación del movimiento obrero legal y su encauzamiento.

Es éste, sin duda alguna, uno de los aspectos de mayor interés en la historia de la Dictadura. Porque, como es sabido, Primo de Rivera opta por el segundo camino. Pero es que, además, lo hace con una pretensión peculiar, que es la que le da su originalidad más acusada respecto a los coetáneos totalitarismos de derecha y en concreto respecto a los fascismos.

No sólo pretende crear un nuevo cauce sindical ajustado a sù estilo de gobierno (cauce que estudiaremos posteriormente), sino que, desde mucho antes, se esfuerza en la atracción del socialismo para esa tarea.

El intento -insisto- es acusadamente original en los años veinte en que ocurre. Pero tampoco parece lícito magnificarlo de antemano. Se desenvuelve hasta cierto punto y a través de un complejo cúmulo de tanteos.

Los primeros pasos, las condiciones del acercamiento y la subsiguiente escisión del socialismo, la frustración de un laborismo español, la normalización del entendimiento y sus resultados serán, por tanto, los temas que hemos de tratar sucesivamente. 


\section{Los primeros pasos}

Queda explicado cómo en principio el P.S.O.E. y la U.G.T. se oponen al régimen militar mediante el aislamiento, desaconsejando cualquier expresión violenta que dé excusa a la represión.

Esta invitación a la mera pasividad lleva de inmediato al planteamiento de una cuestión decisiva: si los socialistas deberán de seguir o no en los cargos representativos que algunos ostentan (como diputados en Cortes, provinciales, alcaldes, concejales o miembros de corporaciones oficiales de cualquier género).

\subsection{PeRmanencia EN las CORPoRaciones oficiales}

Reunida, por ello, la misma Comisión del Partido Socialista Obrero Español, decide afirmativamente. El 22 de septiembre de 1923, en concreto, comunica la decisión por medio de un suelto en El Socialista:

La Comisión Ejecutiva del Partido Socialista ha acordado recomendar a los Diputados provinciales y Concejales socialistas, así como a cuantos correligionarios ostentan car: gos representativos, que continúen en el desempeño de sus puestos, procurando, hoy más que nunca, cumplir en ellos su deber, informando a los trabajadores de la gestión que realicen y no perdiendo el contacto con la opinión pública que les confió su representación.

$\mathrm{Y}$ aún insiste a renglón seguido:

En tanto no se modifiquen las circunstancias, las representaciones socialistas que legalmente tienen asiento en las diferentes corporaciones oficiales deben actuar con absoIuta libertad de movimientos dentro de los cauces legales, sin dar el menor pretexto en resoluciones que, no beneficiando a las ideas, perjudicarán los intereses del proletariado y del país en general. 
En rigor, el criterio manifestado así por el partido es coherente con su desligamiento respecto a los grupos llamados burgueses, plasmado en la ruptura de la Conjunción republicanosocialista de que hablábamos al comienzo. Con o sin Cortes, el Estado monárquico de Alfonso XIII es contrario a lo propugnado por el socialismo español. La novedad introducida en el régimen por el pronunciamiento no ha de afectar, por tanto, al designio de participación de aquél en la lucha política con los medios legales de la organización estatal burguesa.

«Por otra parte -añade un tercer párrafo del escrito, para disipar las acusaciones de criterio estático y divisionista que acaba de formular el 18 de septiembre contra el socialismo el "Comité de acción contra la guerra y la dictadura"-, nadie tendrá derecho a interpretar esta actitud como un acto de solidaridad con hechos que en su día juzgaremos, cuando las libertades públicas sean restablecidas completamente» ${ }^{1}$.

Si esto acuerda la agrupación política socialista (el P.S.O.E.), la postura de la sindical (la U.G.T.) es paralela. También en este caso se impone la conciencia de representatividad, que no ha de supeditarse a la naturaleza del sistema. Actúa en él de hecho, pero no para colaborar con él, sino para realizar la única representación legal posible de los intereses de sus afiliados.

Que no hay en ello colaboración queda claro en el tono con que $E l$ Socialista rechaza la insinuación de $E l$ Sol en ese sentido el 27 de septiembre:

El periódico de inspiración orteguiana no sólo anuncia en esa fecha su propia decisión de coadyuvar «en el trabajo de saneamiento político que realiza el Directorio", sino que se felicita al creer que «la parte más sana del obrerismo español, representada por el Partido Socialista, ... permanece en actitud serena y expectante ante un movimiento que, por lo menos, promete la rectificación de las injusticias pasadas ${ }^{2}$.

$\mathrm{Y}$ esto es justamente lo que el diario obrerista deniega:

El Partido Socialista y la Unión General de Trabajado. res no vislumbran en la acción del Directorio militar el afán de rectificar ninguna injusticia fundamental. Lo creen un movimiento. [Sigue una línea y media en blanco, sin

1 Apud Aunós: Politica social..., pág. 45.

2 Cit. El Socialista, 27-IX-1923. 
duda censurada.] $\mathrm{Y}$, por lo tanto, ni lo ven con simpatía ni cifran en él esperanza alguna.

$\mathrm{Su}$ actitud es rigurosamente independiente: «tiende a impedir que se nos crea unidos por ningún vínculo a lo que acaba de huir». Pero esto no supone «uncimiento a lo que le reemplaza».

Sencillamente, se confiesan insuficientes para «implantar en este instante los propios ideales" y no ven de otra parte una fuerza realmente renovadora a la que apoyar ${ }^{3}$.

La misma impresión de apartamiento, y no de colaboración, resurge ante aquella nota dirigida por el Directorio militar a los trabajadores el 28 de septiembre de 1923, donde según indicábamos les ofrecía una legislación tutelar y les exigía la renuncia a cualquier resistencia que fuera en detrimento de la producción:

Primero, El Socialista la comenta insistiendo en la intangibilidad de la normativa vigente acerca de la jornada de ocho horas (cuya derogación se teme) y en la necesidad de evitar improvisaciones en el momento de legislar en materia social. (Hay cierta posible insinuación incluso, en ello, sobre la conveniencia de un asesoramiento adecuado $-\mathrm{y}$, por tanto, obrero-, semejante al que el Directorio acaba de suscitar al encargar «ponencias sobre temas políticos a diversos titulados especialistas».) Pero además subraya, frente a la nota militar, «que las organizaciones obreras en cuyo nombre hablamos no son de resistencia a la producción, sino de resistencia al capitalismo ${ }^{4}$.

Por su parte, también ante esa nota del Directorio a los trabajadores, se reúnen de nuevo las Comisiones Ejecutivas del P.O.S.E. y la U.G.T. y responden en documento publicado el 1 de octubre que "cualquier intento de menoscabar los derechos consagrados ya por la legislación del trabajo... tendría la consecuencia de producir en la vida del país nuevas complicaciones, de alcance difícil de prever» ${ }^{5}$.

\section{Ibidem.}

4 Ibidem, 29-IX-1923.

5 Apud Partido Socialista Obrero Español. Convocatoria y orden del dia para el XII Congreso..., pág. 91. Algunas citas que se han hecho de este texto modifican ligeramente algunas de sus palabras, aunque no su sentido (así, Aunós: Politica social..., pág. 47, que dice "tenđrá» por «tendría»; o Artola: op. cit., I, pág. 557, «conseguidos» por «consagrados»). Se trata probablemente de errores de imprenta. Por otra parte, el propio Aunós (ibidem) fecha esta contestación de la U.G.T. y el P.S.O.E. en 
No había temor a que esto ocurriera. El talante del régimen militar ante los socialistas comienza a manifestarse en seguida.

En realidad, «a los pocos días del advenimiento del Directorio» se rumoreaba ya "que en el seno de éste se hablaba de buscar una corriente de simpatía por parte de la clase trabajadora y del Partido Socialistas ${ }^{6}$.

No sabemos de quién partió ni por qué prosperó tal idea. Pero podemos aventurar un cúmulo de líneas convergentes, algunas de las cuales han surgido ya aquí:

Primero, y a corto plazo, la serenidad de que hace gala el socialismo ante el golpe de estado parte, según veíamos, de la aseveración de que no existe en España en esos momentos grupo alguno político que tenga fuerza y/o credibilidad suficiente para merecer el sacrificio de los trabajadores en lucha. Es obvio -y explícito- que eso no implica aplauso, sino rechazo de la Dictadura. Pero asimismo es claro que el Directorio se encuentra con una organización que de hecho facilita su asentamiento. Pese a los desprecios verbales, vimos también que instituciones socialistas (así, la madrileña Casa del Pueblo) habían adoptado incluso normas internas de actuación para impedir algaradas de cualquier género. Es, pues, una fuerza que coadyuva en la práctica al mantenimiento del orden.

En segundo lugar, la pasividad de los socialistas en el primer momento se mezcla con una referencia continua a la necesidad de respetar la legislación laboral existente, sin que, en la primera quincena del nuevo régimen, los militares pronuncien su criterio al respecto. El temor a la derogación de lo conseguido conduce ya, según quedó apuntado, a sugerir muy veladamente la posibilidad de un asesoramiento. Con palabras de El Socialista del primero de octubre (momento decisivo en tal tema, como veremos en seguida) se trata de conseguir «que en estos asuntos de organización obrera y de legislación social se proceda con la mayor seriedad, huyendo de toda ligera improvisación y de todo afán innovativo ${ }^{7}$. Hay, por tanto, en principio, cierta predisposición a la ayuda, también en ese aspecto.

30 de septiembre, en tanto que García-Nieto (Bases..., pág. 78) la data en 1 de octubre de 1923.

6 Discurso de Teodomiro Menéndez, apud XII Congreso del Partido..., pág. 73 .

7 El Socialista, 1-X-1923. 
En tercer lugar, los socialistas atribuirían después el acercamiento a la convicción de los gobernantes de «que la única fuerza real, el único obstáculo serio que la dictadura militar puede encontrar en su camino, es la fuerza organizadora de la Unión General de Trabajadores y la fuerza organizada del Partido Socialista» ${ }^{8}$.

La aproximación cristalizará con un episodio que es el primer paso conocido en el acercamiento: la entrevista del asturiano Manuel Llaneza con Primo de Rivera; acontecimiento incidental, pero de clara trascendencia, sobre el que, de otra parte, algunas fuentes impresas pueden arrojar nueva luz. Su importancia y la confusión de lo publicado aconseja reconstruirlo paso a paso.

\subsection{La entrevista LlaneZa-Primo de Rivera}

«Uno de los defensores de esta tesis» de la eficacia de la organización socialista -explicará después Teodomiro Menéndez- es el general Bermúdez de Castro ${ }^{9}$, subsecretario de Guerra en el Directorio, que antes había tenido mando en Asturias y había intervenido aquí en conflictos sociales. Según los mismos socialistas, el general conoce "muy bien las cuestiones obreras de aquella región, sin que los trabajadores tengan queja alguna de la época en que actuó en Oviedo» ${ }^{10}$.

Aureolado con tales títulos, Bermúdez escribe en la segunda quincena de septiembre de 1923 al secretario del Sindicato Minero asturiano y diputado a Cortes Manuel Llaneza para invitarle a conferenciar en Madrid sobre problemas de las minas ${ }^{11}$.

Según la primera versión del propio socialismo, el problema

8 Discurso de Teodomiro Menéndez, apud XII Congreso del Partido..., pág. $73 \mathrm{~s}$.

9 Ibidem, pág. 74.

$10 \quad$ El Socialista, 2-X-1923.

11 Cf. discurso de Teodomiro Menéndez, apud XII Congreso..., pág. 74. Dice a continuación sobre la carta del general Bermúdez de Castro que fue su portador «una persona del viejo régimen; uno de los hombres más significados en el viejo régimen político, que había desempeñado cargos de importancia, incluso el de alcalde de Oviedo». Llaneza rectificó esta versión a lo largo del propio XII Congreso del P.S.O.E.: «la carta se recibió por correo», no en mano, e iba dirigida al propio Llaneza (ibidem, pág. 86).

12 El Socialista, 2-X-1923. 
en cuestión era el de la minería asturiana. La misiva del general explicaba en concreto «que los patronos mineros estaban ya en Madrid al habla con el Directorio, y que éste deseaba no resolver en definitiva sin oír la opinión de la clase trabajadora» $\stackrel{12 .}{.}$

Según Llaneza - posiblemente confundido por el paso del tiempo-, la carta no sólo le pedía que fuese a la capital, sino también «que formara parte de una Comisión que había de investigar las cosas que en Almadén sucedían, nombrado por los obreros de Almadén " ${ }^{13}$. (Llaneza había formulado determinadas acusaciones en las Cortes y en El Socialista contra la administración y dirección estatal de las minas de ese lugar, antes del golpe de estado) ${ }^{14}$.

Se trataba, por tanto, en principio, y en todo caso, de una cuestión puramente técnica $\mathrm{y}$, de otro lado, adecuada a aquel criterio de la U.G.T. y del Partido de continuar participando en los cargos representativos oficiales (aunque, en rigor, lo que se había planteado hasta entonces era la conveniencia de continuar en tales puestos; no la posibilidad de aceptarlos nuevos, ni la de negociar individualmente con el Poder).

Recibida a su nombre la carta, Llaneza creyó prudente consultar la respuesta que había de dar. Y reunió para ello Ia Comisión Ejecutiva del Sindicato Minero asturiano, en Oviedo, el 30 de septiembre ${ }^{15}$. "Sometida esa carta a mis compañeros de Comité - relataría el mismo personaje-, al igual que yo, entendieron que era de suma gravedad, y se acordó venir a Madrid $\mathrm{y}$ ponerlo en conocimiento de nuestra organización. $\mathrm{Y}$ así se hizo» ${ }^{16}$.

13. Discurso de Teodomiro Menéndez, apud XII Congreso del Partido..., pág. 74 .

14 Vid. Partido Socialista Obrero Español. Convocatoria y orden del día para el XII Congreso..., pág. 92, y El Socialista, 2-X-1923.

15 Cf. ibidem.

16 Llaneza, discurso, apud XII Congreso..., pág. 86. De nuevo aquí difieren las versiones de Llaneza y. Teodomiro Menéndez. Según aquél, no sólo se reunió el Comité del Sindicato Minero, sino también la Federación Nacional de Mineros (ibidem) en términos y fecha de los que no hay más noticia. Según Menéndez, la propia Comisión Ejecutiva del Sindicato Minero (él no la denomina Comité) fue la que «acordó que, en efecto, ese compañero viniese a Madrid y se entrevistase con el ministro correspondiente, aun condicionando que en la reunión se pudiera tratar de otras cuestiones que las puramente mineras» (ibidem, pág. 74). Esta última versión niega implícitamente el paso intermedio, que es de suma importancia para el problema posterior de las responsabilidades que se debatió en el XII Congreso. Me refiero a que, de acuerdo con Llaneza, 
No se hizo en realidad así:

En verdad, lo que el Comité asturiano acordó fue responder directamente a Bermúdez de Castro para notificarle que su secretario, en efecto, salía hacia la capital ${ }^{17}$. Y, llegado a Madrid en la mañana del 2 de octubre ${ }^{18}$, lo primero que éste hizo fue acudir -a las diez- al ministerio de la Guerra ${ }^{19}$, sin consultar a la Ejecutiva de la U.G.T.

No sabemos si llevaba en rigor la intención o el mandato de realizar tal consulta, o si el Sindicato Minero y él actuaron desde el comienzo al margen de la Comisión de la Unión General y con idea de prescindir de ella. Llaneza alegaría más tarde que wle fueron a buscar en el coche oficial del ministro de la Guerra a la estación y se lo llevaron al Palacio de Buenavista, sin que tuviera ocasión de conversar con nadie ${ }^{20}$.

Pero la trascendencia de la visita no había de estribar en tal formalismo (por sí solo importante), sino en que su interlocutor fue el propio Primo de Rivera.

De nuevo según Llaneza, una vez en palacio fue introducido ante el dictador ${ }^{21}$, al parecer inesperadamente. Conforme a la primera y un poco imprecisa versión socialista, oficiosa, en el ministerio le aguardaba Bermúdez de Castro, con quien cambió «impresiones acerca de lo que deseaba conocer el Directorio». Pero también «en el despacho del ministro de la Guerra estaba el general Primo de Rivera».

De acuerdo con este primer relato -el de El Socialista del propio 2 de octubre-, tan sólo hablaron acerca de la situación laboral en la minería del carbón y sobre la posibilidad de que Llaneza colaborase en una comisión técnica para su estudio. En concreto, el dictador le preguntó «su opinión respecto a las condiciones de trabajo de los mineros de Asturias». Y aquél expuso «sus opiniones, ya conocidas, acerca de las explotaciones mineneras, de las malas condiciones en que hay que extraer el car-

la Comisión del Sindicato no habría decidido sobre la entrevista con el ministro, sino sobre la necesidad de consultar primero a la Comisión Ejecutiva de la U.G.T.

17 Cf. El Socialista, 2-X-1923.

18 Es errónea la fecha 1 de octubre que dan varios autores. La equivocación parte seguramente de la Convocatoria y orden del día para el $X I I$ Congreso..., donde se introduce el error.

19 Cf. El Socialista, 2-X-1923.

20 Discurso de Indalecio Prieto, apud XII Congreso del Partido..., pág. 137.

21 Cf. discurso de Llaneza, ibidem, pág. 86. 
bón, del perfeccionamiento que poco a poco se introduce en las minas asturianas y de los defectos de administración que algunas Empresas padecen, todo lo cual hace que el rendimiento del obrero parezca menor del que es en realidad».

Fue entonces cuando Primo de Rivera «habló a Llaneza del mal estado de la mina de Almadén, diciendo que se propone proceder a sanear todo lo que allí hay, y [le] preguntó su opinión..., invitándole a formar parte de una Comisión de ingenieros que irá a reconocer aquella mina» ${ }^{2}$. Conforme siempre a la información socialista, la iniciativa había partido de un grupo de comisionados de esa explotación meridional, que, el mismo día 2, momentos antes de la entrevista con el activista asturiano, habían tratado esa problemática con el dictador. Le habían asegurado "que se estudiarían estos problemas por una Comisión especial de ingenieros» (la notificada luego al secretario del Sindicato Minero de Asturias) y le «hicieron constar su especial interés de que Llaneza, como representante obrero, formase parte» de ella.

En su conversación con Primo de Rivera, el líder asturiano acepta el nombramiento «en principio, para proceder siempre de acuerdo con los mandatos de la organización obrera» ${ }^{23}$, al tiempo en que ratifica "las denuncias hechas en El Socialista acerca de las minas de Arrayanes y de[1 propio] Almadén, en donde la Dirección no se actúa con acierto ni ha bajado a la mina en siete años».

Todavía se refiere el dictador a la imposibilidad de «continuar el régimen de primas para la exportación del carbón» (tema enraizado en la difícil coyuntura hullera de los años veinte). $\mathrm{Y}$, como de pasada, manifiesta a Llaneza «que quizá :tenga necesidad de volver a cambiar impresiones» con él.

Como remate (que en rigor no tenía por qué desprenderse de la conversación, tal como vemos iba reseñada), El Socialista ponía este punto final a la noticia: «La impresión que se deduce de lo que opina el Directorio en relación con el movimiento obrero es que no corre peligro ninguna conquista legítima de las alcanzadas por los trabajadores» ${ }^{24}$.

\footnotetext{
2 El Socialista, 2-X-1923.

23 Ibidem, 3-X-1923.

24 Ibidem, 2-X-1923.
} 
En la entrevista, pues, debió hablarse de más asuntos.

$Y$ es que, en verdad, la visita pudo tener un mayor contenido. Según una versión jamás comprobada, pero verosímil (la del también socialista Ramos-Oliveira), la realidad es que en aquella ocasión hubo más: Primo de Rivera «le aseguró que el nuevo régimen respetaría todas las ventajas sociales conseguidas para los obreros. Los sindicatos seguirían funcionando. Las tímidas leyes sociales dictadas por la oligarquía se mantendrían y la dictadura promulgaría otras más favorables aún para el proletariado industrial. Llaneza salió de la entrevista satisfecho. 'No hay nada que temer', vino a decir en público ${ }^{25}$.

Prieto dudaba incluso, más tarde, "si fue en aquella entrevista en donde ofrecieron carteras ${ }^{26}$.

Es asimismo verosímil la respuesta que Llaneza dijo haber dado al dictador ante estas invitaciones:

«Que a mí no se me podía hablar absolutamente de nada que se refiera a política.»

Textualmente, le respondió:

"Yo estoy dentro de la organización obrera [la U.G.T.]; pero en el Partido, soy un soldado disciplinado del mismo, y el Gobierno, si quiere oír la opinión del Partido en lo que afecta a la política, debe dirigirse al Comité directivo que tenemos» ${ }^{27}$; contestación que desde luego no permite suponer que su interlocutor se limitó a ofrecerle un puesto en la Comisión minera.

En cualquier caso, fue después y no antes de esta entrevista cuando el socialista acudió a la consulta ante la Comisión Ejecutiva de la Unión General ${ }^{28}$.

Antes aún de reunirse ésta, pero después de la conversación con el dictador, Llaneza - según Indalecio Prieto- «nos explicó a Saborit y a mí lo sucedido, yo le dije, con franqueza, que me parecía mal. Se reunió aquella tarde la Comisión [Ejecutiva del

\footnotetext{
25 Ramos-Oliveira: op. cit., II, pág. 471.

26 Apud XII Congreso..., pág. 137.

27 Ibidem, pág. 86.
}

28 Llaneza, ibidem, pág. 80, da a entender lo contrario (que la Comisión Ejecutiva del P.S.O.E. fue consultada antes) cuando, en términos imprecisos (que a la letra podían referirse incluso a la Comisión del Sindicato Minero Asturiano), dice: «En el Comité hubo discrepancias por parte de algunos elementos, a pesar de lo cual se aprobó que yo fuera a esa entrevista solamente para tratar de asuntos que afectaran al problema minero.» Pero, a juzgar por las rectificaciones posteriores recogidas, ibidem, no fue así: por los motivos indicados, la entrevista se habia celebrado ya cuando la Comisión se reunió. 
P.S.O.E. con la de la U.G.T.], y ya nos dividimos al apreciar la visita».

Además, sin terminar aún esta reunión de la tarde del 2 de octubre, «cuando estábamos deliberando sobre esto..., El Socialista, que se publicaba entonces por la noche, apareció con la referencia de la visita de Llaneza presentada de forma llamativa... con un titular a dos columnas que decía 'Llaneza ha visitado al jefe del Directorio', como un acontecimiento trascendental en la vida nuestra" ${ }^{20}$.

Pese a que este hecho no obedeció quizás a segundas intenciones, sino a la primera impresión causada por la entrevista en los redactores del diario, los titulares alarmaron a Pablo Igle$\operatorname{sias}^{30} \mathrm{y}$ desde luego a Indalecio Prieto.

Todavía en la reunión de la Comisión del 2 de octubre de 1923, «yo me quejé - diría Prieto- de que esto no era lógico, y ya no nos pusimos de acuerdo respecto a la versión que se había dado de la visita».

Era preciso de otra parte tomar postura sobre ella por medio de un escrito público. «Unos creíamos que se debía hacer una nota más rotunda que la que se hizo y se redactó, ... con la cual estuvimos disconformes, por estimarla floja, algunos compañeros, muy pocos, entre ellos yo, que quedamos en minorias ${ }^{31}$.

La nota definitiva en cuestión, publicada en El Socialista el 3, estaba llena de significación, aunque en rigor no hacía más que sancionar a posteriori la gestión del líder asturiano.

A instancias del compañero Manuel Llaneza, secretario del Sindicato Minero de Asturias, se reunieron ayer las Comisiones Ejecutivas del Partido Socialista y de la Unión General, a las que pidió aquél se le señalara la línea de conducta ante invitación por él recibida para conferenciar con el general Primo de Rivera.

Las Comisiones Ejecutivas conociendo los términos en que se desarrolló la entrevista celebrada ayer mañana, y en su deseo de que ante las excepcionales circunstancias estos actos no puedan prestarse al equívoco de que significan colaboración o asesoramiento, acuerdan que Llaneza continúe circunscribiendo su intervención con el Directorio militar a las cuestiones mineras de índole inaplazable ${ }^{32}$.

29 Prieto, ibidem, pág. 137.

30 Cf. Saborit, ibidem, pág. 158.

31 Prieto, ibidem, pág. 137.

32. Cit. ibidem. 


\subsection{LA DIVISIÓN DEL SOCIALISMO ESPAÑOL}

De este episodio del 2 de octubre de 1923, mucho más que una anécdota, se siguen dos hechos de interés al menos: el comienzo de la leyenda sobre la colaboración del socialismo con la Dictadura y el comienzo también de la escisión en aquél.

Respecto al primer punto, parece que la entrevista del dirigente asturiano con Primo de Rivera no cerró ninguna misteriosa alianza entre el Directorio y los socialistas, como una parte de la historiografía daría a entender. No parece que Llaneza se comprometiera a nada. No tenía poder para hacerlo.

Pero otra cosa es que el propio Directorio se encargase seguidamente, si lo hizo, "de extender ese equívoco... [de] que hay una inteligencia entre los elementos directivos de la organización obrera española y el Gobierno" ${ }^{33}$. Y es asimismo otra cuestión que la actitud del dictador suscitase un talante moderado y de hecho colaboracionista en determinados dirigentes socialistas (el primero, el mismo Llaneza, que ya el 4 de octubre de 1923 tenía prevista una nueva conversación con el general ${ }^{34}$, a dos días de la primera).

En segundo lugar, y acaso por esta última postura, la entrevista sí fue en cambio piedra de toque para el inicio de la profunda división interior del P.S.O.E., que marca su historia hasta 1929: la división entre una mayoría no colaboracionista, pero expectante y partidaria de mantener la función representativa sobre la puramente política, y una minoría propensa al enfrentamiento directo con el sistema.

Ya desde ese momento inicial dirigen la primera Andrés Saborit, Largo Caballero y Julián Besteiro (todavía muy lejos del enfrentamiento de los dos últimos), con la aquiescencia de Pablo Iglesias, que apenas parece participar en las decisiones de estos últimos años de su vida, externamente al menos.

Encabezan la segunda Indalecio Prieto y el asturiano Teodomiro Menéndez.

Que la escisión surge ahora (sin romper la unidad organiza-

\footnotetext{
33 Gabriel Morón, ibid, pág. 114.

34 Vid. El Socialista, 4X-1923.
} 
tiva) lo afirmaría Prieto taxativamente: «la discrepancia la motivó por primera vez la visita del compañero Llaneza al general Bermúdez de Castro " ${ }^{35}$; «este es — según Menéndez- el punto inicial y de partida del Directorio para poder vencer la resistencia que la clase trabajadora y el Partido pueden ofrecer ${ }^{36}$.

El motivo del desacuerdo parece ciertamente fruto más de una actitud política que de un criterio coherente. De modo unánime, en septiembre de 1923, las Comisiones Ejecutivas del P.S.O.E. y de la U.G.T. habían aconsejado según vimos permanecer en sus puestos a los afiliados con cargos oficiales representativos, que por tanto ostentaban un nombramiento democrático al que nada afectaba el tipo de sistema político en que actuasen. En rigor, si, como parece, la designación de Llaneza para la comisión minera iba a ser realizada por los trabajadores de Almadén, el caso era semejante. Pero un sector del Partido comenzaba a inquietarse ante lo que ese comportamiento implicaba en la práctica, sobre todo desde el momento en que anarcosindicalistas y comunistas habían definido con claridad no solo su postura beligerante, sino la diferencia de esta con la «estática» del socialismo.

Desde los primeros atisbos de entendimiento fáctico, no sólo estos sectores, sino fuerzas de orden, como tales significadas, habían empezado además a denunciar lo que consideraban ya verdadero acuerdo. "El Socialista - escribe por ejemplo El Debate a comienzos de octubre de $1923-, \ldots$ está tratando al Directorio militar con consideraciones que no recordamos haya guardado a Gobierno alguno» ${ }^{37}$. Sus políticos «logran -insiste el diario católico al comenzar 1924- un trato de favor en los centros oficiales, que se traduce en consideraciones desproporcionadas y en otros beneficios materiales que no es preciso puntualizar» ${ }^{38}$.

Por lo demás, en aquellas semanas iniciales de Dictadura (atiéndase a esta precisión cronológica), la minoría disidente, comandada por Indalecio Prieto, dio muestras de moverse más por temor a las consecuencias que porque considerase incumplidos los acuerdos adoptados antes por las Comisiones Ejecutivas sobre el mantenimiento en aquellos cargos.

En cuanto a la mayoría, tampoco debía estar aún muy segu-

35 Prieto, apud XII Congreso..., pág. 136.

36 Ibidem, pág. 74 .

37 Cit. El Socialista, 4X-1923.

38 Cit., ibidem, 8-1-1924. 
ra de los propósitos del nuevo régimen y de la actitud a adoptar en el futuro por tanto. En fecha imprecisa, pero en torno a los días de la entrevista y sus consecuencias, la U.G.T. presionó sobre la Oficina Internacional del Trabajo para que adoptara «un acuerdo por el que Primo de Rivera comprendiese la existencia de una solidaridad internacional, ejercida a través de la S[ociedad] de las N[aciones]».

Buscaba, en definitiva, respaldo exterior frente a las hipotéticas medidas antisindicales que se temían del Directorio.

Y así logró, aún en octubre de 1923, una resolución de la O.I.T. «íntimamente trabada con la circunstancia española» ${ }^{39}$. Según ella, urgía "proceder al estudio documental más completo sobre la situación que existe en todos los países miembros de la Organización Internacional del Trabajo, en lo que se refiere a la aplicación» de la libertad sindical ${ }^{40}$.

\section{Límites de la participación socialista}

Entre septiembre y octubre de 1923, se fijan los puntos básicos de la política social de la Dictadura: no sólo sus fundamentos doctrinales y la anulación de las fuerzas consideradas corrosivas, sino el inicio de lo que cabe considerar intento de recuperación del socialismo para la obra de gobierno.

Hemos visto también cómo esta recuperación triunfa, desde el momento en que la mayoría de los dirigentes del P.S.O.E. y de la U.G.T. supeditan sus preferencias políticas a su función representativa.

Ahora es preciso concretar de qué forma se lleva a cabo la participación consiguiente en el poder y hasta dónde alcanza.

\subsection{LA táctica deL Durectorio}

Por parte del Directorio, la sinceridad y el propio alcance de sus disposiciones no tardaron en exteriorizarse. Desde el otoño mismo de 1923 se aprecia un sistemático empeño de la Ad-

39 García Venero: Historia de las Internacionales..., II, pág. 428 s.

40 Cit., ibidem, II, pág. 429. 
ministración militar en realizar al máximo la atracción de los socialistas por medio de una práctica alentada si no sugerida por las consecuencias de la entrevista con Llaneza y su aceptación del nuevo cargo en la Comisión minera.

Me refiero a la táctica de ofrecer a aquellos puestos en organismos estatales, desde los que de hecho participen en la gobernación del país. Ya no sólo se trata, por lo tanto, de la continuación en los que detentan, sino de la ocupación de otros. $\mathrm{Y}$, éstos, unas veces es claro que proceden de una oportunidad derivada de normas legales con distinto fin; pero en otros cabe pensar que el Directorio busca expresamente la manera de abrir un cauce nuevo a los socialistas.

Entre los primeros (cargos de nueva adjudicación, pero derivados de una normativa general, no explícita ni intencionalmente favorable a los socialistas por fuerza), destaca en primer lugar, en la cronología, la decisión publicada por la Gaceta del primero de octubre de 1923 de destituir a todos los concejales de los ayuntamientos y sustituirlos automáticamente por los llamados «vocales asociados» que existían en los mismos. A instancias de la Agrupación de Pueblonuevo del Terrible, la comisión Ejecutiva del P.S.O.E. se pronuncia el 3 a favor de que los vocales asociados que sean socialistas acepten tal sustitución y con ello el cargo de concejales ${ }^{41}$. Lo hacen cuarenta y seis, distribuidos de esta manera ${ }^{42}$ :

\begin{tabular}{|c|c|c|}
\hline Azuaga $\ldots \ldots \ldots \ldots \ldots \ldots \ldots$ & 1 & Portillo $\ldots \ldots$ \\
\hline 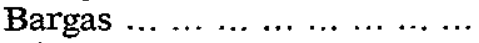 & 2 & Pozoblanco .. \\
\hline $\begin{array}{cccccccc}\text { Bélmez } & \ldots & \ldots & \ldots & \ldots & \ldots & \ldots & \ldots\end{array}$ & 5 & Pueblonuevo del Terrible ... \\
\hline 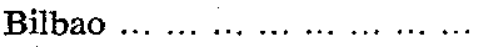 & 1 & Puente Genil ... \\
\hline Cáceres $\ldots \ldots \ldots \ldots \ldots \ldots \ldots$ & 1 & San Martín del Rey Aurelio. \\
\hline $\begin{array}{llllllll}\text { Hueria } & \ldots & \ldots & \ldots & \ldots & \ldots & \ldots & \ldots\end{array}$ & 1 & $\begin{array}{llllll}\ldots & \ldots & \ldots & \ldots & \ldots & \ldots\end{array}$ \\
\hline 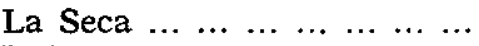 & 2 & Sotillo de Ia Ribera ... \\
\hline $\begin{array}{llllllll}\text { León } & \ldots & \ldots & \ldots & \ldots & \ldots & \ldots & \ldots\end{array}$ & 1 & Tarazona de la Mancha ... ... \\
\hline $\begin{array}{lllllll}\text { Madrid } & \ldots & \ldots & \ldots & \ldots & \ldots & \ldots\end{array}$ & 1 & $\begin{array}{lllllll}\text { Turleque } & \ldots & \ldots & \ldots & \ldots & \ldots & \ldots\end{array}$ \\
\hline $\begin{array}{lllllll}\text { Madrigueras } & \ldots & \ldots & \ldots & \ldots & \ldots & \ldots\end{array}$ & 1 & Villena. \\
\hline Málaga $\ldots . . . . .$. & & \\
\hline
\end{tabular}

Entre los segundos (cargos orientados de forma expresa a servir de vehículo al socialismo), la Comisión ofrecida a Llaneza

41 Cf. Partido Socialista Obrero Español. Convocatoria y orden del dia para el XIl Congreso..., pág. 92.

42 Ibidem, pág. 365 . 
el 2 de octubre de 1923 será seguida el 3 por una oferta relacionada con la O.I.T. En tal fecha, en efecto, la Secretaría de la Unión General recibe una comunicación del ministerio de Trabajo, Comercio e Industria. Se notifica en ella que ante la reunión inmediata - prevista para el próximo 22 - de la V Conferencia de la Oficina Internacional del Trabajo, el Directorio mantiene el criterio de que, "como en las reuniones anteriores..., la Delegación obrera esté designada por la organización más representativa, según dispone el reglamento de dicha Conferencia general». Y, a tal efecto, la Comisión Asesora del Gobierno y de la representación de España en la O.I.T. ha decidido que sea la U.G.T. la que nombre al delegado y a los dos asesores técnicos que componen la representación ${ }^{43}$.

Se inicia así una línea de acción de la Dictadura que, so capa de continuismo, va a trocarse en seguida en política sistemática.

\subsection{LAS CONDICIONES PARA LA PARTICIPACIÓN}

Ante esa práctica, la primera reacción de la U.G.T. (principal entidad afectada, porque se trata en la mayor parte de los casos de cargos de tipo sindical o laboral, no de contenido directamente político) es la de endurecer, fijándolas, las condiciones para aceptarlos.

De hecho, las condiciones van a ser dos:

Exigirá, por una parte, que los cargos que se le ofrezcan sean realmente representativos; esto es: desempeñados por sujetos elegidos por sufragio o por la propia U.G.T., no por las autoridades.

$\mathrm{Y}$ en segundo lugar impondrá que, si ese ofrecimiento de cargos se hace expresamente a la Unión General, no se equipare a esta entidad socialista con otras asociaciones obreras ofreciéndoles puestos semejantes.

Este segundo extremo queda claro en noviembre, todavía en 1923. El 24, la U.G.T. recibe una real orden del Ministerio de Estado que pide designe en su seno un representante «para la Comisión que había de proponer al Gobierno la estructura, funciones, personal técnico y administrativo, presupuesto y regla-

43 Apud El Socialista, 4-X-1923. 
mentación general que, a su juicio, había de regir con carácter permanente en otra que se encargaría del estudio y preparación de los convenios comerciales». (Esta comisión había de ser en concreto el futuro Consejo de la Economía Nacional, pieza importante en ese sector de la política dictatorial.)

En verdad, se trataba de un puesto semejante al ofrecido a Manuel Llaneza en octubre. Pero el Comité Nacional de la U.G.T. lo rechazó alegando «que en dicha Comisión se daba también igual representación a los Sindicatos católicos de obreros» ${ }^{44}$. En el escrito consiguiente dejó constancia explícita de su renuncia «a compartir con los expresados elementos una representación que, en justicia, a esta Unión General solamente le corresponde ostentar» ${ }^{45}$.

El Directorio no cejó en el empeño por esta razón:

Por las mismas fechas, el 29 de noviembre de 1923, el gobernador militar de Madrid duque de Tetuán visitaba simbólicamente la Casa del Pueblo de aquella villa, domicilio de la U.G.T. y del P.S.O.E., para informar después públicamente que los obreros recibían en ella una formación adecuada ${ }^{46}$.

Continuaron del mismo modo las relaciones oficiosas con Manuel Llaneza, que a comienzos de enero de 1924 ya había sido llamado otra vez por lo menos por el Directorio para tratar con representantes patronales acerca de la cuestión de las «primas a los carbones y otros asuntos mineros» ${ }^{47}$.

Pero, en los mismos días, aparecen nuevos problemas, que exigen un criterio más claro.

Suspendidos oficialmente los ayuntamientos de toda la península el primero de octubre de 1923, habian sido reconstituidos, según advertimos, con los vocales asociados. Pero en algunos casos los correspondientes gobernadores civiles intervinieron además con el nombramiento de nuevos concejales.

En Vigo, en concreto, y en el otoño de 1923, el gobernador otorga ese cargo a uno de los individuos que habían sido ediles ya hasta el 1 de octubre, el socialista Botana, dándole plazo hasta el 5 de diciembre para que acepte o no. Sin criterio sobre

44 Unión General de Trabajadores. Convocatoria y orden del día del XVI Congreso..., pág. 10.

45 Resolución del Comité Nacional de la U.G.T., ibidem, pág. 10.

46 Cf. García Venero: Historia de las Internacionales..., II, pág. 419.

47 Aunós: Política social..., pág. 47. 
lo que ha de responder, Botana lo consulta a la Comisión Ejecutiva del P.S.O.E. La Comisión se reúne el 3 de diciembre al respecto y registra un empate en la votación ${ }^{48}$. Aconseja por ello en carta al interesado que "ponga el caso en conocimiento del Partido local, y con lo que éste acuerde, así como con las razones que tenga para aceptar o para negarse, que oficialmente... escriba» a la propia Ejecutiva para que ésta adopte la decisión final ${ }^{49}$.

Para entonces, no obstante, en vista del apremio del plazo dado por el gobernador civil, el Comité local de Vigo ya ha decidido que Botana acepte la concejalía, por juzgar que es de hecho una reposición en un puesto que ocupaba y no un nombramiento nuevo.

Así lo notifican por telegrama a la Comisión. Examina ésta la situación otra vez ${ }^{50}$; de nuevo se divide, empata, y decide el empate Blázquez ${ }^{51}$, pero a favor de que Botana rechace el cargo en cuestión. Defienden este criterio - junto al mismo BlázquezBesteiro, Largo Caballero, Pascual y Fernández Quer, frente a Lucio Martínez, Núñez Tomás y Saborit, que se pronuncian por la aceptación debatida. De nuevo a posteriori, los nombres de uno y otro sector revelan que la escisión del socialismo dista de haber cuajado. Caballero y Besteiro defenderán más adelante lo que ahora repudian.

Por lo demás, la Ejecutiva comunica a Vigo la decisión. Mas, para entonces, y según la versión de la Agrupación gallega, al parecer de nuevo "se había reunido allí el Partido, y decidido por mayoría que el compañero Botana aceptase el cargo, por considerarlo una reposición».

Tratado luego el tema por el Comité Nacional del P.S.O.E., $\mathrm{y}$ vistos «los hechos consumados y la buena fe de los correligionarios de Vigo..., se acordó por unanimidad que el Partido Socialista de Vigo libremente examinara lo que más convenía hacer

48 Cf. Partido Socialista Obrero Español. Convocatoria y orden det dia para el XII Congreso..., pág. $94 \mathrm{~s}$.

49 Reproducida, ibidem, pág. 94.

50 Cf., ibidem.

51 Cf. Prieto, apud XII Congreso..., pág. 138. Prieto habla en primera persona del plural al relatar estos hechos. En la relación de individuos presentes que aparecen en la fuente que cito en la nota inmediata, Prieto está ausente, sin embargo. 
en beneficio de las ideas». Botana, en consecuencia, siguió en el ayuntamiento, en seguida como teniente de alcalde ${ }^{52}$.

Estos disentimientos - afirmaría luego Indalecio Prieto«no tuvieron ninguna trascendencia pública» ${ }^{53}$. Pero, por esto mismo, el criterio a seguir continuó siendo incierto.

En tal situación, la necesidad de fijar una regla clara lleva a una nueva reunión del Comité Nacional del P.S.O.E. en 9 de enero de 1924. En ella, y en contra de una carta de Prieto a Besteiro, que no conocemos, se aprueba la gestión de la Comisión Ejecutiva $\mathrm{y}$ "por unanimidad se decide que los socialistas no acepten cargos públicos que no sean de elección popular o en representación oficial de organismos obreros y designados por éstos directamente, rigiendo este acuerdo con carácter nacional a partir del momento en que se adopta» ${ }^{54}$.

Esta última salvedad permite que sigan en los suyos hombres como Botana. Y, de otra parte, se supone que sí conviene aceptar los cargos que respondan a tales requisitos.

Así, en el mismo pleno del P.S.O.E. y la U.G.T. en que esa regla es adoptada, también se acuerda «invitar a las Agrupaciones y Sociedades Obreras para que, cuando se conozca el nuevo régimen municipal, organicen... la intervención del Partido en los Ayuntamientos, preparando debidamente al Cuerpo electoral $\$ .55$.

Nuevas cuestiones irán sumándose, por lo demás, para ahondar y a la larga exteriorizar la escisión que va perfilándose en el socialismo.

De modo significativo, el 12 de enero de 1924 el Comité Nacional de la U.G.T. aprueba una felicitación expresa a los representantes socialistas en los Institutos de Reformas Sociales y Nacional de Previsión "por la obra beneficiosa para los trabajadores que se viene realizando en dichos organismos» ${ }^{56}$.

52 Cf. Partido Socialista Obrero Español. Convocatoria y orden del dia para el XII Congreso..., pág. 95.

53 Apud XII Congreso..., pág. 138.

54 Apud Partido Socialista Obrero Español. Convocatoria y orden del dia para el XII Congreso..., pág. 96.

55 Apud El Socialista, 15-I-1924.

56 Aunós: Politica social..., pág. 48. 
El 31, es el propio presidente del I.N.P., José Marvá, quien dirige una carta pública a los vocales obreros de la Comisión Paritaria del segundo de los institutos citados, a raíz de un artículo sobre el retiro obligatorio, aparecido en El Socialista y firmado por ellos. «... me complace expresarles - dice Marvá sobre la gestión de esta representación obrera en ese organismo- que lo está haciendo con tal solicitud, perseverancia y espíritu de ponderación, que merecen el sincero elogio que tengo la satisfacción de dirigirles» ${ }^{57}$.

Los vocales socialistas responden, también en carta pública el 1 de febrero, en términos visiblemente afectuosos. Se refieren «al régimen de previsión popular que con tanto cariño, perseverancia y entusiasmo vienen difundiendo hace años por el país usted y las demás prestigiosas personalidades que están al frente del Instituto Nacional de Previsión». Recuerdan «el interés que el digno presidente del Instituto pone al servicio de la clase trabajadora en toda su actuación, divulgando sus grandes conocimientos, tanto en las Corporaciones sociales de que forma parte como en la tribuna de los Centros Obreros». "Los que con usted a la cabeza dirigen el Instituto Nacional de Previsión, además de dar vida a esta progresiva institución, orientándola con sumo acierto, han sabido iniciar gradualmente la obra de la previsión popular con firmes avances» ${ }^{58}$.

Paralelamente, el parecer por estas mismas fechas, Prieto se ve forzado a protestar ante Andrés Saborit de la satisfacción (en la que debió ver implicaciones de colaboracionismo, consciente o no) con que los redactores de El Socialista refieren que, en tal o cual lugar, la autoridad ha encarcelado a algún alcalde o concejal del régimen parlamentario. El director del diario le da la razón, pero defiende la necesidad de "respetar la autonomía de las Agrupaciones» de donde las noticias proceden ${ }^{59}$.

El Directorio, por su parte, insiste en penetrar por la brecha abierta.

Por real orden de 17 de enero del 24, crea el Servicio de Información Telegráfica Comercial, cuyo consejo de administración solicita luego de la U.G.T. el nombramiento de un representante suyo que coopere en la organización del propio Servicio. El

7 Apud El Socialista, 31-I-1924.

58 Reproducida, ibidem, 1-II-1924.

59 Apud XII Congreso..., pág. 138 s. 
designado fue Lucio Martínez (que, en 1928, no había tomado posesión, sin embargo, "por no haber sido citado todavía») ${ }^{60}$.

Hay aún, desde luego, pasos en falso:

Un decreto de 8 de marzo constituye el Consejo de Economía Nacional, de resultas de la ponencia elaborada por aquella comisión de noviembre anterior a la que la U.G.T. negó su representante por haberlo reclamado también de los sindicatos católicos. Ahora vuelve a ocurrir lo mismo. En el nuevo Consejo se concede un escaño a la U.G.T. y otro a los sindicatos confesionales. La U.G.T. lo rechaza por tanto ${ }^{61}$.

«Según acuerdos adoptados por la Unión General -razona El Socialista-, sus representantes no participarán en los organismos en que se dé representación a los Sindicatos amarillos, que ni tienen fuerza ni representan ninguna idealidad.

Eso del catolicismo es el rótulo para cubrir la mercancía» ${ }^{62}$.

La colaboración es, pues, hasta este momento, consecuencia al menos teórica del afán representativo de la U.G.T., que hace en ello abstracción de la forma de gobierno.

Hay un instante, sin embargo, en que en el propio socialismo parece haberse sopesado la posibilidad de ir más allá.

\section{Planteamiento de un laborismo español}

Hay, en efecto (y es este un hecho apenas conocido) un momento en que parece haberse pensado en la posibilidad de convertir la praxis que acabo de describir en verdadera colaboración, en un sentido semejante al del laborismo británico.

\subsection{EL IMPACTO DE LAS ELECCIONES INGLESAS}

Debió animar a esto, precisamente, el triunfo del Partido Laborista en las élecciones inglesas del 6 de diciembre de 1923. En

60 Unión General de Trabajadores. Convocatoria y orden del dia del XVI Congreso..., pág. 11.

61 Cf. ibidem, pág. 10.

62 El Socialista, 1-IV-1924. 
ellas, como en el año 1922, se mantiene la mayoría conservadora, pero con sólo 250 escaños, en tanto los laboristas pasan de 142 a 192 diputados y los liberales alcanzan 155. La subsiguiente formación de una coalición lib-lab lleva a la presidencia del Consejo de Su Majestad, por primera vez, a un socialista: Ramsay Mac Donald.

La coalición lib-lab es derrotada en seguida, en nuevas elecciones del otoño de 1924, en que la representación laborista se reduce a 151 escaños. Pero el mero triunfo inicial basta para mostrar la posibilidad inmediata de llegar al poder ${ }^{63}$.

Y esa misma esperanza aletea en España:

Traduciendo a Jean Longuet, El Socialista lo interpreta, a comienzos de enero de 1924, como el acontecimiento «más considerable que se haya producido en Europa desde las revoluciones rusa y alemanas de $1917-1919^{64}$.

Oportunamente (Lenin fallece al empezar también el año 1924), Manuel Cordero contrapone Inglaterra y Rusia en las mismas páginas: Lenin y Mac Donald - escribe- persiguen «ideales hermanos». Pero se enfrentan en el respeto a la libertad. $Y$ esto, no por error de uno $\mathrm{u}$ otro. Sino porque el método revolucionario a utilizar en cada país difiere. "En cada caso y en cada pueblo hemos de aplicar aquellos procedimientos que [aconseje] nuestra razón crítica, hecha a base de la experiencia que los aciertos y los errores, que también enseñan, nos den para seguir el camino que fatalmente le está trazando a la Humanidad para llegar a estados de mayor perfección social.» Todavía el escritor socialista se mantiene en el punto medio de afirmar su deseo de «llegar al fin utilizando los principios liberales y democráticos», pero también su decisión de no desechar «la eficacia de la acción de la fuerza".

Es curioso que su mayor esperanza en el socialismo democrático se funda todavía, en 1924, en el viejo error de la profecía marxista:

63 Para el estudio del ascenso del laborismo británico, vid. Ross McKibbin: The Evolution of the Labour Party 1910-1924, Londres, Oxford University Press, 1975, y Maurice Cowling: The Impact of Labour, 1920-24: The Beginning of the Modern British Politics, Nueva York, Cambridge University Press, 1971.

Los resultados de estas elecciones pueden consultarse en la obra de F. W. S. Craig: British Parliamentary Election Results 1918-1949, Glasgow, Chichester, 1969.

64 Jean Longuet: El Partido Laborista, en el umbral del Poder, apud El Socialista, 8-I-1924. 
«... $\dot{\text { en }}$ dónde hay más probabilidades para que tenga eficacia la Revolución social? Aquí la afirmación puede hacerse rotundamente: en Inglaterra.

Son los países industriales, según Marx, y no los agrícolas, los que marchan a la cabeza de la civilización capitalista, y en los primeros y no en los segundos es donde tiene mayor desarrollo la economía burguesa que ha de dar paso al socialismo.

¿Cómo habían de arraigar en la Rusia feudal, con unos campesinos acostumbrados a vivir en un régimen de esclavitud, las ideas socialistas igual que en la Inglaterra de más de un siglo de vida liberal y parlamentaria?» ${ }^{65}$.

El aire de identificación entre el laborismo británico y el socialismo español palpita insistentemente en la prensa adicta de los primeros meses de 1924. "La victoria de los trabajadores ingleses - se asevera de modo explícito- tiene que repercutir en España, aumentando las fuerzas del Partido Socialista, expresión política de los obreros españoles.»

La compenetración llega al terreno de la más elemental propaganda. Para «el día en que se abra de nuevo el Parlamento británico $\mathrm{y}$ en él se presente el primer Gobierno obrero inglés», se anuncian, por ejemplo, número especiales de El Socialista «con los 24 retratos de los principales colaboradores de Mac Donald» ${ }^{6}$.

Se muestra la conciencia de que, paradójicamente, el socialismo se ha trocado en defensor prioritario de la democracia individualista en Europa, por el fracaso de los liberales históri$\cos$ y por la iniciada pujanza de los movimientos autoritarios. "Con honda emoción» ${ }^{67}$ transcribe por eso El Socialista estas frases de The Daily Herald, órgano laborista:

En Alemania, las tendencias generales hacia un Gobierno reaccionario y hacia la esclavitud de las masas populares proceden de las mismas raíces envenenadas. En Italia y en España, los regímenes democráticos han sido derrocados por movimientos reaccionarios y los derechos del pueblo han desaparecido.

65 Ibidem, 26-I-1924.

66 Ibidem, 1-II-1924.

o7 Ibidem, 28-I-1924. 
$\mathrm{Y}$ es ello lo que da trascendencia mayor al triunfo electoral inglés:

"Un cambio se ha operado. Las vanguardias de todos los países han sentido que una brisa fresca y vivificante soplaba a través del árido desierto del despotismo.» Los sucesos del Reino Unido han venido a «infundir alientos a todos aquellos que están luchando por conquistar su libertad política y económica» ${ }^{68}$.

Sirve, pues, como símbolo, pero sirve además porque podría alzarse como el primer reducto en la defensa de la libertad frente a aquellos regímenes totalitarios.

Por eso insiste Fabra Ribas entonces - siempre el invierno del año $24-$ en que el éxito de la política exterior laborista interesa a «todos los liberales, los demócratas, los pacifistas y, en modo muy particular, los socialistas».

«Conviene tener esto muy en cuenta. Conviene, sobre todo, repetir, para que nadie las ignore y todo el mundo medite sobre su trascendencia», las palabras que H. N. Brailsford, uno de los delegados del Labour Party que asistió al Congreso de Marsella, dirigió a los compañeros franceses:

"Este no es -dijo Brailsford- un Gobierno extranjero, sino un Gobierno socialista"» ${ }^{69}$.

\subsection{Hacia LA POLITIZACróN DE LA U.G.T.}

El entusiasmo ante el éxito inglés no queda, sin embargo, en admiración, sino que, de inmediato, se convierte en proyecto de reorganización y reconversión del socialismo peninsular.

El primero en proponerlo en términos resonantes es Largo Caballero, en una conferencia pronunciada el 29 de febrero de 1924 en la Casa del Pueblo de Madrid:

Nosotros defendimos en dicha Conferencia -relataría él mismo más tarde- que el Partido Socialista y la Unión General debieran actuar conjuntamente en todo lo que políticamente les uniera, para lo cual debía darse forma orgánica a la labor que hasta hoy venían haciendo unidos por iniciativa de uno $u$ otro Comité, $y$ que para ello se

68 Cit., ibidem.

69 A. Fabra Ribas: La misión del Labour Party, ibidem, 12-1I-1924. 
nombrase un órgano mixto que dirigiese y encauzara esa acción común ${ }^{70}$.

Con mayor precisión, vuelve a exponer su criterio en $\mathrm{La} \mathrm{Li-}$ bertad, en marzo, en una entrevista con el periodista político Darío Pérez, siempre en torno a su disertación en la Casa del Pueblo ("que ha tenido resonancia, y que tendrá eficacia, por su influjo, en las organizaciones obreras, en la gran órbita de la política nacional»).

El líder socialista parte otra vez de una declaración de principios respecto a la organización del movimiento que dirige:

Existe, dice, de una parte la Unión General de Trabajadores, nacida con una finalidad eminentemente profesional, no doctrinal ni, por lo tanto, socialista. Porque, en su origen, «la Unión General es el instrumento de protesta contra el privilegio y de afirmación en un propósito de hacer accesible a la actividad de los obreros organizados todas las fuentes naturales y sociales de la producción».

En principio no es, insistimos, la vertiente sindical del socialismo, como se afirma habitualmente. No es cierto -afirma Largo Caballero de forma explícita- «que la Unión fuese el Partido Socialista ni en manos de éste estuviera aquélla», sino que "cada cual podía defender sus opiniones políticas aun estando dentro de la Unión General de Trabajadores» ${ }^{71}$.

Aun manteniendo siempre su independencia respecto al Partido Socialista Obrero Español, sólo en su último Congreso previo a la Dictadura -el de 1919- aprueba la. U.G.T. una declaración socialista al adscribirse a la «orientación revolucionaria de la lucha de clases» para "crear las fuerzas de emancipación integral de la clase obrera, asumiendo algún día la dirección de la producción, el transporte y la distribución en intercambio de la riqueza social» ${ }^{72}$.

Pero la declaración de tal fin impone un compromiso de actividad al que no se ajusta la organización actual de la Unión. $\mathrm{Y}$ es por eso por lo que se hace necesaria su restructuración en profundidad y la creación de aquel «Comité mixto, dirigido mancomunadamente por los organismos nacionales».

Largo subraya con cuidado que la separación permanece $\mathrm{y}$

70 Largo Caballero: Presente y futuro..., pág. 244.

71 Apud El Socialista, 27-III-1924, que reproduce la entrevista publicada por La Libertad.

72 Cit., ibidem. 
ha de permanecer: "Siendo dos cosas distintas el Partido Socialista y la Unión General de Trabajadores, están compenetrados como ramas de un mismo tronco.» $Y$ por ello tal Comité no habrá de entorpecer, "sino todo lo contrario, para la actuación independiente, en lo peculiar, y la estrecha unión, en lo común». En concreto sería el encargado «de señalar en todo momento las líneas de conducta para la lucha».

Pero esta lucha ya no permite dividir las atribuciones (la política para el P.S.O.E.; la reivindicación laboral para la U.G.T.); sino que, muy al contrario, exige potenciar la influencia también política de la Unión. «Los tiempos acentúan más la necesidad de proseguir esa evolución, porque no basta la acción económica para satisfacer las aspiraciones de los trabajadores.»

Incluso ya se puede concretar el primer campo de actuación. El 8 de marzo de 1924, el Directorio ha promulgado el Estatuto Municipal, que prevé la existencia de concejales de elección directa y de designación corporativa. $\mathrm{Y}$ esto hace previsible una consulta inmediata. Con criterio eminentemente pragmático, recuerda Largo Caballero que «el Estatuto impone sanciones a los organismos que tengan derecho en él reconocido y no se ejercite». Y prevé que los Comités Nacionales del Partido y la Unión tendrán que resolver «que mientras el Estatuto subsista habrán de ejercer aquellos derechos». Se hará preciso "llevar la intervención de la Unión General de Trabajadores al Municipio, al Parlamento, a la intervención tutelar de la vida pública».

Se hará preciso, por lo pronto, "por imposición de la ley», por el Estatuto en cuestión. Pero, «aun cuando no lo obligasen los derroteros que toma el Poder público, habría de hacerse desde el momento en que han desaparecido, desgraciadamente, las organizaciones republicanas», que de otra parte no parecen llevar camino de reconstituirse.

Largo Caballero sugiere con ello una sustitución del papel de convocatoria del republicanismo por el de las agrupaciones socialistas. El hecho de que no establezca en cambio la relación con liberales o demócratas monárquicos es sin duda importante: Largo no se atreve o no quiere afirmar una reconversión del socialismo en un laborismo estricto, dispuesto a ser poder en la monarquía.

Pero tampoco niega la posibilidad. Al referirse al Gobierno Mac Donald, lo pone como prueba: 
de que la evolución es un medio eficaz, de que la transformación social cabe lograrla sin trastornos y de que los socialistas, al informarse en este criterio, viven la realidad de las cosas. Para nosotros, lo ocurrido en Inglaterra es de una alta ejemplaridad, y ha hecho abrir los ojos a la ceguera de la intransigencia aceptando la eficacia del procedimiento.

En cuanto a la conquista del poder, elude el tema de la forma del régimen al terminar diciendo que la U.G.T. "precisa acentuar... [su] orientación en sentido político a las realidades que nos permita llevar nuestro influjo a todos los sectores de la gobernación nacional, mostrándonos capacitados para alcanzar en su día la realización de nuestros ideales dentro de la gobernación del país» ${ }^{73}$.

¿Hubo realmente una segunda intención en estas palabras y en aquel discurso de la Casa del Pueblo, con vistas a llegar a la sugerida reconversión del socialismo peninsular: no sólo en cauce de intervención política democrática de los trabajadores, sino incluso en partido de gobierno bajo la monarquía?

Maurín lo afirmaría taxativamente: la conferencia contenía el «proyecto de ir a la formación de un gran partido laborista» ${ }^{74}$.

En el mismo sentido, sin precisar, Antonio Amador se permite señalar en El Progreso de Barcelona, aun en marzo de 1924, la inclinación "hacia la derecha» de la Unión General en los últimos tiempos ${ }^{75}$.

En todo caso, la pretensión de Largo resulta verosímil, como un sagaz tanteo, si se pone en relación con otra manifestación inmediata, ahora de Fabra Ribas.

\subsection{Hacia la ampliación DEL P.S.O.E.}

Pocos días después de la conferencia de Largo, mediado ya el propio mes de marzo de 1924, pronuncia otra en la Casa del

\section{Ibidem:}

74 Joaquín Maurin: Los hombres de la dictadura. Sánchez Guerra. Cambó. Iglesias. Largo Caballero. Lerroux. Melquíades Alvarez, Madrid, Ed. Cénit, 1930, pág. 185. Vid., en el mismo sentido, Carr, op. cit., pág. 549, y, sobre todo, Gonzalo Redondo: Las empresas políticas de José Ortega y Gasset. "El Sol», "Crisol», "Luz» (1917-1934), tomo II, Madrid, Rialp, 1970, pág. $38 \mathrm{~s}$.

75 Lo reproduce El Socialista, 8-III-1924, y subraya su importancia Aunós: Política social..., pág. 49. 
Pueblo de Madrid, y en el mismo sentido que la de aquél, el socialista catalán Fabra Ribas.

Insiste en la temática de esos meses, que él mismo viene comentando en El Socialista: el movimiento obrero inglés y el gobierno del laborismo. En la segunda parte de su exposición, lo compara con la organización obrera y política de España. Su tesis, en principio, es aséptica:

En opinión del conferenciante, no puede decirse que la organización obrera inglesa es a la organización burguesa británica lo que la organización obrera española es a la organización burguesa española. No puede decirse, porque, por desgracia para todos, la burguesía española no está organizada, y la clase obrera sí.

Para, para probarlo, revista a las agrupaciones de unos y otros, $\mathrm{y}$ concluye en el punto básico:

Los espiritus mesiánicos pueden confiar en que han de surgir de un día a otro un partido o partidos liberales de la gran masa de ciudadanos pasivos, indiferentes e inéditos. Pero los hombres avisados, sin desconfiar de las posibilidades que nos reserva el porvenir, confían en lo que ya existe, tratando de fortalecerlo y ensancharlo.

Y lo que existe con verdadera fuerza es el P.S.O.E.

Hoy existe un fuerte Partido Socialista, una potente Unión General de Trabajadores, Cooperativas en el Norte, en Valencia, en Cataluña y en muchas localidades. Existen también numerosas Mutualidades.

Y viene a confluir en la propuesta práctica de Largo, implícitamente:

Lo que hay que hacer es potenciar lo que en común poseen todas esas sociaciones: "sin que sea necesario por eso que ninguna de ellas pierda la autonomía ni la independencia». "Dispuestos a trabajar en ese sentido, surgirán luego personalidades sueltas, Asociaciones independientes, núcleos de opinión que sólo esperan ser encauzados para poder actuar, que se unirían a este movimiento, convirtiendo así al movimiento obrero en el eje alrededor del cual se organizaría la vida social española.»

Se trata de aglutinar, evidentemente, no sólo a los socialistas 
estrictos, sino a todos los elementos demócratas de intenciones renovadoras. Y esto implica un también evidente peligro de deformación del Partido, que Fabra no termina de tolerar:

Mejor que surjan partidos verdaderamente liberales y democráticos», entre otras cosas, porque «es posible que con esta nueva táctica haya desprendimiento, mermas, siempre sensibles».

Pero lo ve como la alternativa idónea para que, en tanto no se integran esos verdaderos partidos, "la necesaria e indispensable función democrática no quede sin órgano apropiado para manifestarse».

Por lo demás, si hay mermas, "también habrá sumas, afluencias de nuevos adeptos, infusión de nuevas energías ${ }^{76}$.

Aunque a posteriori la relevancia histórica de la personalidad de Largo Caballero puede inducir a dar mayor significación a su conferencia que a la de Fabra Ribas, no parece que sucediera así en 1924. Y era lógico; porque es también probable que la personalidad de aquél no hubiera alcanzado aún la resonancia de éste.

La singladura de Antonio Fabra Ribas había sido rica ya en facetas sobresalientes, cuando no realmente originales.

Por una parte, sus años de residencia en Alemania, Gran Bretaña y Francia debieron contribuir de forma poderosa a su conocimiento de la organización socialista centroeuropea, precisamente en su versión socialdemócrata, laborista y revisionista. Colaborador con Jaurès en L'Humanité, sabía además, como escritor, presentar sus ideas con agudeza y capacidad de síntesis evidentes.

En España había destacado por una parte como uno de los principales esforzados en la difícil aventura de promocionar el socialismo en Cataluña. Pero esto le había inducido a buscar conexiones con los sindicalistas, que le permitieran construir el puente de ese trasiego. Por eso colabora con ellos en la relativa dirección de la Semana Trágica. Y por eso, paradójicamente, figura en 1910 entre los creadores de la Confederación Regional de Trabajadores del principado, que había de dar lugar a la C.N.T. La paradoja es más explicable en un socialista si se insiste en que, en su nacimiento, la Confederación Regional y la 
Nacional no son asociaciones anarcosindicalistas, sino sindicalistas revolucionarias.

Ninguna de estas actividades, por lo demás, le había apartado del P.S.O.E. ${ }^{\text {T }}$.

Sin duda por esa significación de Fabra y por el mayor alcance de su proyecto prolaborista de marzo de 1924, es él quien entonces suscita los mayores recelos, que dan lugar a la primera exteriorización destacable del cisma que se esboza en el socialismo español.

La réplica procede - también por lógica- de Indalecio Prieto.

En su artículo Un voto en contra, publicado en El Socialista el 26, de forma expresa Prieto se refiere a la disertación del publicista catalán y, en concreto, a «la segunda parte de su discurso, en la que, después de parangonar las organizaciones obreras que en la Gran Bretaña constituyen el bloque laborista con las de carácter político, sindical y cooperativo en que se agrupan los trabajadores españoles, aconseja una fusión semejante en pos de fines análogos a los rectores de la conducta laborista en Inglaterra».

Prieto rechaza, primero, aquella semejanza: porque difiere la «historia de la eficacia de la Constitución en Inglaterra y en España» y porque el cooperativismo español es con frecuencia "de origen y significación patronal» si no amarillo.

Pero en todo caso repudia la conveniencia de la fusión de grupos que Fabra propone:

En España hay dos fuerzas obreras positivamente sólidas: una, política, el Partido Socialista, y otra, sindical, la Unión General de Trabajadores. Fuera de ellas, nada o casi nada.

Acaso eludiendo o sin ver el alcance potencial de la propuesta de Largo a favor de la creación de un órgano mixto, la acepta:

Es plena nuestra conformidad con el pensamiento de Largo Caballero de intensificar el carácter político de la Unión General, incluso haciéndola netamente socialista.

77 Vid., sobre todo ello, el testimonio del propio Fabra Ribas: La Semana Trágica. El caso Maura. El krausismo, Seminarios y Ediciones, Madrid, 1975, 224 págs. 
(La frase es sumamente significativa para entender de nuevo el carácter de la U.G.T. en lo que atañe a su contenido doctrinal y a sus finalidades.)

... pero es absoluto nuestro disentimiento en cuanto a la amalgama aconsejada por Fabra Ribas.

En concreto, de sus teorías "pudiera desprenderse el [equívoco] de que con los núcleos socialistas y las fuerzas a ellos agregables se aspiraba a constituir en España lo que en lenguaje parlamentario se ha dado en llamar "la oposición de S. M."».

$Y$ el mal se agranda considerablemente si se pretende dar la impresión de que los elementos socialistas españoles, con ciertas agregaciones y suplementos, podrían constituir una fuerza gubernamental aprovechable, sin previas $y$ sustanciales mudanzas, en el presente régimen.

En otras palabras: lo que Fabra ha propuesto puede entenderse ciertamente como gubernamentalización del P.S.O.E. bajo la monarquía (si no bajo la Dictadura), al modo exacto del laborismo británico. $\mathrm{Y}$ es esto justamente lo que Prieto no acepta.

Mas Donald puede fiar no sólo en la conducta de los ministros, sino en la lealtad de todos a la Constitución jurada y en la elevada educación política del pueblo inglés para salir de la aventura, cuando no triunfador, por lo menos sin quebranto moral.

Y tales circunstancias no se dan en España.

Cuando el comunismo de Rusia -concluye- comenzó a deslumbrar con sus reflejos en el campo socialista español, nos apresuramos a reaccionar contra el insensato prurito de imitarlo. España no es Rusia, dijimos entonces. Pero tampoco es Inglaterra, decimos ahora ${ }^{78}$.

Es interesante observar el emplazamiento de las propias fuerzas que este escrito propone; emplazamiento que difiere del que pretende Largo, en distinción que va a ser fundamental en el cisma del socialismo hispánico.

78 Apud El Socialista, 26-III-1924. 
Prieto se empeña en situar el P.S.O.E. entre el comunismo y la democracia burguesa, a la que vendría por tanto a ser proclive el laborismo de Fabra Ribas. "Nuestras fuerzas - dice con precisión- no tienen por qué actuar de partido liberal ni de partido demócrata, sino sencilla y simplemente de Partido Socialistas ${ }^{79}$. De algún modo podría decirse que Prieto quiere encarnar así la izquierda socialista frente al derechismo de aquél.

Pero este no es tampoco el planteamiento de Largo. En la medida en que la disyuntiva vaya desenvolviéndose en argumentos, veremos cómo Fabra desaparece de la primera plana de la polémica interior y aquél, en cambio, viene a insistir en la primacía ugetista sobre el Partido. En otros términos: el laborismo de Largo Caballero se va a trocar en una tercera línea, no en medio sino al margen o incluso a la izquierda del purismo de Prieto y del colaboracionismo de Fabra Ribas.

Por lo demás, el propio Fabra Ribas se apresura a rectificar a Indalecio Prieto el 28 de marzo de 1924, pero en el sentido de quitar importancia al tema del gubernamentismo. «Nosotros intentamos simplemente exponer un método, la forma de desarrollo de un proceso evolutivo, indicando que la celeridad en la marcha constituye un problema puramente adjetivo, mientras que lo verdaderamente importante es escoger bien el camino que se va a seguir» ${ }^{\infty}$. Fabra - dirá después El Socialista- «no ha defendido, pública ni privadamente, la participación ministerial con la Monarquía española» ${ }^{81}$.

En verdad, la respuesta del militante catalán no sacaba de dudas.

$\mathrm{Y}$, de otra parte, la propia duda comenzaba a ganar los medios políticos: no sólo en relación con la evidente discordancia entre el socialista catalán e Indalecio Prieto, sino con la mucho más matizada —e incluso negada - de Prieto y Largo Caballero. Así, a finales de marzo, El Progreso se refería en Barcelona al enfrentamiento de los dos últimos, por el intento del segundo de fundir por completo el P.S.O.E. y la U.G.T. por medio de aquel Comité mixto. «Largo Caballero es favorable a una alianza socialista-republicana», afirmaba además, ciertamente mal orientado, el periódico lerrouxista ${ }^{82}$.

$\mathrm{Y}$ por las mismas fechas se comenzaba a criticar abiertamen-

79 Ibidem.

80 Ibidem, 28-III-1924.

81 Ibidem, 8-IV-1924.

82 Cit. ibidem, 2-IV-1924. 
te también la gestión de Llaneza, «equivocada y perniciosa» según el escritor catalán Gabriel Alomar ${ }^{23}$.

\section{La frustración del laborismo}

No hay duda de que, en principio, el criterio seguido por las organizaciones socialistas como tales no se comprometió -ni podía llevarlo a cabo - con ninguna de las tres opciones: ni con la politización de la U.G.T., ni con la ampliación del socialismo en sentido liberal y gubernamental, ni con su mantenimiento en la línea purista. Pero es cierto también que decisiones inmediatas apuntaron con claridad y oportunismo hacia la puesta en práctica de las reivindicaciones más concretas de cuantas formulara Largo Caballero en su conferencia: en pro de la primera de aquellas tres opciones por tanto.

\subsection{LA RECONSTITUCIÓN DE LOS MUNICIPIOS}

A tal fin, el 31 de marzo de 1924, en la segunda sesión del Pleno de los Comités Nacionales de la Unión General y el P.S.O.E. (una de aquellas reuniones conjuntas pero circunstanciales a que Largo aludiera), se adopta una resolución sobre el comportamiento de ambos grupos ante las hipotéticas elecciones que pudiera implicar la reciente promulgación del Estatuto Municipal por el Directorio. En la correspondiente nota oficiosa, los Comités consideran «improcedente» el sistema electoral contenido en él y piden su reforma. Pero en tanto se logre, "y siendo obligatorio el ejercicio de la representación corporativa en los Municipios», ordenan que las asociaciones adheridas a la U.G.T. y al Partido se inscriban en el censo y designen a los concejales.

$\mathrm{Y}$, sobre todo, conforme a la propuesta de Largo, «para organizar y dirigir todo lo relacionado con el nombramiento y actuación de los representantes... en los Municipios», disponen la creación de «un Comité mixto, compuesto de seis individuos, tres

83 Gabriel Alomar: El Socialismo español en su prueba histórica, reproducido ibidem, 8-IV-1924. 
de cada una [de las dos organizaciones socialistas], que tendrá en los asuntos de su competencia las mismas atribuciones y responsabilidades que los Comités Nacionales nombrados por el Congreso".

De momento, con ello, inicia su existencia el organismo sugerido en aquella disertación de la Casa del Pueblo, aunque su actividad se limita en principio a las supuestas elecciones.

El acuerdo ha sido adoptado en este sentido "por unanimidad», pero no en presencia de Prieto, que había excusado su asistencia al Pleno por carta. Los Comités se curan en salud por lo demás añadiendo que todo lo antedicho habría de ser sometido, punto por punto, «a la aprobación de las Secciones de los organismos nacionales para que ellas resuelvan, a ser posible, por medio del referéndum». Se entiende, evidentemente, el delicado carácter de la decisión, en definitiva dispuesta a la actuación electoral exigida por ley y no a la oposición abierta frente a ella.

Por otra parte, como hemos visto, se ha planteado ya la posibilidad de los nombramientos digitales de ediles, y como el Estatuto contempla las dos posibilidades (designación de concejales por las autoridades y por elección corporativa), los Comités insisten en el criterio adoptado el 9 de enero tras el caso Botana: deciden otra vez "por unanimidad que sólo se acepten los cargos de concejales en las condiciones ya acordadas anteriormente por el Pleno del Comité Nacional del Partido Socialista, es decir, cuando las autoridades se dirijan oficialmente a las organizaciones y éstas, con plena libertad, designen a sus representantes, como lo han hecho hasta ahora para toda clase de organismos» ${ }^{84}$.

La insistencia no había de resultar ociosa. El 2 de abril de 1924, Largo Caballero, Manuel Cordero, Eduardo Alvarez y Andrés Saborit recibían el nombramiento de concejales para el ayuntamiento de Madrid y lo rechazaban por haber sido realizado por el gobernador civil «sin la intervención de las Sociedades obreras madrileñas».

Estos cargos -indicaba una vez más El Socialista- se pueden aceptar si las autoridades se dirigen oficialmente a

84 Apud El Socialista, 1-IV-1924, o Partido Socialista Obrero Español. Convocatoria y orden del día para el XII Congreso..., pág. 99. 
la organización, y ella, por los procedimientos democráticos usuales en nosotros, elige libremente a sus representantes ${ }^{85}$.

En el mismo sentido y por motivo idéntico se dan renuncias de «concejales corporativos», nombrados tales en la realidad por los respectivos gobernadores civiles, en diversos puntos de España: así Vicente Navarro y José María Juan Comes en Valencia, Vallejo en Córdoba, Rafael Mira y Manuel Acero en Baeza ${ }^{86}$, Jaime Comes To en Mataró ${ }^{87}$, y otros socialistas de Alicante, Almansa, Barcarrota, Barruelo, Caborana, Cádiz, Elche, El Ferrol, Erandio, Gallarta, Oviedo, Palencia, Puentegenil, Puertollano, Salamanca, Tarazona de la Mancha y Valladolid ${ }^{88}$.

Se dan, por otra parte, actitudes heterodoxas en relación con lo dispuesto por los Comités Nacionales, aunque estas excepciones no hacen a la larga sino ratificar la claridad de la actuación de éstos. El asunto mejor sabido - porque fue de inmediato público- es le de Juan Salas Antón.

Siempre en la segunda quincena de marzo de 1924, el gobierno civil de Barcelona había ofrecido sendas concejalías a dos miembros del P.S.O.E., que consultaron la aceptación al Comité de la Agrupación Socialista de Barcelona.

La respuesta fue negativa para ambos casos, en razón del proceso no democrático del nombramiento. $\mathrm{Y}$, consultado por la propia Agrupación catalana, el Comité Nacional se pronunció en el mismo sentido.

Ambos, en consecuencia, renunciaron. Pero, a pesar de esto, Salas -uno de ellos - fue designado formalmente no a título socialista; sino como representante del movimiento cooperativo en que actuaba.

A instancias de una comisión enviada al efecto por la citada Agrupación, el nuevo concejal decidió aceptar el cargo, presionado según parece por «numerosos elementos cooperadores», en razón del bien que podía hacerse con ello «a aquellas organizaciones y a sus generosos ideales». Así lo expuso por escrito,

\footnotetext{
85 El Socialista, 2-IV-1924.

\$6 Cf. ibidem, 8-IV-1924.

87 Cf. ibidem, 2-IV-1924.

88 Cf. Partido Socialista Obrero Español. Convocatoria y orden del dia para el XII Congreso..., pág. 365.
} 
en el que comprendía además la consiguiente separación del P.S.O.E. que habría de imponérsele:

«... en el caso, para mí muy doloroso, en que hubiese de separarme del Partido para librarle de toda responsabilidad en mi decisión, no dejaré, sin embargo, de seguir siendo socialista con el mayor entusiasmo y dispuesto a servir a ustedes y a nuestros comunes ideales en todos los terrenos ${ }^{89}$.

Salas Antón fue cordial pero inmediatamente cesado en efecto en la organización socialista barcelonesa ${ }^{90}$.

Una expulsión semejante, por los mismos motivos, se dio en León ${ }^{91}$.

Junto a aquellos nombramientos rechazados y junto a éstos aceptados contra las normas de los Comités Nacionales, quedan en fin los llevados a cabo conforme a tales reglas, por elección de las agrupaciones socialistas.

Naturalmente, también en esta designación ortodoxa de los corporativos se dan casos peculiares, que invitan a la renuncia, y situaciones paradójicas.

Entre los primeros destaca la renuncia de tales sociedades al puesto de concejal que se les ofrece en Zaragoza, movidas por "circunstancias especiales»"2.

Entre las segundas se dan sorprendentes cambios de estatuto jurídico en una misma persona, al socaire de los propios cambios de normativa.

Así, en Mora de Toledo, el socialista Eladio Romeral Iglesias figura como concejal de elección popular antes del golpe de Estado. Es destituido el primero de octubre de 1923 como todos los ayuntamientos del país. Vuelve a ser designado el 12 de febrero de 1924, para ser destituido tres semanas después "por su gestión», con todo el ayuntamiento. A él regresa más tarde como concejal corporativo, hasta que, siendo teniente de alcalde, «se negó a asistir a una fiesta religiosa» y fue otra vez cesado. Nuevamente elegido como corporativo, como tal permanece al menos cuando acaba el año $1927^{93}$.

89 Apud El Socialista, 2-IV-1924.

90 Cf. ibidem.

91 Cf. Partido Socialista Obrero Español. Convocatoria y orden del dia para el XII Congreso..., pág. 366.

92 El Socialista, 17-VIII-1929.

93 Partido Socialista Obrero Español. Convocatoria y orden del día para el XII Congreso..., pág. 367. 
En conjunto, hasta el fin de este año, «han tenido concejales corporativos, de acuerdo con las prescripciones del Partido y de la Unión General, en las siguientes localidades, cesando por diferentes motivos:

\begin{tabular}{|c|c|c|}
\hline Alhaurin el Grande ... ... & 1 & Suma anterior ... ... \\
\hline 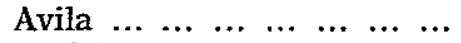 & 2 & \\
\hline $\begin{array}{ccccccc}\text { Badajoz } & \ldots & \ldots & \ldots & \ldots & \ldots & \ldots\end{array}$ & 2 & Málaga ....... \\
\hline $\begin{array}{lllllll}\text { Burgos } & \ldots & \ldots & \ldots & \ldots & \ldots & \ldots\end{array}$ & 1 & Mataró $\ldots \ldots \ldots \ldots \ldots \ldots$ \\
\hline $\begin{array}{cccccc}\text { Caborana } & \ldots & \ldots & \ldots & \ldots & \ldots\end{array}$ & 1 & $\begin{array}{llllllll}\text { Mora } & \ldots & \ldots & \ldots & \ldots & \ldots & \ldots & \ldots\end{array}$ \\
\hline $\begin{array}{lllllll}\text { Cáceres } & \ldots & \ldots & \ldots & \ldots & \ldots & \ldots\end{array}$ & 1 & Pego $\ldots \ldots \ldots \ldots$ \\
\hline Callosa de Segura $\ldots \ldots \ldots$ & 1 & 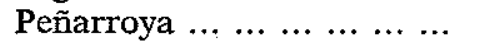 \\
\hline Campo de Criptana $\ldots \ldots$ & 1 & $\begin{array}{lllllll}\text { Petrel } & \ldots & \ldots & \ldots & \ldots & \ldots & \ldots\end{array}$ \\
\hline Carabanchel Bajo $\ldots . . . .$. & 1 & $\begin{array}{lllllll}\text { Pozoblanco } & \ldots & \ldots & \ldots & \ldots & \ldots\end{array}$ \\
\hline Casasola de Arión $\ldots \ldots \ldots$ & 1 & Puenteáreas $\ldots . \ldots \ldots \ldots$ \\
\hline Chamartín de la Rosa ... .... & 1 & Sama de Langreo $\ldots \ldots \ldots$ \\
\hline $\begin{array}{ccccccc}\text { Gallarta } & \ldots & \ldots & \ldots & \ldots & \ldots & \ldots\end{array}$ & 1 & $\begin{array}{llllll}\text { Sitges } & \ldots & \ldots & \ldots & \ldots & \ldots\end{array}$ \\
\hline $\begin{array}{lllllll}\text { Gerona } & \ldots & \ldots & \ldots & \ldots & \ldots & \ldots\end{array}$ & 1 & $\begin{array}{llllll}\text { Valdepeñas } & \ldots & \ldots & \ldots & \ldots & \ldots\end{array}$ \\
\hline $\begin{array}{cllllll}\text { Lagartera } & \ldots & \ldots & \ldots & \ldots & \ldots & \ldots\end{array}$ & 1 & $\begin{array}{llllllllllll}\text { Villacarrillo } & \ldots & \ldots & \ldots & \ldots & \ldots\end{array}$ \\
\hline $\begin{array}{lllllllll}\text { La Seca } & \ldots & \ldots & \ldots & \ldots & \ldots & \ldots\end{array}$ & 1 & $\begin{array}{llllllllllll} & \ldots & \ldots & \ldots & \ldots & \ldots & \ldots & \ldots & \ldots\end{array}$ \\
\hline
\end{tabular}

En cambio, asimismo, al final de 1927, tienen concejales socialistas en sus ayuntamientos, sea cual fuere el origen de su elección ("por haber sido elegidos directamente por la organización obrera o por haber pertenecido a las Juntas de asociados»), los siguientes lugares:

\begin{tabular}{|c|c|}
\hline $\begin{array}{llllllll}\text { Avilés } & \ldots & \ldots & \ldots & \ldots & \ldots & \ldots & \ldots\end{array}$ & 2 \\
\hline $\begin{array}{ccccccc}\operatorname{Badajoz} & \ldots & \ldots & \ldots & \ldots & \ldots & \ldots\end{array}$ & 2 \\
\hline $\begin{array}{llllllll} & \text { Bélmez } & \ldots & \ldots & \ldots & \ldots & \ldots & \ldots\end{array}$ & 5 \\
\hline $\begin{array}{lllllll}\text { Burggos } & \ldots & \ldots & \ldots & \ldots & \ldots & \ldots\end{array}$ & 1 \\
\hline $\begin{array}{llllll}\text { Crevillente } & \ldots & \ldots & \ldots & \ldots & \ldots\end{array}$ & 2 \\
\hline $\begin{array}{llllll}\text { Cabañaquinta } & \ldots & \ldots & \ldots & \ldots\end{array}$ & 1 \\
\hline $\begin{array}{lllllll}\text { Cáceres } & \ldots & \ldots & \ldots & \ldots & \ldots & \ldots\end{array}$ & 1 \\
\hline Campo de Criptana $\ldots . .$. & 1 \\
\hline Casasola de Arión $\ldots \ldots \ldots$ & 1 \\
\hline $\begin{array}{lllllll}\text { Lagartera } & \ldots & \ldots & \ldots & \ldots & \ldots & \ldots\end{array}$ & 1 \\
\hline
\end{tabular}

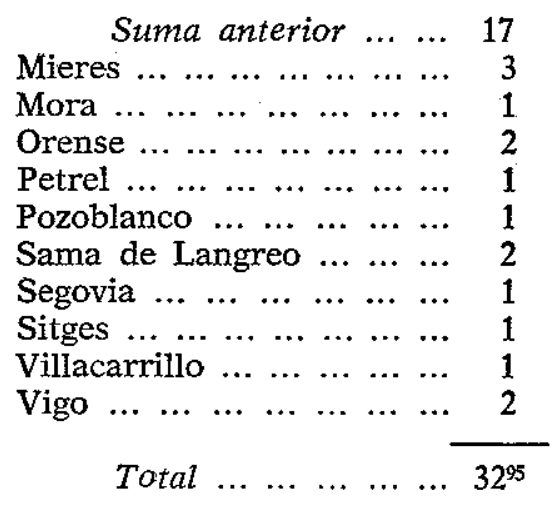

94 Ibidem, pág. 365.

95 Ibidem, pág. 366. En ninguna de estas series aparece Benavente, 
El resumen interesado de Aunós, «en algunos pueblos los socialistas renunciaron a sus nombramientos de concejales corporativos, pero en la mayoría los aceptaron, prometiendo una sincera colaboración» (sic) ${ }^{96}$.

De hecho, esta participación en los ayuntamientos, heterodoxa o no, ahondó evidentemente la acusación de colaboracionismo y el recelo en las propias filas socialistas. Por eso ante la amenaza de una protesta pública de medios comunistas contra los acuerdos de los Comités Nacionales del P.S.O.E. y la U.G.T. acerca del Estatuto Municipal, El Socialista insiste de forma significativa en la conveniencia de explicar bien los acuerdos de la Unión y del Partido" para evitar cualquier perturbación "en el seno de las organizaciones»" ${ }^{97}$. Las normas son muy claras y Sobran las consultas - titula un suelto el mismo diario en abril ${ }^{98}$.

\subsection{SistematiZACióN DEL ACERCAMIENTo}

No debe de pensarse que los afanes de conversión del socialismo español en laborismo se reducen a la participación en los ayuntamientos ni a la creación del Comité mixto propuesto por Largo Caballero, y esto, con vistas sólo a las supuestas elecciones municipales. Por el contrario, en marzo y en abril de 1924, las excitaciones en pro de una renovación más ambiciosa prosiguen.

Incluso la constitución del Comité se troca en acicate para ellas en la pluma de Araquistáin:

Pocos sucesos exteriores -escribía en El Sol el 30 de marzo de 1924- están destinados, por lo visto, a ejercer en España una influencia tan profunda como el advenimiento del laborismo británico al Poder. ... hombres como Largo Caballero y Fabra Ribas, en conferencias y declaraciones

donde El Socialista, 2-IV-1924, da a entender sin embargo que hubo designación de concejal o concejales por parte de las agrupaciones socialistas.

\% Aunós: Política social..., pág. 50.

9 El Socialista, 8-IV-1924.

98 Ibidem. 
recientes, [se han sentido movidos] a recoger las enseñanzas del victorioso laborismo inglés, y a modificar la estructura del equivalente español. El fenómeno trasciende, por sus posibilidades históricas, de los estrictos límites de una clase y adquiere dimensiones nacionales.

La revolución rusa de 1917 -explica一 hizo pensar al socialismo español en la posibilidad del triunfo inmediato por vía de la violencia y la oposición ilegal. Y en tal camino hay que entender la intentona de la huelga general del verano del mismo año. «... pero la audacia de unos quedó neutralizada por la prudencia de otros», y el paro fracasó en su propósito revolucionario.

Luego, con todo, el mantenimiento del Gobierno soviético en el poder hizo pensar en su accesibilidad. Y, ahora, "la exaltación del laborismo inglés al Gobierno ha completado el proceso psicológico, con la evidencia de que un Gabinete socialista es allí una espléndida realidad». «El momento y la ocasión no se ven aún..., pero la fatalidad de que sobrevengan parece ya evidente.»

$\mathrm{Y}$ aquí se inscriben las nuevas iniciativas teóricas y prácticas:

Esta noción de su destino nacional, como gobernantes inevitables, explica el nuevo giro que tratan de imprimir a las organizaciones que hasta ahora eran puramente gremiales, como las que integran la Unión General de Trabajadores...

De ahí esa curiosa tentativa de vincular la Unión General de Trabajadores y el Partido Socialista mediante un Comité común, sin fundirlos, respetando su peculiar autonomía, como hace el Partido laborista inglés con sus organizaciones integrantes.

Como en el Reino Unido, «una estrecha alianza teórica y táctica del Partido Socialista y la Unión General de Trabajadores puede producir grandes sorpresas electorales en el futuro régimen de representación municipal y nacional».

Por eso, y por el derrumbe «de todos los otros partidos políticos», el Socialista "puede llegar a ser, en cualquier momento de confusión caótica, nada imposible, una garantía de continui- 
dad histórica y coherencia social, o sea, una fuerza nacionalmente conservadoras ${ }^{99}$.

En sueltos posteriores, a lo largo de abril en particular, El Sol y Araquistáin continúan jaleando el nuevo planteamiento ${ }^{100}$.

Algo parejo se halla en los escritos coetáneos del catalán Gabriel Alomar:

También para él «el Socialismo español ha llegado a un momento histórico de prueba»; asimismo porque ya no puede ceñirse «a sus vindicaciones de clase y a su causa de emancipación universal», sino que se ha imbuido en "la vaga y creciente convicción de ser un reducto en que se han refugiado las instintivas esperanzas españolas». En tales esperanzas por supuesto se incluye la de, en su día, «aceptar la carga de un Gobierno de transición, sacrificando momentáneamente la doctrina pura de justicia social a la restauración de la libertad política» (se supone, por el contexto, que en una transición que conduzca no sólo de la dictadura a la democracia, sino además a la república).

Pero Alomar alude al impacto de «la subida del laborismo inglés al Gobierno (que no al Poder)» para alinearse expresamente junto a Indalecio Prieto y contra Fabra Ribas:

El experimento del laborismo inglés (que no es el Socialismo) no tiene nada que ver con la hipotética misión reconstructora y gubernativa del Socialismo en España. Sin que ahora queramos dar a la palabra Revolución ningún sentido catastrófico, es innegable que aquella supuesta función de nuestro socialismo debería ser revolucionaria, y que anejas a ella, ineludiblemente, irían ciertas cuestiones previas que para ninguna conciencia verdaderamente liberal pueden ser ya dudosas. De modo que la capacitación de gobierno, o la ductilidad de ideario, o la sutileza de los distintos moderadores no pueden pasar de ciertos límites.

«El Socialismo —sentencia, con Prieto-, como núcleo de renacimiento liberal y democrático, no puede ser un "sucesor" de nadie» ${ }^{10 t}$.

99 Reproducido ibidem, 1-IV-1924.

100 Vid. Redondo: op. cit., II, $38 \mathrm{~s}$.

101 Gabriel Alomar: El Socialismo español en su prueba histórica, La Libertad, reproducido por El Socialista, 8-IV-1924. 
Lo que en la primavera de 1924 pretende imponerse estriba, según vemos, en un complejo de inquietudes renovadoras más que en una actitud única y definida. Se palpa el hecho de que la crisis del turnismo y la incapacidad de los republicanos para lograr el cambio de régimen han situado al socialismo en un papel histórico de alcance inesperado. En 1924 tiene visos de ser, ciertamente, la fuerza más y mejor trabada en la política peninsular.

Y esto a unos exhorta a persistir en una línea al tiempo democrática y socialista, en equilibrio riguroso de ambos extremos: sin alianza posible con la autocracia militar, ni con la monarquía siquiera, ni tampoco confusión con el liberalismo histórico.

A otros inclina hacia la primera vertiente: en pro de la ampliación de su fuerza mediante la asimilación de todos los demócratas, socialistas o no, a fin de terminar la conversión del P.S.O.E. en esa base nacionalmente conservadora de que habla Araquistáin.

$\mathrm{Y}$, en fin, lleva a otros aún a potenciar al máximo en política la carga obrera de la organización -en este caso, claro está, la U.G.T.-: como otra forma de conseguir la misma pretensión de conducir a pleno rendimiento la marcha del movimiento socialista.

Prieto, Fabra Ribas y Largo Caballero encabezan las tres posturas, en principio difusas, pero paulatinamente definidas, por obra de la propia polémica que suscitan.

Por lo demás, esa polémica, que ayuda a perfilar los distintos criterios, no sólo lo consigue para diferenciarlos entre sí, sino también para marcar su alcance. En otras palabras: el recurso inicial al término laborismo como punto de referencia, cuando no como meta, va cediendo ante otras fórmulas verbales en la medida en que se manifiestan los temores de que el énfasis liberal de Fabra o el ugetista de Largo Caballero conduzcan a un gubernamentalismo monárquico. Y cede, de otra parte, también en la medida en que se confunden con él actitudes distintas: bien sean inconcretos afanes de evolución política con el respaldo socialista (como podría verse en Araquistáin), o iniciativas de origen sindical, no menos imprecisas.

En este último campo habría que situar la noticia, una vez más en la segunda quincena de marzo de 1924, del proyecto de 
constituir «un titulado partido laborista, a la cabeza de cuya supuesta agrupación figuraría el señor Barriobero»: sin duda, Eduardo Barriobero, republicano federal proclive al anarquismo, de hecho asesor jurídico de la C.N.T.

No es difícil comprender que los socialistas históricos comenzaran a recelar del nombre y del socialismo de «quienes para no serlo inventan eso del laborismo, que ya fracasó varias veces y fracasará ahora también, si es que los rumores se llegaran a confirmar».

En cierto modo; pues, la propia iniciativa ayuda a definir con claridad las posturas:

Lo único organizado en el proletariado de nuestro país es la Unión General y el Partido Socialista, y quienes deseen acelerar el advenimiento de un régimen de mayor justicia y bienestar social tienen el deber de ingresar en sus filas; pero no para falsear las ideas de esos organismos, sino para servirlas abnegadamente ${ }^{102}$.

\subsection{La vocalía del Consejo de Estado}

En principio, durante los meses siguientes de 1924, nada parece añadirse en el orden práctico que haga pensar efectivamente en una transformación en el P.S.O.E. o en la U.G.T. La participación en las corporaciones oficiales prosigue. Pero continúa también ciñéndose a las normas preestablecidas, que dan a esa presencia de los socialistas en los cargos públicos una marcada nota profesional y aséptica.

Así, el 19 de junio de 1924 un real decreto constituye el Tribunal Supremo de la Hacienda Pública, cuyo reglamento especifica que el Consejo Interventor de Cuentas del Estado podrá contar con representantes de las agrupaciones obreras, por ellas elegidos. En previsión de que esta posibilidad se realice, la Comisión Ejecutiva de la U.G.T. se dirige a todas sus secciones para aconsejarles la participación y en concreto la votación por la candidatura de Wenceslao Carrillo y Manuel Cordero para vocales efectivos y Francisco Núñez Tomás para la vocalía suplente.

Verificadas las elecciones, participan en ellas 443 secciones

102 Ibidem, 5-IV-1924. 
de la Unión General; "pero, sin que se conozcan las causas, la elección fue anulada por el Consejo Interventor de Cuentas del Estado. La Ejecutiva [de la U.G.T.] presentó la correspondiente protesta ante el Consejo y el señor ministro de Hacienda, sin que diera resultado».

Convocadas de nuevo; «la Comisión Ejecutiva insistió cerca de las Secciones para que votasen la misma candidatura» y triunfaron ${ }^{103}$.

Al tiempo, entre abril y junio de 1924, el Directorio crea el Consejo Superior de Trabajo y suprime el Instituto de Reformas Sociales. Aunque en principio esta segunda medida fue interpretada como "una maniobra contra la Unión General» ${ }^{104}$, de hecho los vocales obreros que figuraban en el Consejo de Dirección del Instituto de Reformas Sociales (Largo Caballero, Núñez Tomás, Lucio Martínez y Santiago Pérez Infante) quedan incorporados interinamente por real orden al nuevo Consejo Superior de Trabajo.

Reunidos en Madrid, los interesados deciden aceptar la incorporación, y la Comisión Ejecutiva y el Comité Nacional de la U.G.T. ratifican su decisión ${ }^{105}$. No es extraña ni baladí esta intervención de los dos organismos rectores de la U.G.T. En rigor, lo que hasta entonces se había autorizado era el mantenimiento en los puestos oficiales cubiertos con anterioridad al golpe de Estado y el acceso a los de nueva provisión, con tal de que, en ambos casos, se tratara de cargos representativos, en los que no mediase una designación realizada por el poder civil. En verdad, esto era justamente lo que no sucedía con el nombramiento de los vocales interinos para el Consejo Superior de Trabajo, llevado a cabo por real orden directamente, sin previa elección ni designación por parte de la U.G.T., aunque recayera en personas nombradas del modo ortodoxo para un organismo del que en cierta medida era prolongación el nuevo Consejo.

Se trataba, por tanto, de una situación discutible, según se aplicara la letra o el espíritu de las condiciones establecidas por el poder ejecutivo de la Unión General. De ahí que este mismo poder (detentado por aquella Comisión Ejecutiva y por

103 Unión General de Trabajadores. Convocatoria y orden del día del XVI Congreso..., pág. 11.

104 Saborit: Julián Besteiro, pág. 167.

105 Cf. Unión General de Trabajadores. Convocatoria y orden del día del XVI Congreso..., pág. 11. 
el Comité Nacional) hubiera de sancionar el acuerdo de los vocales.

La cuestión era tanto más delicada cuanto podía incidir en la división de los socialistas, surgida precisamente de la cuestión de los cargos.

Es interesante saber, para completar el cuadro, que en estos mismos días, y con la misma discreción que ante la entrevista de Llaneza y el dictador en octubre, Pablo Iglesias esboza su propia postura. El 29 de julio de 1924 firma un comentario en El Socialista, «Habrá Parlamento», sobre los proyectos de institucionalización de la Dictadura. Y La Epoca lo interpreta el 31 como «un indicio más de la actitud gubernamental en que se halla colocado el Partido obrero» ${ }^{106}$. Iglesias muere al año siguiente.

Hasta aquí, insisto, la participación no implica innovación respecto a la actitud perfilada en el invierno de 1923-1924, antes de la campaña prolaborista. En el otoño del 24, sin embargo, va a realizarse un conjunto complejo de situaciones que por lo menos son susceptibles de una interpretación en el mismo sentido: como una disposición efectiva a colaborar con la monarquía. Y ello terminará de ahondar la escisión en el seno del P.S.O.E.

Se trata de un momento que es preciso analizar con detalle, más si se toman en consideración las divergencias entre las distintas versiones» ${ }^{107}$.

Por real decreto de 13 de septiembre de 1924 (primer aniversario del pronunciamiento), el Directorio reforma el Consejo de Estado creando varias vocalías nuevas para dar entrada a representantes de diversos órganos oficiales, entre otros -uno

106 Cit. Aunós: Política social..., pág. 50. guiente.

107 En principio, no voy a pormenorizar esas divergencias salvo en los casos indispensables. Adelanto que lo que sigue está basado en Partido Socialista Obrero Español. Convocatoria y orden del día para el XII Congreso..., págs. 103 s.; XII Congreso..., págs. 151 ss.; Unión General de Trabajadores. Convocatoria y orden del día del XVI Congreso...; Saborit: Julián Besteiro, pág. 167; Largo Caballero: Pasado y futuro..., pág. 44 y ss.; Idem: Mis recuerdos..., págs. 92 ss.; Aunós: Politica social..., páginas 51 ss.; Redondo: op. cit., II, pág. 43. Es particularmente la relación de Aunós. 
más- el Consejo Superior de Trabajo. Se le atribuye a éste en concreto una vocalía obrera y otra patronal, ambas a designar por el presidente del propio Consejo de Trabajo.

De acuerdo con lo dicho, la vocalía obrera resulta inaceptable para los socialistas por el procedimiento de designación que establece el decreto, que le quita todo carácter representativo.

Pero los propios socialistas van a buscar un modo de ocupar este nuevo cargo, con un criterio semejante al empleado en la cuestión del Instituto de Reformas Sociales. Pretenderán imponer el espíritu representativista de las condiciones establecidas por la U.G.T. para estos casos, aunque no sea posible sujetarse a la letra.

La manera de hacerlo fue tratada en fecha imprecisa por la Comisión Ejecutiva de la Unión General, que entonces «por unanimidad acordó que los vocales obreros en el Consejo de Trabajo aceptaran el puesto e hicieran la oportuna propuesta ${ }^{108}$. $\mathrm{Y}$, en efecto, reunido el 22 de septiembre de 1924 el Consejo Superior de Trabajo para nombrar sus vocales obrero y patronal en el Consejo de Estado, Lucio Martínez manifiesta en nombre de los demás consejeros obreros (socialistas como él) èl propósito de todos ellos de rechazar el cargo si el presidente no designa a quien ellos mismos indiquen, alegando que tal era la práctica del desaparecido Instituto de Reformas Sociales. Y señala ya a Largo Caballero como el individuo en quien ha de recaer el nombramiento.

Por parte de los patronos, Junoy se dice conforme con tal acuerdo. $Y$ el presidente lo acepta, aunque advierte que esto no supone renuncia a su derecho de designación, sino que consiente en ejercerlo en el líder de la U.G.T.

Ciertamente, como en el caso de los vocales del Instituto de Reformas Sociales, se trata de una aplicación analógica del criterio adoptado por la Unión y el Partido acerca de la exigencia de carácter representativo en los cargos oficiales. Ablación hecha de que el nombramiento legal sea propuesta del presidente y realización del rey (porque el rey firma todo decreto $u$ orden), en la práctica se impone el designio de los trabajadores.

Pero también es cierto, de nuevo como en el caso anterior, que esa aplicación analógica entraña una ampliación fáctica de los límites puestos por la U.G.T. para la aceptación de cargos. $\mathrm{Y}$ es claro, sobre todo, que tal ampliación obedece al deseo de 
copar los nombramientos en la medida de lo posible. De lo contrario no hubiera tenido sentido crear el consiguiente problema.

En otras palabras, lo que al principio aparecía como consecuencia de la pasividad de los socialistas ante el pronunciamiento, que les llevaba a poner condiciones al propósito de atracción del Directorio, se ha convertido en actividad positiva para escapar a los requisitos establecidos por ellos mismos y estar presentes en el mayor número de puestos oficiales.

Es imposible por ahora decir en qué grado ese esfuerzo obedece tan sólo al deseo de cumplir la finalidad puramente sindical de la U.G.T. en la mayor medida factible, o si responde además a un afán de verdadero acercamiento al régimen, que pudiera tener relación con el esbozo de proyecto laborista que acabamos de ver planteado a lo largo de estos mismos meses. En todo caso es obvio que el empeño parece realmente denodado durante el año 24.

Por lo demás, y dando muestras de que no se trata de un tema marginal, la Comisión Ejecutiva de la Unión General de Trabajadores se hace cargo de la cuestión y aprueba la gestión de los vocales del Consejo Superior de Trabajo en el asunto de la vocalía del Consejo de Estado.

En difícil equilibrio dialéctico, se insistirá más tarde en que lo que en esta ocasión se aprueba es la gestión: no el nombramiento en sí, en el que ni la sindical ni el P.S.O.E. "intervinieron ni tenían por qué intervenir» ${ }^{109}$. Parece intentarse de esta manera desproveer la decisión de toda apariencia de intencionalidad política y minimizar su significado:

Por su parte, el Comité Nacional de la propia U.G.T. aprueba a su vez la decisión de la Comisión Ejecutiva, con sólo el voto en contra del delegado de Vizcaya, «feudo» (¿lo hizo por esto?) de Indalecio Prieto.

Conforme a lo acordado, por último, el presidente del Consejo Superior de Trabajo propone oficialmente a Largo Caballero el 6 de octubre de 1924 . Alfonso XIII lo sanciona por orden del 13, que publica el 14 la Gaceta. Y el 25 los nuevos consejeros de Estado, entre ellos el socialista, toman posesión de su cargo.

En el acto, Largo Caballero elude el juramento de fidelidad

109 Saborit: Julián Besteiro, pág. $167 \mathrm{~s}$. 
al monarca y a la Constitución con estas palabras, sin duda acordadas previamente con las propias autoridades:

Mis convicciones en política y religión me imponen hacer toda clase de reservas sobre la fórmula del juramento que se me pide. Prometo haberme fiel y lealmente en el desempeño de mi cargo, procurar el bien de la nación y consultar, con arreglo a la Constitución y las leyes, en los negocios que me sean encomendados ${ }^{110}$.

\subsection{EL ENFRENTAMIENTO DE LOS INTRANSIGENTES}

Aunós sugiere con claridad la trascendencia del acontecimiento que acabamos de ver en la marcha del socialismo peninsular:

Hasta entonces su papel [el de los elementos políticos en el socialismo] había sido decisivo. A partir de este momento habrian de contar con los jefes sindicales "11.:

\subsubsection{Enfrentamiento de Indalecio Prieto}

En verdad, la postura de los socialistas intransigentes con la Dictadura se radicaliza en los mismos días, a lo largo de octubre de 1924, cuando se lleva a cabo el proceso del nombramiento legal de Largo Caballero.

El día 4, Indalecio Prieto escribe desde Bilbao, donde reside; al Comité Nacional del Partido Socialista, con sede en Madrid, un largo documento en donde toma posición de forma tajante:

Aun cuando, alejado de Madrid desde hace meses, no participo como vocal en las deliberaciones de ese Comité, me creo en el caso de dirigiros estos renglones para mostrar mi más absoluta disconformidad con la designación del compañero Largo Caballero para formar parte del Consejo de Estado en calidad de vocal obrero del Consejo de Trabajo, según he visto anunciado oficiosamente en $E l$ Sociatista.

110 Cit. Largo Caballero: Pasado y futuro..., pág. 46.

111 Aunós: Política social..., pág. 52. 
Desde el momento en que advino al Poder el Directorio he mantenido el criterio, reiterađo verbalmente y por escrito ante ese Comité, de que era indispensable un apartamiento acentuadísimo de los hombres del Partido respecto a los militares que encarnan el Poder, llegando para ello incluso a retirar de los organismos oficiales todas las representaciones desempenadas por afiliados.

Lo que en principio defiende es, por tanto, un criterio personal, probablemente justificado no sólo por el talante de Prieto, proclive al entendimiento con la izquierda liberal, sino también por el compromiso que cree supone para el socialismo su actitud, cara a un futuro restablecimiento de las garantías constitucionales.

Pero en el caso de la vocalía del Consejo de Estado está además implicado un criterio fijado objetivamente por el Partido:

... el cargo que va a desempeñar Largo Caballero y la forma en que se le elige no están dentro de las normas que hubo de señalar ese Comité cuando resolvió sobre la actitud que procedía adoptar en relación con el nombramiento de concejales.

Lo que ahora se va a hacer, al prestar asesoramiento desde Cuerpo consultivo tan alto como el Consejo de Estado y por hombre de tanta significación y el mérito de Largo Caballero a un poder dictatorial y arbitrario como el ejercido por el Directorio, equivale, a mi juicio, a aumentar, con gravísimo daño para el prestigio del Partido Socialista, el equivoco de una colaboración, que, si siempre será discutible tratándose de un Gobierno constitucional, procede rechazar de plano por toda clase de razones y conveniencias en las presentes circunstancias ${ }^{112}$.

Sin duda en busca de apoyo, Prieto envía su carta no sólo al Comité Nacional del P.S.O.E., sino también a Fernando de los Ríos. Y éste le contesta estar de acuerdo "en general» con ella y haber escrito ya a su vez al mismo Comité "otra carta oficial ... diciendo cuán penosa impresión me ha causado la aceptación por Largo Caballero del puesto de consejero de Estado.

Como veo en el hecho de aceptar todo lo que se ofrezca en organismos oficiales un error de probable trascendencia polí-

112 Apud $X I I$ Congreso..., pág. $140 \mathrm{~s}$. 
tica para el prestigio del Partido, les digo cuán necesario considero un apartamiento de cuanto pueda significar aquiescencia a las estúpidas reformas que hacen éstos, en las que, mediante un maquiavelismo rudimentario, tienden a complicar al Partido, y, por último, les propongo una consulta reservada a las Agrupaciones sobre la conducta a observar en estos momentos, en lo que a los cargos respecta» ${ }^{113}$.

Las dos cartas fueron leídas en reunión del Comité Nacional el 17 de octubre de 1924. Y el organismo acuerda consignar que considera el nombramiento en cuestión «ajeno a sus funciones, por haber sido hecho dentro de las normas trazadas por la Unión General de Trabajadores" ${ }^{114}$, que, por su parte, ya hemos visto eludiría también cualquier grado de competencia en ello.

En realidad, es bien sabido que Besteiro ${ }^{115}$ y los demás miembros del Comité Nacional apoyaban a Largo Caballero.

El 18, Saborit contesta a Indalecio Prieto en nombre del propio Comité:

Tu carta ha sido leída en la sesión de ayer, y constará en acta tu opinión.

La nuestra sigue siendo la que ya conoces. Pero en este caso concreto se acordó advertirte que no ha intervenido para nada la Ejecutiva del Partido Socialista en la designación del compañero Francisco Largo Caballero para el cargo del Consejo de Estado.

Es cosa propia y exclusiva de los vocales del Instituto de Reformas Sociales y de la Unión General de Trabajadores.

Podríamos dictar reglas a los afiliados del Partido para que se atuvieran a ellas; están dictadas, y el nombramiento que tratamos de Largo Caballero cae dentro de estas líneas generales ${ }^{116}$.

Las normas a que alude son las de 9 de enero acerca de la licitud de aceptar sólo cargos representativos.

113 Ibidem.

114 Saborit: Jutiân Besteiro..., pág. 168. Cf. Partido Socialista Obrero Español. Convocatoria y orden del día para el XII Congreso..., pág. 103.

115 Vid. Lamo de Espinosa: Op. cit., pág. 61.

116 Apud XII Congreso..., pág. 141. 
En verdad, la ruptura del socialismo no sólo toma vuelos internos, sino que comienza a tornarse en cuestión internacional. Por las mismas fechas de octubre, se habla concretamente en la prensa británica de la próxima formación de un Gabinete constituido por «socialistas moderados» bajo la presidencia de Primo de Rivera. Andrés Saborit, como secretario general del P.S.O.E., lo niega en nota enviada a los partidos socialistas y a la prensa extranjeros:

El Partido Socialista Obrero Español y Ia Unión General de Trabajadores de España no han colaborado con ningún Gobierno monárquico, no colaboran tampoco con el Directorio militar y no colaborarán mañana con el actual régimen político que en España existe.

La intervención de los socialistas en los diversos organismos oficiales del Estado está regulada por acuerdos de los Congresos y de los Plenos del Partido Socialista y de la Unión General, ...

Fiel a su tradición de lucha de clases y de independencia frente a todos los partidos políticos de la burguesía, el Socialismo español reclamia para sí el derecho a juzgar del momento y la oportunidad en que deba modificar su táctica ${ }^{17}$.

\subsubsection{Quiebra en la Ejecutiva del P.S.O.E.}

EI 25 de octubre de 1924, Largo Caballero toma posesión, veíamos, de la vocalía del Consejo de Estado...Y, el mismo día en que esto sucede, Indalecio Prieto dimite del cargo de vocal de la Comisión Ejecutiva del P.S.O.E. Lo hace por telegrama y por carta que publica El Socialista el $28{ }^{118}$.

A ta Comisión Ejecutiva del Comité Nacionat del Partido Sociatista Obrero Españot.-Madrid.

Estimados compañeros: Al conocer la noticia de haberse posesionado hoy el camarada Francisco Largo Caballero del cargo de consejero de Estado, os envié un telegrama anun-

117 Apud El Socialista, 25-X-1924.

118 Vid. Saborit (Julián Besteiro, pág. 168) y Aunós: Politica social..., págs. 51 ss. Alguno de los autores citados fecha Ia decisión de Prieto en 26 y no $25-X-1924$. Más importante es, sin embargo, el error que la data en 10-XII-1924, sin duda confundiéndola con otro hecho que tiene lugar este día, según veremos. 
ciándoos mi dimisión como vocal de la Comisión Ejecutiva.

Creo que el grado a que ha llegado mi disconformidad con vuestras resoluciones, en cuanto a la posición del Partido respecto al Directorio, no tiene la debida expresión con sólo salvar el voto y consignar la discrepancia verbalmente o por escrito, como he venido haciéndolo hasta ahora.

Hace historia de tal disconformidad y concluye que incluso sosteniendo las normas del 9 de enero, que sólo autorizaban cargos electivos, este no cae en tal supuesto:

... aunque Largo Caballero haya sido propuesto por Ios vocales obreros del Consejo de Trabajo, como vosotros alegáis, es evidente que su designación para formar parte del alto Cuerpo consultivo, en unión de los miembros del Directorio, corresponde al presidente de ese Consejo, y su nombramiento definitivo al rey. Es el actual el primer caso en que un militante del Partido Socialista acepta un cargo político por nombramiento de la corona.

Dimite, pues, del

cargo de vocal de la Comisión Ejecutiva, en mi deseo de mantenerme a. la mayor distancia posible de toda responsabilidad, directa o refleja, en el peligroso paso de autorizar a miembro tan significado en el Partido como Largo Caballero para que acepte un nombramiento de la corona y se allane a colaborar con el Directorio ${ }^{119}$.

La Ejecutiva del P.S.O.E. delibera sobre la carta de Prieto el 27 de octubre y, como la misiva ha tenido «cierto eco en la prensa», decide publicar una nota que reitera el criterio seguido hasta entonces:

«Digamos, ante todo - comienza-, que en el nombramiento de vocal del Consejo de Estado no ha tenido por qué intervenir la Comisión Ejecutiva del Partido Socialista, ya que tal designación correspondía hacerla a los elementos de la Unión General de Trabajadores, y más concretamente a los vocales obreros en el Consejo de Trabajo Estos, por otra parte, consultaron para ello a la Comisión Ejecutivà de la U.G.T., que respondió en sentido afirmativo, según comprobamos.

11 Apud XII Congreso..., pág. 151 s.: 
Existían -prosigue- unas reglas concretas aprobadas por las Comisiones de la Unión y del P.S.O.E.

«Según esos acuerdos, ningún individuo afiliado a alguno de ambos organismos podría aceptar cargos públicos que fueran otorgados por designación directa de los gobernantes, pero sí cuando, otorgados los puestos a las colectividades políticas o societarias a que perteneciesen, fueran éstas las que libremente los eligiesen.

Pues en virtud de esas normas ha sido elegido el consejero de Estado.»

La Comisión es consciente, al afirmarlo, de que el real decreto del 13 de septiembre pone en el presidente del Consejo de Trabajo la facultad del nombramiento. Pero lo cierto es que «la representación obrera - y en esto ha sido secundada por la patronal--, siguiendo las prácticas consuetudinarias en este organismo (sucesor del disuelto Instituto de Reformas Sociales), recabó en éste, como en todos los demás casos, su derecho a designar». Ella hizo el nombramiento y el presidente se limitó «a llevar los nombres de los designados al Directorio y éste a refrendar tales nombramientos por medio de real orden».

La nota elude, con una afirmación tajante, la cuestión de si esa ficción se ajusta con rigor a las reglas para la aceptación de cargos. Se ajusta, dice, porque, «idénticamente al nombramiento de consejero de Estado, se han hecho otros en todos los tiempos en diversos organismos, a todo lo cual se ha dado la oportuna publicidad, sin provocar ninguna protesta ni observación».

En cuanto al argumento, también aducido, de que la designación en litigio ha de ser realizada por real orden, también es ese el «procedimiento habitual en la mayor parte de los organismos en que figura la representación obrera, aunque sea ésta la que elija»: así en las vocalías del antiguo Instituto de Reformas Sociales o en la delegación ante la O.I.T. ${ }^{120}$.

En tal sentido contesta también a Indalecio Prieto, «en nombre de la Comisión Ejecutiva», su vicepresidente Francisco Núñez Tomás:

La Ejecutiva deliberó ampliamente acerca de su carta, y nuestra opinión queda consignada en la nota oficiosa hecha pública, y que remitimos a las entidades afiliadas al Partido. 
Subraya además que

en la interpretación de los acuerdos tomados por nuestro organismo hemos coincidido unánimemente los miembros presentes de esta Ejecutiva' ${ }^{121}$.

Más tarde, Largo Caballero advertirá a Prieto (y éste reconoce su error) que, en verdad, todos los nombramientos oficiales son realizados por decreto que suscribe la firma del rey, aunque éste no sea de hecho quien lleva a cabo la designación, y que el mismo Indalecio Prieto había sido miembro de la Junta de Aranceles y Valoraciones por decreto real ${ }^{12}$.

De momento, el vocal dimitido justifica su decisión en otro informe enviado a la Agrupación Socialista de Bilbao, del que remite copia el 15 de noviembre de 1924 al Comité Nacional del Partido ${ }^{123}$.

Pero éste vuelve a ratificar el acuerdo de la Ejecutiva:

Reunido el 10 de diciembre, el Comité aprueba, en efecto, por unanimidad, la aceptación por Largo Caballero de la vocalía en el Consejo de Estado. Y rechaza por 14 contra cinco votos la proposición de que los socialistas abandonen todo cargo político, además de aceptar la dimisión de Prieto ${ }^{124}$.

El 12, El Sol publica el informe enviado por el vocal cesante a la Agrupación de Bilbao ${ }^{125}$.

Al margen del pleito jurídico que en toda la cuestión se dirime, desde el punto de vista político, interesa ante todo un doble aspecto del asunto pormenorizado hasta aquí:

Por una parte, si vimos ya cómo en marzo de 1924 Indalecio Prieto iniciaba una larvada expresión pública de su disidencia

121 Apud XII Congreso..., pág. 153.

in Cf. ibidem, pág. 142 s., pág. 145.

123 Cf. ibidem, pág. 153, donde Prieto precisa que el propio Saborit le acusó de recibo de esa carta con fecha 18-XI-1924, comunicando a aquél que su escrito sería leído «en la primera sesión que celebre la Ejecutiva" del P.S.O.E.

124 Cf. Partido Socialista Obrero Español. Convocatoria y orden del día para el XII Congreso..., pág. 104. Los datos sobre la votación están confusos en Saborit (Julián Besteiro, pág. 168) y sobre todo en Aunós: Politica social..., pág. 51 ss. Vid. la reseña de la reunión en El Socialista, 11-XII-1924.

125 Cf. Virgilio Zapatero Gómez: Fernando de los Ríos: los problemas del socialismo democrático, Madrid, Edicusa, 1974, pág. 74. 
a través de El Socialista, la verdad es que es ahora cuando la polémica interior se exterioriza con toda su acritud e importancia. Comienza a divulgarse el hecho de que el socialismo se escinde (desde luego sin perder nunca la unidad organizativa).

Por otro lado, la resonancia del cargo discutido - una vocalía en uno de los organismos políticos, no ya profesionales, más importantes del Estado español- refuerza la interpretación temida por Prieto de que el propio socialismo colabora con la Dictadura, se supone que en virtud de acuerdos más o menos ocultos con el Gobierno.

De hecho, la especie exige rectificaciones públicas y tajantes, como la serie de diatribas Contra una falacia publicadas en El Socialista durante la primera quincena de noviembre de 1924, ante las acusaciones formuladas en aquel sentido por Gabriel Alomar. Su autor, Federico Landrove, expresa en ellas el criterio suscrito por los dirigentes del P.S.O.E. en favor de una actuación técnica en los medios oficiales, aséptica respecto a la política, pero no sólo con relación a la Dictadura, sino también a los oponentes considerados burgueses:

No se ha tenido ni tendrá, según él, «ni el más pequeño contacto con el Directorio militar, ni el más débil apoyo a esta dictadura, ni el menor asomo de colaboración a esta situación política y, lo que es mucho más valioso, ni la más remota complacencia ante la privación de las libertades públicas... Pero también, y por los mismos motivos, ... ni la menor inteligencia con los que desean restaurar el anterior estado de cosas» ${ }^{126}$.

La conducta seguida no puede «suponer colaboración con el Poder ejecutivo más que en el sentido extremo en que toda acción, sea de la índole que quiera, coadyuva con las demás a sostener en pie la vida de un país civilizado. En ese sentido sí hubo y hay, en principio, una colaboración; pero no con el Directorio militar ni con las fuerzas políticas que le sean afines, sino con la sociedad española, que no podía suspender su vida y renunciar indefinidamente a resolver sus problemas peculiares porque el Poder ejecutivo estuviese en unas o en otras manos» ${ }^{127}$.

En el mismo sentido, también en noviembre, insiste Largo Caballero en el propio diario ${ }^{128}$.

\footnotetext{
126 El Socialista, 9-XI-1924.

127 Ibidem, 11-XI-1924.

128 Vid. ibidem, 27-XI-1924.
} 
«Desde que se implantó la dictadura -dice un texto oficial de 1928-, la Comisión Ejecutiva no ha visitado a ningún ministro ni a ningún general encargado de despacho.

Por carta hemos gestionado la resolución que hemos creído de justicia en cada caso, dirigiéndonos casi siempre al ministro de Trabajo, ahora, y al secretario general del Directorio, antes, de quienes unas veces hemos recibido respuesta escrita satisfactoria y otras ni satisfactoria ni respuesta» ${ }^{129}$.

Lo que no es claro es que esta distancia formal fuese mantenida por todos los dirigentes socialistas.

La afirmación del colaboracionismo, de hecho, no sólo vendría de la oposición, sino de la propia Dictadura. Años más tarde, Calvo Sotelo lo aseguraba taxativamente:

«Yo he conversado en el despacho del general Primo de Rivera sobre problemas políticos de Asturias varias veces con el señor Llaneza»: en concreto, «sobre proyectos del Decreto-ley relativos a algunas minas» ${ }^{130}$.

Qué hubiera en ello, en todo caso, de colaboración propiamente dicha; hasta dónde llegó la relación y qué cuestiones fueron tratadas son preguntas a las que no es posible responder sobre los datos conocidos.

\subsection{LA INSISTENCIA DE LARgo CABALleRo}

Por lo demás, el talante renovador continúa en los mismos términos del prolaborismo del invierno anterior.

En el campo teórico, queda esto claro en un libro, Presente $y$ futuro de la Unión General de Trabajadores, fechado en enero de 1925, aunque sin duda redactado en el 24 , donde Largo Caballero explicita por tercera vez conocida sus ideas:

Subraya nuevamente la conveniencia de ampliar las atribuciones de aquella Comisión mixta electoral ya creada a «todo lo que tenga relación con los grandes problemas políticos que se presentan directamente a los dos organismos obreros nacionales».

129 Partido Socialista Obrero Español. Convocatoria y orden del día para el XII Congreso..., pág. 116.

130 Apud Diario de las Sesiones de Cortes, 16-VI-1936. 
No se trata con ello - advierte- de renunciar al ideario marxista, sino de realizarlo mejor:

Desde enero de 1888 a enero de 1920 , por precepto de los Estatutos, la Unión sólo tenía como aspiración alcanzar mejoras para los trabajadores, de carácter inmediato...

En cuanto al ideal político, los afiliados eran libres para adherirse a cualquier partido por muy reaccionario que fuese, dándose el caso, algunas veces, de que trabajadores que luchaban en el campo económico contra su patrono, en el político iban del brazo con él.

Pero, «al reformar los estatutos en 1919 en el XIV Congreso, se aprobó por unanimidad la declaración de principios, en la que se afirma el propósito de ... asumir ésta [la clase trabajadora] algún día la administración de la producción, el transporte, la distribución e intercambio de la riqueza social. Esta aspiración no es la anterior, sino diferente y completamente socialista, para cuya realización es indispensable salirse de los límites de la lucha económica y entrar de lleno en la acción política».

Había sido a partir de 1919 por tanto, según veíamos, cuando la U.G.T. comenzó a ser en realidad socialista. Hasta entonces había constituido una organización surgida y mantenida bajo el control del socialismo, pero sin adscripción a ésta ni a ninguna otra doctrina: en posición teórica única y exclusivamente sindicalista, que de hecho dio lugar a la adhesión (afirmada no sólo por Largo Caballero, sino por bien diversos autores, como el jaimista Severino Aznar) de obreros de las más variadas posturas, incluidos, desde luego, los católicos, que integraban la mayor parte del país.

No se trataba, pues - subraya Largo Caballero en su libro-, de abandonar de nuevo el programa socialista, sino de facilitar su cumplimiento:

La táctica de los trabajadores organizados no puede suje. tarse a un dogmatismo sectario, ni puede carecer de la flexibilidad necesaria para aplicarla en la forma que las imposiciones de la realidad política y condiciones económicas del momento aconsejen.

Tampoco se trata, sin embargo, de crear un nuevo partido, que encauce políticamente esta nueva orientación que Largo Caballero propugnaba así para la U.G.T. 
Eso significaría introducir en el proletariado una división suicida. El partido político de la clase obrera es y debe de ser el Partido Socialista. Lo que la Unión General deberá hacer es cooperar y colaborar con dicho partido en todo lo que coincidan; pero sosteniendo íntegra su autonomía, como hasta ahora, pues son muchos los matices que cada uno puede dibujar separadamente en la lucha por los ideales que persigue.

Era ante esa necesidad de una colaboración mayor, pero sin supeditación, donde mostraba todo su alcance aquel Comité mixto sugerido por el propio Largo Caballero en febrero de 1924 y cuya creación había sido aprobada en marzo por los Comités Nacionales del P.S.O.E. y la U.G.T., en principio sólo con fines electorales.

Seguro que el voto de las Secciones será favorable, y, en este caso, ya está iniciado el órgano mixto a que nos referíamos anteriormente.

... Habrá[n] de ampliársele las atribuciones para todo lo que tenga relación con los grandes problemas políticos que se presentan directamente a los dos organismos obreros nacionales.

... habrá de transformarse el periódico El Socialista en órgano oficial efectivo de las dos entidades, dirigido, redactado y sostenido económicamente por ambas.

De esta forma es como, a mi juicio, la clase obrera española podrá contribuir eficazmente a instaurar primero y después a afirmar en España un régimen político basado en la efectividad real del Parlamento, elegido por sufragio, sin restricciones de ningún género, y del Poder civil; en una legislación sobre enseñanza que tienda a agotar el vergonzoso analfabetismo que existe; en el pleno respeto al derecho de reunión y asociación; en la libertad de Prensa, la cual no deberá tener otra responsabilidad que la común; en la libertad religiosa, base fundamental para hacer posible el respeto mutuo a la conciencia ajena; en un derecho social referente a la propiedad de la tierra que haga posible que los obreros del campo no carezcan de los medios para vivir; en el exacto y leal cumplimiento de la legislación social, haciéndola extensiva a los trabajadores de la tierra, y en resoluciones que tiendan a la democratización de la industria, dando participación al factor Trabajo en la dirección y administración de la misma; la mejor manera de llegar a la más completa normalidad en la producción, del intercambio 
de ésta y a la estabilidad racional del precio de los productos; y, por último, para asegurar la posibilidad de que se transforme la sociedad presente, basada en la desigualdad social, en otra donde los hombres sean iguales en el punto de partida de la lucha por la vida, de tal modo que cada uno desenvuelva libremente su personalidad en igualdad de condiciones sociales y no pueda existir la explotación del hombre por el hombre ${ }^{131}$.

El programa que esquematizaba de este modo Largo Caballero, en enero de 1925, era sumamente significativo. Sin abandonarlo como meta final más o menos remota, apenas recordaba aquella declaración de principios del Congreso de 1919 que vimos proponía la socialización de los medios de producción como razón de ser de la U.G.T.

El programa de ahora, primero, recortaba implícitamente tales aspiraciones:

Empleando los propios párrafos transcritos, no hablaba de la asunción por los trabajadores «de la administración de la producción», como en 1919, sino de "participación» en la misma. Ni aludía tampoco a una socialización de la tierra y de los servicios, sino al propósito de conseguir que todos los campesinos tuvieran "medios para vivir» $\mathrm{y}$, en general, que se cumpliera y ampliase la legislación social.

Pero era más significativo aún, en segundo lugar, el énfasis puesto sobre la democracia en la enumeración de objetivos de 1925:

Ponía al frente de todos ellos la más completa democratización del sistema parlamentario, «sin restricciones de ningún género». Y no lo hacía así presentándolo como medio puramente circunstancial y transitorio para dar el poder a la clase obrera, sino que lo orientaba al establecimiento de determinados derechos individuales, formulados además en términos de rancio sabor liberal y paradójicamente individualista: libertad de reunión, asociación y prensa, sin más responsabilidad que la derivada del derecho común, y libertad religiosa como necesidad para «el respeto mutuo de la conciencia ajena».

El nuevo programa propuesto para el socialismo implicaba un acercamiento palpable a las reivindicaciones de total democratización del sistema manifestadas por la llamada izquierda

131 Largo Caballero: Presente y futuro..., págs. 237-249. 
burguesa sobre todo desde 1913 con la constitución del Partido Reformista. Era, de grado o de hecho, otro modo de expresar el pensamiento de Fabra Ribas sobre la ampliación del P.S.O.E. y podía entenderse, de esta manera, como una nueva oportunidad que parecía ofrecerse a la monarquía para hacer posible la revitalización del sistema en crisis: no porque el socialismo expresase aún a través del libro de Largo Caballero ninguna suerte de actitud gubernamental, sino porque olvidaba cualquier alusión al cambio de régimen y propugnaba por el contrario un conjunto de fines susceptibles en su totalidad de ser pretendidos a partir de los medios legales conformados por la Constitución de 1876.

De acuerdo con la interpretación peyorativa de Joaquín Maurín, el proyecto pretendía convertirse «en un factor decisivo de los acontecimientos. Primo de Rivera quería hacer un partido: la Unión Patriótica, y Largo Caballero anhelaba crear el suyo: el laborismo. Ambos estaban una vez más movidos por iguales propósitos. Serían las dos alas políticas de la "nueva" España. A la derecha, un bloque conservador, y a la izquierda, un partido de tendencias socializantes» ${ }^{132}$.

\subsection{VALORACIÓN GLOBAL DEL INTENTO}

Hay dos preguntas finales a formular sobre este interesante esbozo del laborismo español. Una concierne a sus orígenes y la otra a sus resultados.

Sobre la primera (qué influencias pudieron inducir o animar a Largo Caballero a exponer tales orientaciones) puedo decir tan sólo que, de una parte, estos hechos se dan durante la fase reformista del socialismo de Araquistáin ${ }^{133}$, cuya ascendencia posterior sobre aquel caudillo ugetista ha sido afirmada ${ }^{134}$ y cuya

132 Maurín: Los hombres..., pág. 186.

133 Aunque se centra en los años anteriores a la Dictadura, vid. la evolución que marca Raúl Morodo: Introducción al pensamiento politico de Araquistáin, «Boletín Informativo de Ciencia Política», núm. 7 (1971), págs. 17-34.

134 Aunque el adjetivo que le aplica únicamente es admisible precisando que sólo se refiere - si es así- a los años de la II República, Araquistáin ha sido presentado como «uno de los mentores stalinistas» de 
implicación en estos acontecimientos concretos desde las páginas de $E l$ Sol queda ya sugerida.

La otra influencia posible procede de Julián Besteiro, otro intelectual del Partido, miembro también de la U.G.T. y profesor de la Universidad de Madrid. Justamente entre 1919 y 1924 vive Besteiro «un período de progresivo acentuamiento de los aspectos fabianos de su pensamiento ${ }^{135}$, en el que se ha señalado asimismo una influencia positivista, neokantiana y kautskiana ${ }^{136}$, no menos moderada. Y a lo largo del propio año 24 se manifiesta pública y expresamente admirado ante la normalidad de la vida británica regida por el presidente laborista del Consejo de ministros de Su Majestad Ramsay Mac Donald ${ }^{137}$. Hay que advertir además que en estos años no hay siquiera presagios (todo lo contrario, según veremos) de su enfrentamiento de los años treinta con Largo Caballero.

Como probable coincidencia de criterio, más que como influencia, hay que advertir que los escritos de Pablo Iglesias en estos meses últimos de su vida insisten en la misma dirección, claramente alentado por el triunfo del laborismo inglés ${ }^{138}$.

Vayamos ahora a la segunda y última cuestión:

$¿$ ¿or qué no salió adelante el proyecto de laborismo esbozado por Largo Caballero?

Por de pronto, es preciso decir que la Comisión mixta elec-

Largo Caballero por Ricardo de la Cierva: La historia perdida del socialismo español, Madrid, Editora Nacional, 1972, pág. 150.

135 Emilio Lamo de Espinosa: Politica y filosofía en Julián Besteiro, Madrid, Edicusa, 1973, pág. 58 ss.

136 Paul Preston: The Origins of the Socialist Schism in Spain, 1917-31, «Journal of Contemporary», XII, núm. 1 (1977), 106.

137 Vid., por ejemplo, el artículo que reedita Andrés Saborit: El pensamiento politico de Julián Besteiro, Madrid, Séminarios y Ediciones, 1974, pág. 289 ss., publicado inicialmente en El Imparcial, 29-III-1924. Entre el 21-II-1924 (no 1923 como por error de imprenta se lee en Lamo de Espinosa: op. cit., pág. 59) y el 30-1X-1924, Besteiro vive en Inglaterra, becado por la Junta de Ampliación de Estudios para perfeccionarse como profesor universitario (cf. ibidem, 58 ss.). Sobre la personalidad de Besteiro, vid. asimismo Manuel Espadas Burgos: Sobre la figura politica de Julián Besteiro, «Hispania», núm. 119 (1971), págs. 593-611; Marta Bizcarrondo: Julián Besteiro, socialismo y democracia, «Revista de Occidente», número 94 (1971), págs. 61-76.

138 Vid. Pablo Iglesias: Escritos. 2. El socialismo en España. Artículos en la prensa socialista y liberal, Madrid, Ayuso, 1975, pág. 387 ss., 418 ss., 447 ss. 
toral nunca sirvió a su fin. La Dictadura no convocó jamás elecciones municipales.

«La Comisión Nacional, integrada por individuos de las Ejecutivas de la Unión General de Trabajadores y del Partido Socialista» - como la denomina Pablo Iglesias ${ }^{139}$-, se había reunido por primera vez al comenzar noviembre de 1924. La formaban Julián Besteiro - su presidente-, Largo Caballero -secretario-, el vicesecretario Lucio Martínez Gil y los vocales Saborit, Cordero y Fernández Quer ${ }^{140}$. Hasta 1927 al menos, se había congregado «muchas veces, publicó circulares e intrucciones, y contestó muchas cartas resolviendo dudas y consultas» ${ }^{141}$. Pero no parece que jamás se le dieran las atribuciones que el propio Largo Caballero pedía en su libro. De hecho, tres años después, el XII Congreso del Partido Socialista ratificó de forma expresa «el autonomismo de que goza» la U.G.T., contra cierta propuesta de la Agrupación de Logroño del P.S.O.E. «tendente a imponer determinadas normas de actuación a la Unión General de Trabajadores ${ }^{142}$.

En realidad, aquí parecía discutirse no la coordinación, sino la supeditación de la sindical. Pero no parece que la posibilidad de coordinar la acción de las dos organizaciones fuese planteada seriamente tampoco, ni allí ni en el Congreso de la U.G.T. del mismo año $28^{143}$.

A juzgar por la historia posterior, es obvio que Largo Caballero volvió a cambiar de criterio. En sus memorias cuenta que, siendo consejero de Estado bajo la Dictadura, Alfonso XIII lo invitó a asistir a un baile en la corte y que él rehusó. "No estábamos en Inglaterra - explica-, ni formábamos parte del partido laborista inglés» ${ }^{144}$.

139 Cf. ibidem, pág. 419.

140 Vid. El Socialista, 4XI-1924.

141 Partido Socialista Obrero Español. Convocatoria y orden del dia para el XII Congreso..., pág. 99.

142 Apud XII Congreso..., pág. 258.

143 Víd. ibidem y Unión General de Trabajadores. Actas de las sesiones celebradas por el XVI Congreso ordinario verificado en la Casa del Pueblo de Madrid en septiembre de 1928, Madrid, Gráfica Socialista, 1929, pág. $192 \mathrm{pp}$.

144 Francisco Largo Caballero: Mis recuerdos. Cartas a un amigo, México, Ed. Alianza, 1954, pág. 94. Hay una reedición española con prólogo y notas de Mauricio Carlavilla y una modificación injustificada del título: Francisco Largo Caballero: Correspondencia secreta, Madrid, Nos, 1961, pág. $332 \mathrm{pp}$. 
En cuanto a los motivos del abandono del proyecto no hay dato alguno. Maurín sugiere que «las circunstancias no eran propicias» ${ }^{145}$. Acaso esté la respuesta - o una de ellas- en la coetánea división del P.S.O.E. por la cuestión de la aceptación de cargos oficiales; división ahondada precisamente en los años 1924-1925. Aun predominando en el Partido entonces la postura del mismo Largo, favorable como se ha dicho a tal aceptación, no hay que olvidar que esta defensa de la presencia de los socialistas en los puestos representativos creados por el Directorio se apoyaba en cierta medida en la autonomía de los fines sindicales de la U.G.T. respecto a los fines políticos del P.S.O.E.: de forma que cualquier tipo de coordinación habitual hubiera podido ser inoportuna, dada la mera existencia de una oposición, aunque fuese minoritaria.

\section{La participación en los años 1925-1927}

Entre 1923 y 1925 los límites de la participación del socialismo en el poder han quedado fijados del modo que acabamos de ver:

Por un lado, la participación se limita a la aceptación de cargos oficiales para individuos de la U.G.T. o del Partido. No cuaja al fin aquella posibilidad de ir más allá: hasta la instrumentalización del propio Partido Socialista al servicio del juego político parlamentario con un hipotético empeño de acción incluso gubernamental.

Por otro lado, la aceptación de los cargos ha de ceñirse a las dos condiciones también señaladas: que los puestos sean verdaderamente representativos (o electivos, o cubiertos por decisión de la correspondiente organización socialista; nunca por designación directa del Estado) y que no impliquen equiparación de la U.G.T. con ninguna otra sindical.

La primera consecuencia de este planteamiento ha sido, ya en octubre de 1923 según vimos, la división de los socialistas. Esa división y los demás resultados de la participación en lo que atañe a la estructura de la Unión General y del P.S.O.E. entre 1925 y 1930 son los extremos a examinar ahora.

145 Maurín: Los hombres..., pág. 187. 


\subsection{NUEVAS CORPORACIONES OFICIALES}

A partir de 1924, el criterio mayoritario sobre los cargos parece inalterable. El socialismo sólo acepta puestos representativos por su designación, que, al tiempo, o sólo reconozcan a la U.G.T. el derecho a representar a los obreros o lo hagan sin equipararla a ninguna otra sindical.

Así, participan representantes de la Unión General en el Consejo Superior de Trabajo, y en la Comisión Delegada de las Corporaciones, entre otros organismos. Y por la misma causa continúan rechazando la presencia en el Consejo de la Economía Nacional, por negarse a reconocer el equiparamiento que en él se hace de su representatividad con la del Sindicato Libre y la de los Sindicatos Católicos.

El 9 de febrero de 1925, el vicepresidente del Consejo de la Economía Nacional se dirige en efecto a la U.G.T. para pedirle nombre un representante en la Conferencia de Minería. La Ejecutiva lo rechaza, conocedora de que se ha pedido también un enviado de los Sindicatos Católicos ${ }^{146}$.

Participa en cambio de forma plena (es esta acaso su mejor baza bajo la Dictadura) en la Organización Corporativa del Trabajo (que luego hemos de describir).

Creada por decreto de 26 de noviembre de 1926, la base sexta transitoria de tal norma autoriza al Gobierno para nombrar la primera Comisión Delegada de las Corporaciones con carácter interino. Previendo seguramente la negativa de los socialistas si la designación era realizada directamente por el Directorio, una real orden posterior dispone que los representantes obreros sean libremente elegidos por los vocales también obreros del Consejo Superior de Trabajo (lo que equivale de antemano a cerrar el camino a los demás sindicatos legales, si no estaban representados en él).

De hecho, los vocales en cuestión delegan en la U.G.T., cuya Ejecutiva designa a Saborit y a Largo Caballero como miembros

146 Cf. Unión General de Trabajadores. Convocatoria y orden del día del XVI Congreso..., pág. 11. 
efectivos de la nueva Comisión Delegada, y a Manuel Cordero y Trifón Gómez como suplentes.

La propia Ejecutiva decide además dirigir una circular a todas las secciones de la sindical socialista para aconsejarles que soliciten la constitución en sus respectivos oficios de Comités Paritarios, previstos en aquella Organización Corporativa del Trabajo.

El Comité Nacional de la Unión General de Trabajadores ratifica después tales medidas ${ }^{147}$.

En alguna ocasión vuelve a esbozarse el desacuerdo.

Así ocurre en un trámite de fecha desconocida, subsiguiente a la creación de la Junta Central de Abastos, que dependía del Gobierno civil de Madrid:

«... teniendo derecho la Unión General a nombrar un vocal efectivo y otro suplente», designa a Largo y a Cordero. Pero, «trasladada la Junta al Ministerio de la Gobernación, del cual había de depender en lo sucesivo, y no estando conformes con esa modificación, dejaron de asistir a las sesiones de nuestros representantes, por cuya razón el señor ministro designó a dos individuos del Sindicato libre para que los sustituyesen" ${ }^{148}$.

Pero en 1927 reaparece con mayor claridad el criterio excluyente.

Un decreto de 27 de febrero modifica la composición del Consejo de la Economía Nacional. Como en 1924, vuelve a conceder la misma representación a la U.G.T. y a los sindicatos católicos. Y aún amplía el derecho a la Confederación Nacional de Sindicatos Libres por nuevo decreto de 17 de marzo de 1927.

Reunido el Comité Nacional de la Unión General de Trabajadores, rechaza por tercera vez la participación en tal órgano ${ }^{149}$.

$\mathrm{Y}$ un problema cercano se plantea, en el invierno de 1927 a 1928, con el llamado "caso Arteaga».

\subsection{La ortodoxia, O El caso ARteaga}

Andrés Arteaga era miembro de la Junta de asociados para 1923 en el ayuntamiento de Madrid ${ }^{150}$. Pertenecía además al Sin-

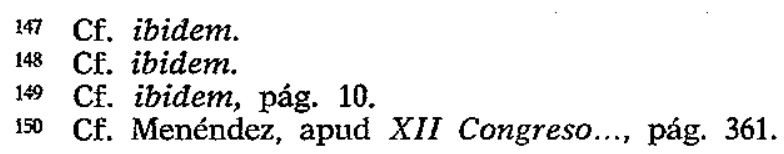


dicato Nacional Ferroviario y, solo desde el verano del propio año 1923, al P.S.O.E. ${ }^{151}$.

Dos meses después de esta inscripción en el Partido, obtuvo el cargo de concejal ${ }^{152}$, cuando, por disposición de primero de octubre, todos los ayuntamientos de la península fueron suspendidos y reconstituidos con los vocales asociados, según hemos visto.

Su nombramiento como edil pasó desapercibido en principio en la Agrupación Socialista madrileña: por ser Arteaga apenas conocido tras dos meses tan sólo de adscripción y porque su ignorancia de las normas del P.S.O.E. para estos casos no le hizo comprender la necesidad de comunicar de inmediato su designación como concejal ${ }^{153}$.

Pero después, identificado por sus correligionarios cuando la prensa empezó a encomiar su gestión, el Comité de la Agrupación de Madrid decidió seguir ocultando su filiación socialista para evitar que fuera destituido. La Dictadura - se alegaría luego- todavía se hallaba en el apogeo de la política represiva, que hacía temer tal actuación ${ }^{154}$.

El primero de abril de 1924 hubo una segunda renovación de ediles en el ayuntamiento madrileño, nombrados esta vez de modo directo por el gobernador civil, quien sin embargo permitió la continuación de Arteaga en su puesto, sin hacer cuestión de su nombramiento ${ }^{155}$.

Incluso se mantuvo el militante socialista en momentos difíciles. Nombrado segundo teniente de alcalde inmediatamente después de ser concejal, su labor en el cargo animaría a un grupo de «amigos particulares y políticos» a darle un homenaje en el Hotel Nacional el 11 de mayo de 1925. En el acto, se pronunciaron varios discursos -entre otros, el del propio Arteagacuyos términos molestaron a las autoridades. El entonces alcalde de Madrid, conde de Vallellano, suscitó un voto de censura contra él en sesión del ayuntamiento del 19. Arteaga dimitió en consecuencia de la tenencia de alcaldía, y lo habría hecho de la

151 Cf. Carrillo: ibidem, pág. 175.

152 Cf. Menéndez: ibidem, pág. 361.

153 Cf. Carrillo: ibidem, pág. 175.

154 Vid. Menéndez: ibidem, pág. 361, entre otros lugares.

155 Cf. Partido Socialista Obrero Español. Convocatoria y orden del día para el XII Congreso..., pág. 150. 
concejalía si el Comité de la Agrupación Socialista Madrileña no se lo hubiera desaconsejado ${ }^{156}$.

Más difícil aún, conseguiría mantenerse contra el parecer de un sector del Partido, que llegó a convertirlo en problema a nivel nacional. El 17 de junio del mismo año 25, la Agrupación Socialista de Valladolid en concreto dirige una carta a la Ejecutiva del P.S.O.E. con la finalidad expresa de cerciorarse de que el en ese momento discutido Arteaga fue en su día nombrado concejal de acuerdo con las reglas establecidas por la propia organización socialista o si se hizo con él alguna excepción. A petición de la Ejecutiva, la Agrupación de Madrid informa sobre el asunto, en el sentido de advertir que Arteaga figura, como vimos, entre aquellos vocales asociados que, por disposición legal de primero de octubre de 1923, pasaron automáticamente a ser concejales en sustitución de quienes hasta entonces ocupaban tal cargo. Se encuentra, por lo tanto, dentro de los límites establecidos por la Comisión Ejecutiva del Partido el 3 del mismo mes de octubre para la aceptación de ese cambio de puestos municipales.

En verdad, en su situación se hallan en tal momento otros curenta y cinco socialistas, antes vocales asociados y ahora concejales, a raíz de la disposición del día 1. Pero la personalidad del edil madrileño es objeto por esas fechas de la viva confrontación de fuerzas provocada por su discurso en su propio homenaje.

La Ejecutiva envía el escrito de Valladolid de 17 de junio de 1925 al Comité Nacional para que estudie la cuestión. Y éste decide dejar en libertad a la Agrupación Madrileña en la adopción del acuerdo definitivo. La Agrupación de Madrid lo discute «ampliamente» y "por inmensa mayoría de votos» opta por el mantenimiento de Artega en el cargo municipal, ordenándole que rinda cuenta trimestral de su gestión en él (como en efecto haría) ${ }^{17}$.

Sin embargo, el 19 de diciembre de 1927 el Gobierno civil de Madrid decide cesarlo: no sólo a él, sino también a todos los demás concejales madrileños. Se ven con ello envueltos en la crisis municipal provocada por ciertas acusaciones del alcalde Semprún contra una supuesta implicación del ministro de Hacienda, Calvo Sotelo, en hipotéticas irregularidades en la liqui-

156 Ibidem.

157 Ibidem, pág. 359 ss. 
dación del impuesto de plusvalía. Aunque esta acusación contra el ministro había sido formulada por el procurador del ayuntamiento a nombre sólo del alcalde, la destitución también de todos los ediles «fue una necesidad política del Gobierno», a fin de poder elegir libremente los nuevos concejales y evitar de este modo tener que designarlos entre los suplentes nombrados por Semprún, «a quien, por lo que se ve, no acompañó el acierto ni aun en este detalle».

En esa nueva elección de los componentes del ayuntamiento de la capital, el Gobierno civil volvió a designar a Arteaga. Y éste consultó la aceptación a la Agrupación Socialista local. A juicio del interesado, procedía la continuación en el puesto, «para ventilar incidentes surgidos en la etapa edilicia del S[eño]r Semprún, y también por considerar idéntico este nombramiento de ahora con los casos anteriores de renovación municipal [de Madrid, en primero de abril de 1924], en que él no fue renovado" ${ }^{158}$.

El mismo criterio mantuvo una minoría en la Agrupación madrileña, por ser «las circunstancias que rodean el nombramiento de concejal hecho recientemente por el gobernador civil de la provincia... iguales o muy parecidas a cuando fue elegido concejal primeramente, y en atención al acuerdo adoptado ya por la Agrupación Socialista Madrileña declarando la conveniencia de que esté en el Ayuntamiento" ${ }^{159}$.

No así la mayoría, por considerar que la designación «de carácter gubernativo» que se debatía "no se ajusta a los acuerdos $\mathrm{y}$ a las normas fundamentales que con este motivo tiene adoptados y ratificados el Comité Nacional del Partido" ${ }^{160}$.

Convocada al efecto asamblea extraordinaria de la Agrupación, la tesis desfavorable de la mayoría del Comité local triunfó por 128 votos contra 25. Pero, comunicada a Arteaga, respondió éste «con una nota, que hizo pública en la prensa, diciendo que seguiría fiel a las ideas socialistas, pero que consideraba de su deber no abandonar el Ayuntamiento de Madrid en momentos en que necesitaba reivindicar su honra».

El Comité, «por unanimidad», acordó separarlo del P.S.O.E. ${ }^{161}$.

158 Ibidem, pág. 363. Cf. ibidem, pág. 357 ss.

159 Declaración reproducida ibidem, pág. 364.

160 Reproducida ibidem.

161 Ibidem. 


\subsection{LA REBELDÍA}

El caso Arteaga, aparentemente, podía interpretarse como anecdótica prueba de rigor en el socialismo, que velaba de esta manera por el cumplimiento de sus disposiciones internas. Pero, de hecho, éste y los otros nombramientos (incluso los llevados a fin dentro de las bases estipuladas) continuaban ahondando la escisión en sus propias filas.

Dentro de la laxitud con que la Dictadura atempera la vida de las agrupacines políticas, algunos grupos e individuos manifiestan de modo abierto, hasta la rebeldía, su oposición a la presencia de los cargos públicos.

El caso mejor conocido y más resonante es el de la Agrupación Socialista de Valladolid.

Por lo menos en 1924 muestra ya un evidente recelo ante todo lo que concierne a la participación en las corporaciones oficiales. Primero, se trata del prurito de que esa presencia se ajuste de forma estricta a las normas impuestas por la Comisión Ejecutiva y el Comité Nacional del P.S.O.E. Después, llega a poner en duda la propia validez de esas normas.

En la primera línea hay que entender, por ejemplo, el artículo del vallisoletono Landrove, donde en dicicmbre de 1924 pide que la aceptación de la vocalía en el Consejo de Estado sea sometida a referéndum interno. La dirección de El Socialista se niega a publicarlo. Y la Agrupación de la ciudad castellana protesta oficialmente ${ }^{162}$.

Después, en junio de 1925, interviene en el caso Arteaga del modo que acabamos de ver.

Pero, a la vez en que esto ocurre, da ya el segundo paso que anunciamos: no discute tan sólo si las normas se cumplen, sino la licitud de las mismas normas.

En asamblea general convocada al efecto para el 28 de julio de 1925, "con asistencia de la casi totalidad de los afiliados»; aprueba "por unanimidad» ${ }^{163}$ el primer anuncio de rebeldía expreso en la siguiente proposición:

162 Cf. ibidem, pág. 325.

163 Carta de la Agrupación Socialista de Valladolid a la Comisión Ejecutiva del P.S.O.E., 3-VIII-1925, ibidem, pág. 321. 
La Agrupación Socialista de Valladolid acuerda no inspirar su conducta en otras normas disciplinarias que las trazadas por los Congresos del Partido, aceptando, sin embargo, los acuerdos del Comité Nacional en cuanto no pugnen con el criterio de la misma; pero reservándose en todo caso el derecho a interpretar libremente unas y otros. La Agrupación Socialista vallisoletana funda su decisión en el hecho de que, a su juicio, las decisiones de los organismos directivos del Partido - Comisión Ejecutiva y mayoría del Comité Nacional- no se ajustan a las resoluciones de los Congresos ni a las normas tradicionales del Partido Socialista ${ }^{164}$.

La detonante declaración es enviada el 3 de agosto a la Comisión Ejecutiva del P.S.O.E., pero también a la prensa. El Socialista no la publica; El Sol no la recoge íntegra, y la dirección de La Libertad consulta su inclusión a Pablo Iglesias, que deja libre al periódico para hacer lo que quisiera ${ }^{165}$.

En reunión del 7, la Comisión decide recordar formalmente -en carta del 8- a Valladolid «que con arreglo a la organiza. ción del Partido Socialista, la Ejecutiva y el Comité Nacional, según los casos, representan a aquél cuando no está reunido en Congreso ${ }^{166}$.

La Agrupación castellana no sólo no rectifica su postura, sino que, a mediados de diciembre de 1925, envía una circular a todas las demás asociaciones del P.S.O.E., donde transcribe su declaración del 28 de julio y añade estos motivos para justificarla:

Que algunos socialistas han aceptado cargos en corporaciones públicas por «nombramiento indirecto, sin consultar previamente con el Partido y sin someter lo hecho al referéndum de las Agrupaciones» (tal como había pretendido Landrove ante la aceptación del cargo de consejero de Estado).

Que a veces esos cargos no son siquiera de nombramiento indirecto ( $\mathrm{si}$ se entiende por tales los indirectamente realizados por las propias Agrupaciones o por el Partido).

"Que la Administración del Partido es sensiblemente costosas.

Que la orientación de El Socialista resulta inadmisible: por la ineptitud de algunos redactores y por la intromisión de la

\footnotetext{
164 Reproducida ibidem, pág. $321 \mathrm{~s}$.

165 Cf. ibidem, pág. 322.

166 Carta de Saborit a la Agrupación Socialista de Valladolid, 8-VIII1925, ibidem, pág. 322.
} 
dirección en la selección de lo que se publica, de manera que informa parcialmente e impide el derecho de crítica contra la Ejecutiva y el Comité Nacional.

"Que se observa, en algunos actos de ciertos elementos dirigentes del Partido, un principio de poder personal, corruptor e incompatible con las normas de austeridad y democracia que siempre se siguieron entre nosotros.»

Que «el Comité Nacional no es, realmente, representación fiel del Partido", porque los delegados regionales se hallan en minoría, y en la práctica, son los miembros de la Ejecutiva quienes deciden con sus votos.

"Convencida de que ello es perfectamente inútil, la Agrupación Socialista vallisoletana no reclamará ya nada contra aquélla ante el Comité Nacional. Reclamará ante el Congreso del Partidos ${ }^{167}$.

Prudente en ello, la Comisión Ejecutiva del P.S.O.E. responde a este documento con otra circular, enviada también a las Agrupaciones, en términos notablemente mesurados:

Se sorprende del escrito vallisoletano (que conoce indirectamente, por comunicación de la Agrupación Madrileña), "puesto que la citada colectividad vallisoletana jamás se ha dirigido a nosotros en demanda de que corrijamos o enmendemos los males que apunta».

Hace memoria de los hechos que han podido motivar el enojo; pero no insiste en ellos. «En los presentes momentos, ... sería un delito de leso socialismo que la Comisión Ejecutiva se entretuviera en defender su gestión de los ataques de la Agrupación de Valladolid... En su día, democráticamente, con serenidad de espíritu, se juzgará todo y el Partido Socialista sabrá hacer a unos y a otros la justicia debida.»

En tanto, pide a los disidentes («con quien[es] seguimos manteniendo relaciones oficiales de cordialidad») la rectificación de su postura ${ }^{168}$.

En sentido parejo, la misma Ejecutiva escribe a Valladolid el 4 de enero de 1926, con más fuerza y detalle. «Respecto a vuestro propósito de no reclamar ya nada ante el Comité Nacional, os advertimos del peligro que entrañaría, pues significaría colocarse abiertamente contra la disciplina del Partido, y ello comprenderéis que no podemos pasarlo sin pedir una rectifica-

167 Reproducido ibidem, pág. 323 s.

168 Reproducido ibidem, pág. 326. 
ción terminante.» Pero se ofrece a mandar antes una representación a aquella ciudad «a dar cuenta de nuestra gestión, a título documentativo, ante la propia asamblea de la Agrupación Socialista de Valladolid ${ }^{169}$.

El día 8, la Comisión acuerda además convocar el Pleno del Comité Nacional del P.S.O.E., para el 10 de febrero, y lo comunica el 9 de enero a Valladolid para que envíen un comisionado o faciliten toda clase de antecedentes al delegado de Castilla la Vieja, Remigio Cabello ${ }^{170}$, miembro por otro lado de la propia Agrupación rebelde.

Todavía en enero, reunida ésta en asamblea general, aprueba una pública declaración en la que niega la división del Partido de que comienza a hablarse en la prensa a raíz de estos hechos. Y asegura que aceptará en su día la correspondiente decisión del futuro Congreso, cualquiera que ella sea. Pero no alude para nada a la inmediata convocatoria del Comité Nacional. La Agrupación «irá con su criterio al Congreso del Partido, que es donde reside la máxima, si no la única, autoridad orgánica» ${ }^{171}$. No parece tener intención, por tanto, de enviar representación al Pleno que acabamos de ver anunciado al efecto. Y, al menos, de hecho advierte en nueva carta a la Ejecutiva que no acepta el envío de un informador in situ, tal como se les había ofrecido el $4^{172}$.

El 10 de febrero de 1962, el Comité Nacional se reúne efectivomente sin delegación especial de Valladolid. Incluso el socialista Cabello (que se solidariza con la postura de la Agrupación castellana, de algunos de cuyos acuerdos se reconoce expresamente responsable), advierte «que no está autorizado por la Agrupación Socialista de Valladolid para intervenir en este pleito». $\mathrm{Y}$ «se inhibe en absoluto» reiteradamente durante la reunión.

El debate en ese Pleno del 10 -si cabe denominar debate a una serie de intervenciones sin contradictor- se mueve en un paradójico campo dialéctico, en el que nadie quiere en principio proponer decisiones que produzcan la quiebra. Largo Caballero razona la incoherencia de que la Agrupación cuestionada diga acatar los acuerdos de los Congresos pero no los de la Ejecutiva y el Comité Nacional, cuya autoridad ha dimanado precisamente de los propios Congresos. $\mathrm{Y}$ afirma que, si la Agrupación y Ca-

169 Reproducido ibidem, pág. 327.

170 Cf. ibidem, pág. 327.

171 Reproducida ibidem, pág. 328.

172 Cf. ibidem, pág. 329. 
bello se inhiben en el Pleno, es porque nada tienen que decir, ni procede tampoco por tanto acudir a informarles in situ ni aceptar luego la discusión en el futuro Congreso del Partido.

Se dibujan después cinco propuestas:

Cabello sugiere «que una Comisión del Comité Nacional vaya a Valladolid o que se apliquen las sanciones que indica la organización» (de modo que, otra vez paradójicamente, se ha adscrito a la postura rebelde al tiempo en que admite de hecho la posibilidad incluso de la expulsión).

Suárez reclama «que se dé un plazo [a Valladolid] para ponerse en relación con la Ejecutiva o que se les dé de baja».

Toyos pide "que la Ejecutiva haga una nueva tentativa, y si no triunfa, se suspendo de derechos a la Agrupación Socialista de Valladolid».

«Saborit... dice que si el Pleno aprueba la conducta de la Ejecutiva, se evite, por el momento, imponer sanciones».

Por último, «Lucio Martínez propone que se nombre una ponencia que redacte una propuesta en la que se den a aquellos compañeros, si previamente se comprometen a acatar la Organización general, todas las facilidades necesarias, y en caso contrario, aplicarles la debida sanción».

Triunfa por fin, de hecho, la postura de Saborit, que la dirá fundada en la inoportunidad de dar "una campanada» en un momento tan favorable para la difusión del socialismo ${ }^{173}$. Concretamente, el Pleno acuerda una declaración en la «que aprueba las gestiones realizadas por la Comisión Ejecutiva con la Agrupación Socialista de Valladolid». Advierte a ésta el deber de «acatar y cumplir los acuerdos del Comité Nacional». Se considera relevado del deber de rebatir las acusaciones, en vista de la inhibición de los rebeldes. $Y$ se ofrece «a designar una Comisión de su seno que, sin que esto sirva de precedente, se persone en Valladolid a explicar y defender, si fuera preciso, la conducta de este organismo nacional" ${ }^{174}$. Incluso nombra ya a los comisionados: Suárez, Osorio y, por la Ejecutiva, Saborit ${ }^{175}$.

Estos se ponen de inmediato en relación con el Comité de la ciudad castellana, que sin embargo les contesta que juzga «inútil [la] presencia [de la] Comisión en Valladolid»" ${ }^{176}$.

Los Comisionados lo notifican a la Ejecutiva el 13 de febrero

173 Acta del Pleno, ibidem, págs. 328-331.

174 Reproducida ibidem, pág. $332 \mathrm{~s}$.

175 Cf. ibidem, pág. 333.

176 Telegrama, ibidem, pág. 333. 
de 1926. Y los dirigentes del P.S.O.E. parecen optar por ignorar el problema. Nada menos que un año después, el 23 de febrero de 1927, el Comité Nacional acuerda proponer expresamente al Pleno que el tema sea dejado y silenciado hasta el futuro Congreso ${ }^{17}$.

Evidentemente, se cree inoportuno su replanteamiento, sea por mantener el auge del Partido (conforme a las afirmaciones de Saborit), sea en realidad por evitar una quiebra total, que acaso arrastraría otras Agrupaciones. Al menos de la de San Sebastián se sabía en 1926 que «haría suya la propuesta de Valladolid, en el caso de que esta Agrupación no la mantuviese» ${ }^{178}$. Y la de Cartagena se adhirió formalmente a la conducta vallisoletana. Las demás callaron o condenaron a aquélla ${ }^{179}$.

\section{Consecuencias}

\subsection{LA ACCIÓN REIVINDICATIVA}

Sobre la eficacia que tuvo para la política obrera española (no ya para la vida del obrero, que constituye otro tema) esta participación en los cargos oficiales bajo la Dictadura, los juicios no son unánimes pero sí generalmente positivos.

Aunque el hecho más debatido, por razones políticas, fuera la aceptación de la vocalía en el Consejo del Estado, lo más eficaz fue acaso la intervención en la Organización Corporativa del Trabajo:

«A partir del 26 de noviembre de 1926 -escribe un socialista-, las organizaciones de la Unión General recobraron su actividad, $y$, con el lema general de los Comités paritarios, se dieron millares de conferencias... Muchos gobernadores y alcaldes advirtieron esa hábil propaganda y la prohibieron ${ }^{180}$.

17 Cf. ibidem.

178 Acta del Pleno de 10-II-1926, ibidem, pág. 330.

179 Cf. ibidem, pág. 330 .

180 Enrique Santiago: La Unión General de Trabajadores ante la revolución, Madrid, Sáez Hermanos, 1932, pág. 25. El propio autor escribe en términos un tanto confusos: «Conste ..., una vez más, que el Partido Socialista no tuvo el menor contacto con la dictadura. En cambio, la 10 
Si fueran contabilizados los actos de propaganda realizados por socialistas bajo la Dictadura -reconoce Maurín--, «sumarían centenares y centenares. Les fue concedida libertad completa de acción. Delegados y propagandistas recorrían la Península de un extremo al otro cantando las excelencias de la socialdemocracia» ${ }^{181}$.

Por su parte, el propio Pablo Iglesias hace públicamente este recuento de lo logrado en el campo organizativo, sólo entre septiembre de 1923 y mayo de 1925:

A pesar de la censura, de las frecuentes limitaciones a los derechos de asociación y de reunión y de las trabas puestas a la acción huelguística, ni el Partido Socialista ha visto clarearse sus filas, ni la Unión General de Trabajadores ha notado merma alguna en sus huestes. Por el contrario, el trabajo realizado, aun dentro de $\tan$ mal ambiente, ha servido no sólo para fortalecer el espíritu de los individuos que integran ambas entidades, sino para incrementar sus fuerzas.

\section{Y concreta:}

En los dos años últimos el Partido Socialista ha aumentado el número de sus Agrupaciones y su órgano en la Prensa el de sus compradores y abonados.

En ese mismo tiempo la Unión General de Trabajadores ha visto acrecer el número de sus Secciones y llevar excelente marcha a los Sindicatos o Federaciones de industria.

En dicho periodo, el Sindicato Nacional Ferroviario, que pertenece a la Unión General, ha alcanzado brillantes triunfos enviando al Tribunal Central y a Ios Tribunales Regionales de Ferrocarriles representantes de su confianza.

En los dos años citados, el Sindicato Minero de Asturias, también adherido a la Unión General, ha hecho frente victoriosamente a dos acometidas de los dueños de minas pretendiendo rebajar los salarios y elevar la jornada.

Nunca como desde que existe el Directorio ha penetrado tanto en las organizaciones obreras el pensamiento de que deben ejercitar la acción política para mejor defender sus intereses y acelerar el momento de la emancipación proletaria ${ }^{182}$.

Unión General de Trabajadores sí le tuvo [sic], a partir del 26 de noviembre de 1926, creando la Organización corporativa» (ibidem, 23).

181 Maurín: Los hombres..., pág. 189.

182 Apud Iglesias: Escritos. 2, pág. 419, o El Socialista, 12-V-1925. 
Los argumentos de los detractores no son, con todo, deleznables. Por una parte, la actividad de las organizaciones de reivindicación obrera fue sin duda menor:

Respecto a «la afirmación de que ahora se respetan las organizaciones obreras, y que en otros tiempos había deportaciones y encarcelamientos —advierte Indalecio Prieto en 1928-... ¿ es que están ahora los organismos en pie de lucha? Es que si lucharan las organizaciones, ¿serian respetadas? Cuando ha habido conatos de lucha, ... han sido deportados compañeros nuestros y encarcelados» 183 .

La relación de destierros y actos públicos suspendidos a la U.G.T. y al Partido Socialista entre 1923 y 1928 es desde luego importante ${ }^{184}$. Pero el silencio o la parquedad de sus órganos directivos no permite tampoco valorarlo excesivamente.

Por otro lado, lejos de obtener siempre sus reivindicaciones, los Comités Paritarios sufrieron a veces (en verdad las acusaciones concretas son pocas, pero las hay) la intromisión, sobre todo de los Gobiernos civiles ${ }^{185}$.

En numerosas ocasiones, las propias secciones de la U.G.T. hubieron de declarar la huelga para obtener mejoras laborales que no conseguían por medios legales.

No hay datos suficientes para valorar los resultados de estos enfrentamientos.

La huelga de 9.000 obreros de la metalurgia bilbaína, en julio de 1925, es resuelta por un comité mixto.

La de los trabajadores de la empresa Ibero-Tanagra en el lugar santanderino de Adarzo, entre octubre del 25 y noviembre de 1926, fracasa.

Otra comisión mixta resuelve la dirigida por la Sociedad de Canteros de Vigo entre agosto de 1926 y mayo de $1927^{186}$.

En Asturias, las buenas relaciones entre Llaneza y el dictador debieron contribuir a una cierta suavización en la actitud de ambas partes. En noviembre de 1924, con todo, el intento patronal de disminuir los salarios, afectados así por la contracción de la demanda hullera tras la primera guerra mundial, lleva al Sindicato Minero que aquél dirige a declarar la huelga gene-

183 Prieto, discurso apud XII Congreso..., pág. 190.

184 Vid. Partido Socialista Obrero Español. Convocatoria y orden del dia para el XII Congreso..., pág. 245.

185 Vid. XII Congreso..., passim.

186 Cf. Unión General de Trabajadores. Convocatoria y orden del día del XVI Congreso..., pág. 21. 
ral. Iniciada el 17, cesaba una semana más tarde, en términos que fueron presentados en la prensa socialista como un rotundo éxito sobre empresarios ${ }^{187}$. Lo que había ocurrido es que «el presidente del Directorio ofreció una fórmula, que fue aceptada» por todos.

En 1927, la situación sigue siendo grave no obstante. El Gobierno decide prolongar la jornada minera de siete a ocho horas desde el 1 de octubre; lo cual —alegan los socialistas-, «lejos de atenuar el conflicto, le ha agudizado, lanzando al paro a la mayoría de los obreros».

El 17 de octubre, el Sindicato Minero socialista vuelve a ordenar por tanto el paro general en las minas de la región. El Directorio reconoce en parte, en nota que se hace pública, la razón que asiste a los trabajadores. $\mathrm{Y}$, unos días después, el conflicto queda resuelto «de acuerdo con el Gobierno y con los patronos, evitando la rebaja de los salarios».

En conjunto, según la Ejecutiva de la U.G.T., «el Sindicato Minero Asturiano ha hecho una admirable gestión en estos cuatro años de dictadura [de 1923 a 1927], soslayando los peligros de una política de agresividad por parte de los patronos, a quienes favorecian las circunstancias políticas y la pérdida de la huelga inglesa ${ }^{188}$ sin duda la de 1926.

En el Reino Unido, en efecto, el descenso de las exportaciones hulleras tras la Gran Guerra había inducido a los empresarios a practicar una política de disminución de los salarios y aumento de la jornada laboral, que motivó en el año 26 la declaración de huelga general por parte de los mineros, secundados por los ferroviarios y los estibadores.

A los ocho días, no obstante, la orden de paro era retirada por las Trade Unions, al parecer por las vacilaciones de los pro-

187 Vid. El Socialista, 18 a 25-XI-1924.

188 Partido Socialista Obrero Español. Convocatoria y orden del día para el XII Congreso..., pág. 116. Según La Cierva (op. cit., pág. 117), "Llaneza celebró con Primo de Rivera una entrevista resonante, de la que surgió la primera gran experiencia de socialización industrial de España: la famosa mina de "San Vicente», en el valle de Langreo, con Amador Fernández como gerente y Belarmino Tomás como director de los trabajos interiores. La gestión fue un éxito social y económico y se rubricó en la sesión del Consejo de Ministros -agosto de 1929- en la Diputación Provincial de Oviedo, con la aprobación y puesta en marcha de varias medidas propuestas por Manuel Llaneza y encomendadas a la gestión del Sindicato Minero". Habla de ello Andrés Saborit: Asturias y sus hombres, Toulouse, Ediciones U.G.T.-C.I.O.S.L., 1964. 
pios dirigentes sindicales y la falta de solidaridad de los obreros. Influyó en ello también las dificultades de comunicación entre los huelguistas (paradójicamente acentuada por la decisión de secundar el paro por parte de los impresores, cuyo trabajo permitía la difusión rápida de las noticias sobre la propia huelga). $Y$, en último término, influye la habilidad del Gobierno Baldwin para asegurar la continuidad en la vida económica mediante la correspondiente maquinaria gubernamental de emergencia.

Sólo los mineros continuaron el conflicto durante ocho meses.

Al cabo, el fracaso fue coronado por la tendencia revanchista de algunos patronos a tomar represalias contra los obreros y por una drástrica política antisindical del Ministerio, concretada ante todo en la ley de huelgas de 1927, que consideraba delictivo el paro que desbordara los límites de una industria (la huelga general, por tanto) o que se enfrentase al Estado (no sólo al sector privado), además de prohibir la participación de los funcionarios públicos en huelga alguna o en agrupaciones que estuvieran asociadas al Congreso de las Trade Unions ${ }^{189}$.

A la larga, la mala impresión causada por estas medidas contribuiría a la caída del Gobierno Baldwin tras su derrota en las elecciones de 1929, que llevaron al poder al segundo Ministerio presidido por Ramsay Mac Donald. Pero, en el ínterin (19271929), el movimiento obrero internacional, y en él el español, tuvo motivos para considerar la situación como adversa.

No sería tal sin embargo en España.

En efecto, las cifras sobre producción y salarios en la minería peninsular durante estos años dan pie a una hipótesis de trabajo (no desde luego a una conclusión) de no escaso interés:

Disminuyendo la producción y los conflictos, los logros laborales parecen ser aceptables.

Veamos el primer factor:

La producción hullera española aumenta durante la primera guerra mundial. La impulsan las necesidades propiamente bélicas y los problemas de abastecimiento inherentes al conflicto armado, que contribuyen a provocar un alza en los precios que hace particularmente rentable la extracción.

189 Vid. Anthony Mason: The General Strike in the North East, Hull, University of Hull Publications, 1970 , VI +116 págs., y Patrick Renshaw: The General Strike, Londres, Eyre Methuen, 1975, 301-págs. 
Importa insistir una vez más en el hecho (de consecuencias laborales obvias) de que ese aumento se realiza no tanto por mejoras de equipo como por la ampliación de la mano de obra: de 30.000 a 60.000 obreros entre aquellas dos fechas.

A lo largo de la década de los veinte la producción continúa el ritmo expansivo. Pero no el consumo. Se esboza así en España la crisis provocada por los excedentes ${ }^{190}$.

Pues bien, en estos años de recesión, entre 1925 y 1930, la minería del carbón es, en cambio, tras la industria textil y a la par de la siderurgia, el sector que registra mayor aumento en los salarios reales, con alza de quince puntos en los índices.

Por zonas, Asturias ocupa el quinto lugar en la relación de crecimiento del salario real por provincias entre 1914 y $1930^{191}$.

Aunque estas cifras exigirian sin duda una comprobación rigurosa, y lo mismo la anterior deducción por tanto, la influencia de la actividad de los socialistas en esa dinámica no parece haber sido en especial pujante, al menos por su peso numérico.

Los afiliados a la U.G.T., estancados prácticamente entre 1920 y 1928 a escala nacional, descienden sin embargo en Asturias de 18.147 en 1922 a 12.808 en $19288^{192}$.

Respecto al P.S.O.E., "la Federación Socialista Asturiana votó en el Congreso de la escisión [en 1919] por 1.380 afiliados» ${ }^{193}$. En el de 1921 habían disminuido ya a 876; 496 en marzo de 1923; 375 en 1925; 243 en agosto de 1927, para recuperarse levemente, hasta 392 en octubre del mismo año y 422 al comien-

190 Los conocidos datos de Vicens Vives sobre la producción hullera en estas fechas difieren totalmente de los que da David Ruiz: op. cit., pág. $47 \mathrm{~s}$. En tanto no sean revisados, no es posible por ello consignar ninguno.

191 Cf. Ministerio de Trabajo. Estadística de salarios y jornadas de trabajo referida al periodo 1914-1930, «Revista de Trabajo», núm. 1 (1965), pág. 240 ss. Lamentablemente, la reedición de esta importante fuente es incompleta respecto a la primera versión, aparecida en 1930. Es necesario por lo tanto emplear esta última para un estudio más detenido. Por otra parte, no es posible olvidar la crítica de los datos sobre precios y salarios elaborados por el Instituto de Reformas Sociales para el periodo 1914 1922 e incluidos luego parcialmente en esta publicación del Ministerio de Trabajo; crítica concretada por Roldán...: op. cit., I, pág. 138 ss., 180 ss.

192 Cf. Unión General de Trabajadores. Convocatoria y orden del XVI Congreso..., pág. 88.

193 Cf. Partido Socialista Obrero Español. Convocatoria y orden del día para el XII Congreso..., pág. 192. 
zo de $1928{ }^{194}$. "Después de siete años de crisis de trabajo, es un verdadero milagro que se sostenga la mayoría de las Agrupaciones asturianas» ${ }^{195}$.

\subsection{LOS EFECTIVOS DE LA U.G.T.}

Por lo dicho, la cuestión de la influencia del socialismo en la evolución de las condiciones laborales del período dista de estar concluida: pero no sólo en Asturias, sino en el conjunto peninsular.

Los datos del total de afiliados a la U.G.T. permiten afirmar cierta estabilidad (o estancamiento), suponiendo naturalmente la entera fiabilidad de las cifras, que son las facilitadas por la propia Unión General (y que en sus días fueron acogidas con reticencia por determinados comentaristas -Maurín por ejemplo).

Pasan de 211.342 afiliados en 1920 a 210.567 en 1928.

Dentro de este período, se observa un alza en 1921 (240.113), seguida de inmediata regresión, y un movimiento más suave de ascenso entre 1925 y 1927 (223.396), con nuevo retroceso. No se han dado explicaciones convincentes sobre estos cambios.

Después del año 28 se aprecia ya el aumento definitivo, todavía bajo la Dictadura (esto es importante), quizás en relación con el desarrollo de los Comités Paritarios. Es la marcha ascendente que se dispara con la proclamación de la II República ${ }^{196}$.

$\mathrm{Si}$, fuera de este caso, faltan razones conocidas para enten. der la evolución cuantitativa de la U.G.T., tampoco hay, a la inversa, motivos para relacionar la evolución política de la propia Unión con su expresión cuantitativa.

No los hay, por ejemplo, para ver en las cifras algún reflejo de un hipotético desencanto de los obreros ante el relativo colaboracionismo de los socialistas con el Directorio. Sólo una asociación -el Sindicato Minero de Serón (Almería) - se da de baja por ello de la U.G.T. entre 1923 y $1928{ }^{197}$.

194 Ibidem, pág. 217.

195 Ibidem, pág. 192.

196 Cf. Sevilla: op. sit., pág. 409; Fusi: El movimiento socialista..., página 66 .

197 Cf. Unión General de Trabajadores. Convocatoria y orden del dia del XVI Congreso..., pág. 16. 
Aunque los datos son sumamente confusos, el P.S.O.E. por su parte reconoce de modo expreso haber perdido adeptos desde el golpe de Estado hasta el propio año 28. Y afirma -demostrándolo a plena satisfacción por lo que se refiere al primer hechoque «no fue la escisión comunista lo que más daño nos produjo, sino la falta de libertad y la crisis de trabajo, que nos ha arrebatado a distintas Secciones ${ }^{198}$.

La problemática se complica observando la distribución regional.

En cuanto a la U.G.T. -la mejor conocida-, lo más llamativo en ello es seguramente la clara regresión que se aprecia en la zona industrial del Norte y la pujanza levantina:

En Asturias y en 1922, cuenta, decíamos, 18.147 afiliados; en abril de 1928, 12.808. Vizcaya, 17.575 en 1922; 9.938 en 1928.

En 1922, estas dos provincias ocupan la segunda y tercera plaza en la escala de efectivos ugetistas, tras la de Madrid. En abril de 1928 continúa Madrid al frente, pero ahora seguido por Valencia, Castellón, Asturias, Alicante y Vizcaya por este orden ${ }^{199}$.

Fuera de las razones apuntadas acerca de la región asturiana, hay aquí un tema de investigación inédito.

Algo semejante ocurre con el asunto de la extracción social de los propios afiliados a la Unión General de Trabajadores.

Nada resuelve de momento, aunque es un indicio a seguir, la afirmación frecuente de que la U.G.T. se desenvuelve entonces sobre las cenizas de la C.N.T. ${ }^{200}$.

Más sugestiva es la tesis, repetida ya bajo el Directorio, de que el desarrollo (en realidad el mantenimiento) de la sindical socialista se debe a su expansión en el campo ${ }^{201}$. Enrique Santiago se defiende de ello en los mismos años. Entre 1922 y 1928, dice, el aumento de los efectivos de la U.G.T. (aunque en verdad

198 Partido Socialista Obrero Español. Convocatoria y orden del dia para el XII Congreso..., pág. 192. Los datos, según queda dicho, son confusos. El propio partido habla de 11.916 afiliados representados en el Congreso de 1921 y sólo 4.306 en el de 1927; aunque en esta fecha las asociaciones adscritas al P.S.O.E. cuentan con 7.940 (ibidem, pág. 190 ss.). Por otra parte, estas cifras difieren por completo de las que basándose en Maurín da Sevilla Andrés: op. cit., pág. 409.

199 Cf. Unión General de Trabajadores. Convocatoria y orden del día del XVI Congreso..., pág. 88.

200 Cf. Sevilla: op. cit., por ejemplo.

201 Cf. ibidem; Artola, op. cit.; Carr: op. cit. 
no hay tal) se consigue por medio de los Comités Paritarios, que precisamente se organizan por ley en todos los sectores de la producción menos en la agricultura. Entre ambas fechas, de otra parte, se disuelven 65 secciones de la Unión General, que cuen$\tan 15.000$ afiliados. $Y$ en su mayor parte son campesinos. «En diciembre de 1929 -insiste- apenas llegan a 30.000 los obreros del campo afiliados a la Unión» ${ }^{202}$.

Las cifras oficiales no corroboran por completo esta cifra; pero sí su sentido.

De 208.170 ugetistas de julio de 1922, son campesinos 65.405: es decir, 31,41 por 100. De 208.531 en abril de 1928, lo son 50.332: sólo 24,13 de cada 100 .

Siempre según sus propios datos, es forzoso concluir que el proceso de ruralización de la U.G.T. (que es indudable) parece haber avanzado antes y sobre todo después de la Dictadura; no en ella.

En 1932, de 1.041 .539 afiliados, son 445.414 agricultores: 42,76 por $100^{203}$.

En conjunto - cabe preguntarse de nuevo tras estas consideraciones-, ¿puede hablarse de signo positivo en el saldo del acercamiento del socialismo al Directorio?

Parece que, en principio, sí. El mero hecho de que se den un estancamiento global entre 1920 y 1928 y una reactivación en los últimos meses del régimen impide afirmar el fracaso.

En 1930, Araquistáin intenta explicarlo:

Después de 1923, el socialismo se replegó en su independencia $\mathrm{y}$ en sus métodos clásicos de lucha. En cierta manera, el interregno parlamentario abierto por la dictadura militar le fue fructífero, al obligarle a concentrar sus esfuerzos en la organización sindical, íntimamente unida a la política, y al alejarlo, por eclipse de toda actividad electoral,

\footnotetext{
202 Santiago: op. cit., pág. 45.

203 Cf. Unión General de Trabajadores. Convocatoria y orden del dia del XVI Congreso..., pág. 89; Unión General de Trabajadores. Memoria $y$ orden del día del XVII Congreso ordinario que se celebrará en Madrid los días 14 y siguientes de octubre de 1932, Madrid, Gráfica Socialista, 1932, pág. 60; Fusi: El movimiento socialista..., pág. 66; Edward E. Malefakis: Agrarian Reform and Peasant Revolution in Spain, Yale University Press, New Haven-London, 1970, pág. 156 (hay traducción castellana).
} 
154 EL SOCIALISMO DURANTE LA DICTADURA (1923-1930)

del republicanismo histórico. Los papeles han cambiado radicalmente. Ya no es el socialismo el impregnado de republicanismo puro, sino el republicanismo el que quiere impregnarse de socialismo, como lo indica el partido republicano radical socialista, creado en 1929. Los que hace dos años remolcaban al socialismo, ahora van a remolque de él ${ }^{204}$.

204 Luis Araquistáin: El ocaso de un régimen, Madrid, Editorial España, 19309, pág. 109. 